\title{
23. THE INORGANIC GEOCHEMICAL RECORD OF THE NORTHWEST ARABIAN SEA: A HISTORY OF PRODUCTIVITY VARIATION OVER THE LAST 400 K.Y. FROM SITES 722 AND $724^{1}$
}

\author{
Graham B. Shimmield ${ }^{2}$ and Stephen R. Mowbray ${ }^{2}$
}

\begin{abstract}
High-resolution sampling from late Pleistocene (last 400 k.y.) sediments of Site 722 (upper $16 \mathrm{~m}$ ) and Site 724 (upper $70 \mathrm{~m}$ ), and subsequent inorganic geochemical analysis, has defined the history of productivity in the northwest Arabian Sea. Eolian dust input from the Arabian Peninsula and Somalia is characterized by the record of $\mathrm{Ti} / \mathrm{Al}$ and $\mathrm{Cr} / \mathrm{Al}$. This dust record displays strong precessional periodicity (cycles at $25 \mathrm{k} . \mathrm{y}$.) suggesting the Southwest Monsoon and associated winds play a key role in transporting terrigenous material from the land. High biological productivity results in the accumulation of biogenic $\mathrm{CaCO}_{3}$ and opal in the sediments, the latter having an unexpectedly minor contribution to the total mass flux. Due to dilution of the $\mathrm{CaCO}_{3}$ record by the terrigenous component, the record of biological productivity is best exemplified by $\mathrm{Ba}$. Its record, together with that of other metals recording biological association and redox variability $(\mathrm{Cu}, \mathrm{Ni}, \mathrm{Zn}, \mathrm{V}, \mathrm{U})$ clearly identifies the interglacial episodes as being more biologically productive. The striking agreement between $\mathrm{Ba}$ and the $\delta^{18} \mathrm{O}$ record in planktonic foraminifers suggests that the supply of nutrients during these periods of high productivity is linked to ocean-wide changes in ocean fertility, and not just local upwelling conditions. High levels of phosphate accumulation in interglacial sediments is attributed to both diagenetic phosphorite formation and biogenic skeletal debris. This study provides a detailed record of productivity variation in the northwest Arabian Sea during the late Pleistocene.
\end{abstract}

\section{INTRODUCTION}

The northwest Arabian Sea has been long known as an area of active oceanic upwelling, brought about by the seasonal Southwest Monsoon (Sen Gupta et al., 1975; Rao and Jayaraman, 1970; Qasim, 1982; Slater and Kroopnick, 1984). The intensity of this wind induces Ekman transport of surface waters in the summer months and sustains high levels of biological productivity through nutrient supply from intermediate water depths. Microbial decay of the settling organic matter creates an intense oxygen minimum zone (OMZ) between depths of 200 and $1500 \mathrm{~m}$.

As significant variations in the climate of the Earth have occurred during the late Pleistocene (CLIMAP, 1976), and the Southwest Monsoon is believed to have been strongly influenced by glacial/interglacial episodes (Prell, 1984a; Prell and Kutzbach, 1987), it is likely that the sediments underlying the upwelling zone will record the history of the productivity variations driven by the Southwest Monsoon. Previous studies have used "proxy-indicators" such as the distribution of pollen types and the percentage of $G$. bulloides in sediment cores to elucidate the history of upwelling (Van Campo et al., 1982; Prell, 1984a, b; Prell and Van Campo, 1986) with some success. However, inorganic geochemistry as applied to paleoceanography and climate change pioneered in the Pacific (Adelseck and Anderson, 1978; Pedersen, 1983; Lyle et al., 1988; Pedersen et al., 1988; Finney et al., 1988) has not been applied to the northwest Indian Ocean. Surface sediment geochemistry of this area (Kolla et al., 1981; Shankar et al., 1987; Shimmield et al., 1990) has provided a geochemical framework delineating the importance of terrigenous dust inputs together with skeletal $\mathrm{CaCO}_{3}$ and minor opal accumulation in this area.

In this study we have selected two sites from the Oman Margin and performed a high-resolution study of the inorganic geo-

\footnotetext{
${ }^{1}$ Prell, W. L., Niitsuma, N., et al., 1991. Proc. ODP, Sci. Results, 117: College Station, TX (Ocean Drilling Program).

2 The Department of Geology and Geophysics, University of Edinburgh, West Mains Road, Edinburgh, EH9 3JW, Scotland, U.K.
}

chemistry recorded in the sediments accumulating over the past 400,000 yr. By using simple statistical treatment (principal component analysis) of the data we are able to define four major factors accounting for $80 \%-95 \%$ of the geochemical variation observed. Interpretation of the depth profiles of key elements, together with spectral analysis (see Weedon and Shimmield, this volume) allows an assessment of the significance of the Southwest Monsoon and changes in global climate in influencing the history of upwelling productivity.

\section{SAMPLING AND METHODS}

Two sites were selected for this high-resolution study of the inorganic chemical composition of late Pleistocene sediments. These represent depositional conditions on the Owen Ridge below the present position of the OMZ (Site 722) in $2028 \mathrm{~m}$ of water, and within the OMZ on the Oman continental margin (Site 724 ) in $593 \mathrm{~m}$ of water (Fig. 1). At both sites only the upper (I) lithologic unit was sampled which was composed of foraminifer-bearing nannofossil ooze $(5 \%-25 \%$ foraminifers) at Site 722 , and calcareous clayey silt with $5 \%+$ foraminifers at Site 724 . Over the depth intervals studied here $(0-15 \mathrm{mbsf}$, Hole 722B; 0 $68 \mathrm{mbsf}$, Hole $724 \mathrm{C}$ ), the sedimentary sequence is essentially homogeneous with respect to mineralogical composition and sedimentary structures. No evidence of slumped horizons, or mass flow deposits are noted (Shipboard Scientific Party, 1989a, b) and the units sampled were undisturbed by gas expansion voids.

On vertical sectioning of the cores, $20 \mathrm{~cm}^{3}$ plugs were taken at $20 \mathrm{~cm}$ intervals from both holes, and sealed in polyethylene bags. On arrival at Edinburgh the samples were stored at $4^{\circ} \mathrm{C}$ prior to processing. Water contents were measured by weight loss on drying at $60^{\circ} \mathrm{C}$. Using an average grain density of $2.6 \mathrm{~g}$ $\mathrm{cm}^{-3}$ (Shipboard Scientific Party, 1989a, b), dry bulk density values were calculated for use in flux calculations. In addition, sea salt concentrations were estimated assuming a pore water salinity equivalent to normal seawater. All chemical data presented here are corrected for sea salt dilution (and contribution in the case of $\mathrm{Mg}$ and $\mathrm{Ca}$ ).

The bulk sediment samples were ground in a tungsten carbide Tema mill and prepared for X-ray fluorescence spectrome- 


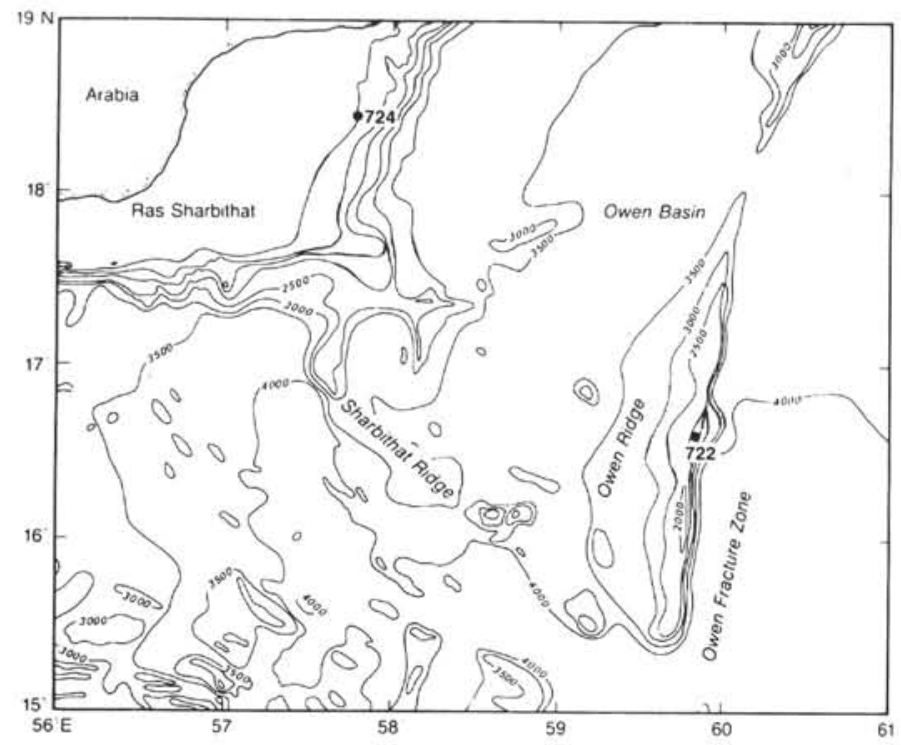

Figure 1. Location of Sites 722 and 724 in the northwest Arabian Sea.

try (XRF). This involved the fusion of the sediment powder into a glass disc using lithium tetraborate and $\mathrm{La}$ as a heavy absorber (Norrish and Hutton, 1969) for major elements, and pressing the powder into a briquette with boric acid backing for minor elements (Shimmield, 1985). The XRF analysis was performed on a Phillips PW1250 sequential automatic X-ray spectrometer. International rock standards were used for calibration. The precision and accuracy of the method are given in Table 1. For U and Th data, $\alpha$-spectrometry was performed on total dissolution of the sample using isotope dilution. The extremely precise methodology is reflected in the presentation of data to two significant figures (for further details see Shimmield and Mowbray, this volume).

\section{RESULTS AND DISCUSSION}

The bulk chemical data obtained from the late Pleistocene sediments in Holes 722B and 724C are given in Appendixes A-C. Major element data are presented for both holes. At Site 722 we also present minor element data, providing a detailed geochemical record over the last 365 k.y. Appendix D presents minimum, average, and maximum major element values and trace element values for Holes 722B and minimum, average, and maximum major element value for Hole $724 \mathrm{C}$. Late Pleistocene/Holocene stratigraphy is provided by the $\delta^{18} \mathrm{O}$ record of planktonic foraminifers, courtesy of Prell et al. (this volume) and Pedersen and Zahn (this volume) for Holes 722B and 724C, respectively (Fig. 2). Age assignments are based on the correlation of the $\delta^{18} \mathrm{O}$ curve with the SPECMAP stack (Imbrie et al., 1984). The age models from these authors were also used to generate linear sedimentation rates from which we calculate mass accumulation rates based on our dry bulk density values.

In the Arabian Sea, the bulk sediment composition is controlled by both lithogenic and biogenic input, with virtually no hydrothermal component (Shankar et al., 1987; Shimmield, et al., 1990). Consequently, these data are presented as element-toaluminum ratios in order to examine fluctuations in the chemistry of the aluminosilicate component that are not due to variations in the biogenic component.

In order to examine the first-order relationships and controls on the geochemical composition of the Pleistocene sediments, statistical analysis of the complete dataset on both holes has been performed. Table 2 presents the results of inter-element correlation, while Table 3 indicates the results of principal com-
Table 1. XRF and $\alpha$-spectrometry analytical precision and accuracy for major and minor elements.

\begin{tabular}{lcccc}
\hline Element & $\begin{array}{c}\text { Mean } \\
(\mathrm{n}=8)\end{array}$ & $1 \sigma$ & $\begin{array}{c}\text { Estimated total precision } \\
\text { (as \% rel. std. dev., 1 })\end{array}$ & Accuracy $^{\mathrm{b}}$ \\
\hline $\mathrm{Si}$ & 26.24 & 0.12 & 0.5 & 0.097 \\
$\mathrm{Al}$ & 7.99 & 0.03 & 0.4 & 0.075 \\
$\mathrm{Fe}$ & 5.29 & 0.03 & 0.6 & 0.032 \\
$\mathrm{Ca}$ & 1.14 & 0.01 & 1.0 & 0.048 \\
$\mathrm{~K}$ & 2.39 & 0.01 & 0.4 & 0.019 \\
$\mathrm{Ti}$ & 0.45 & 0.004 & 1.0 & 0.009 \\
$\mathrm{Mn}$ & 2.15 & 0.02 & 0.7 & 0.004 \\
$\mathrm{P}$ & 0.10 & 0.002 & 2.0 & 0.013 \\
$\mathrm{Ba}$ & 2736 & 36.83 & 1.3 & 42.5 \\
$\mathrm{Ce}$ & 73 & 1.20 & 1.6 & 13.5 \\
$\mathrm{Cr}$ & 107 & 1.83 & 1.7 & 14.4 \\
$\mathrm{Cu}$ & 112 & 0.83 & 0.7 & 4.7 \\
$\mathrm{Nd}$ & 34 & 0.90 & 2.6 & 3.6 \\
$\mathrm{Ni}$ & 120 & 0.71 & 0.6 & 4.7 \\
$\mathrm{Rb}$ & 80 & 0.43 & 0.5 & 3.8 \\
$\mathrm{Sr}$ & 400 & 3.77 & 0.9 & 10.7 \\
$\mathrm{~V}$ & 114 & 2.11 & 1.8 & 10.8 \\
$\mathrm{Y}$ & 30 & 0.43 & 1.4 & 3.8 \\
$\mathrm{Zn}$ & 193 & 0.99 & 0.5 & 6.1 \\
$\mathrm{Zr}$ & 126 & 1.12 & 0.9 & 7.2 \\
\hline
\end{tabular}

$\alpha$-Spectrometry Analytical Precision and Accuracy

\begin{tabular}{ccccc}
\hline Element & $\begin{array}{c}\text { Mean }^{\mathrm{c}} \\
(\mathrm{n}=6)\end{array}$ & $1 \sigma$ & $\%$ r.s.d. & Accuracy \\
\hline U & 2.73 & 0.17 & 6.2 & 0.05 \\
Th & 9.22 & 0.33 & 3.6 & 0.05 \\
\hline
\end{tabular}

Major element mean concentrations and accuracy in wt. \%, minor elements in ppm.

a Total precision includes counting error, disc reproducibility, error in regression line, and error in matrix mass absorption determinations.

b Accuracy determined from r.m.s.d. of international standards about the regression line.

c Mean concentration and accuracy expressed in ppm.

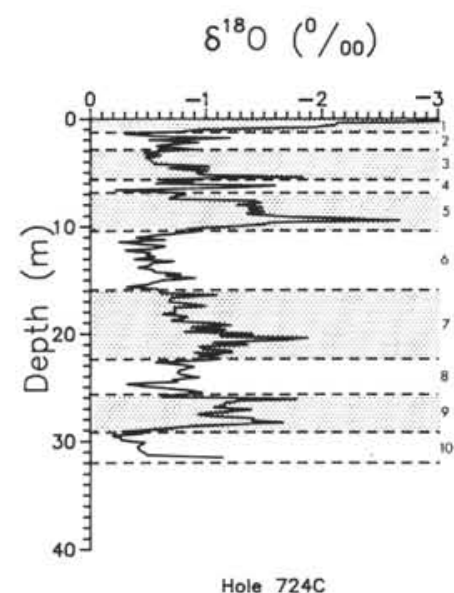

G. ruber
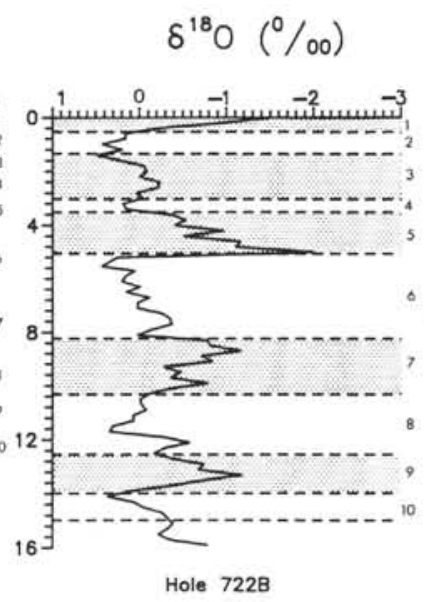

G. sacoulifer
Figure 2. Oxygen isotope stratigraphy for Hole 724C (Zahn and Pedersen, this volume) and Hole 722B (Clemens and Prell, this volume). Isotope stages assigned by matching to the SPECMAP stack (Imbrie et al., 1984). In this, and following figures, odd numbered interglacial stages are shaded.

ponent analysis (a data reduction technique for identifying a small set of variables that account for a large proportion of the total variance in the original variables). In Table 3 it is apparent that the first three eigenvalues (i.e., the variance of the principal components) account for $94.6 \%$ of the total variance in major element composition for Hole $724 \mathrm{~B}$, and $80.4 \%$ of the total 
Table 2. Correlation matrix, Holes 722B and 724C.

\begin{tabular}{|c|c|c|c|c|c|c|c|c|c|c|c|c|c|c|c|c|c|c|c|c|}
\hline \multicolumn{21}{|c|}{ Hole $722 \mathrm{~B}$} \\
\hline & $\mathrm{Si}$ & Al & $\mathrm{Fe}$ & $\mathrm{Ti}$ & $\mathrm{Mn}$ & $P$ & $\mathrm{Ca}$ & $\mathrm{Ni}$ & $\mathrm{Cr}$ & $\mathrm{v}$ & $\mathrm{Cu}$ & $\mathrm{Zn}$ & $\mathrm{Sr}$ & $\mathrm{Rb}$ & $\mathrm{Zr}$ & Ba & $\mathrm{Ce}$ & $\mathrm{Nd}$ & $\mathrm{Y}$ & u \\
\hline Al & 0.979 & & & & & & & & & & & & & & & & & & & \\
\hline $\mathrm{Fe}$ & 0.964 & 0.979 & & & & & & & & & & & & & & & & & & \\
\hline $\mathrm{Ti}$ & -0.969 & -0.955 & -0.954 & & & & & & & & & & & & & & & & & \\
\hline $\mathrm{Mn}$ & 0.982 & 0.993 & 0.976 & -0.958 & & & & & & & & & & & & & & & & \\
\hline $\mathbf{P}$ & 0.839 & 0.852 & 0.834 & -0.792 & 0.849 & & & & & & & & & & & & & & & \\
\hline $\mathrm{Ca}$ & 0.540 & 0.538 & 0.567 & -0.515 & 0.560 & 0.450 & & & & & & & & & & & & & & \\
\hline $\mathrm{Ni}$ & 0.836 & 0.830 & 0.856 & -0.812 & 0.834 & 0.668 & 0.514 & & & & & & & & & & & & & \\
\hline $\mathrm{Cr}$ & 0.910 & 0.904 & 0.911 & -0.880 & 0.917 & 0.721 & 0.557 & 0.863 & & & & & & & & & & & & \\
\hline v & 0.828 & 0.843 & 0.836 & -0.777 & 0.823 & 0.691 & 0.408 & 0.827 & 0.857 & & & & & & & & & & & \\
\hline $\mathrm{Cu}$ & -0.081 & -0.056 & -0.051 & 0.169 & -0.071 & -0.170 & 0.031 & 0.197 & 0.121 & 0.241 & & & & & & & & & & \\
\hline $\mathrm{Zn}$ & 0.623 & 0.617 & 0.609 & -0.573 & 0.604 & 0.457 & 0.337 & 0.737 & 0.680 & 0.735 & 0.446 & & & & & & & & & \\
\hline $\mathrm{Sr}$ & -0.787 & -0.768 & -0.771 & 0.821 & -0.786 & -0.700 & -0.425 & -0.527 & -0.640 & -0.495 & 0.267 & -0.348 & & & & & & & & \\
\hline $\mathrm{Rb}$ & 0.918 & 0.940 & 0.927 & -0.879 & 0.924 & 0.754 & 0.505 & 0.850 & 0.939 & 0.919 & 0.126 & 0.707 & -0.602 & & & & & & & \\
\hline $\mathrm{Zr}$ & 0.788 & 0.797 & 0.786 & -0.731 & 0.803 & 0.627 & 0.480 & 0.740 & 0.881 & 0.805 & 0.126 & 0.585 & -0.379 & 0.882 & & & & & & \\
\hline $\mathrm{Ba}$ & -0.499 & -0.545 & -0.520 & 0.521 & -0.556 & -0.533 & -0.343 & -0.234 & -0.432 & -0.256 & 0.426 & 0.052 & 0.429 & -0.466 & -0.496 & & & & & \\
\hline $\mathrm{Ce}$ & 0.568 & 0.573 & 0.583 & -0.562 & 0.560 & 0.415 & 0.316 & 0.574 & 0.607 & 0.592 & 0.079 & 0.393 & -0.372 & 0.628 & 0.539 & -0.238 & & & & \\
\hline Nd & 0.241 & 0.234 & 0.232 & -0.203 & 0.222 & 0.074 & 0.143 & 0.347 & 0.305 & 0.335 & 0.269 & 0.337 & -0.018 & 0.347 & 0.297 & 0.047 & 0.509 & & & \\
\hline $\mathrm{Y}$ & 0.529 & 0.560 & 0.561 & -0.457 & 0.539 & 0.297 & 0.317 & 0.681 & 0.662 & 0.774 & 0.522 & 0.718 & -0.143 & 0.712 & 0.672 & 0.026 & 0.472 & 0.469 & & \\
\hline U & 0.015 & 0.010 & 0.020 & -0.029 & 0.018 & -0.036 & -0.004 & 0.083 & 0.066 & 0.089 & 0.240 & 0.083 & -0.005 & 0.030 & 0.072 & 0.218 & 0.071 & -0.002 & 0.191 & \\
\hline Th & 0.645 & 0.647 & 0.692 & -0.646 & 0.651 & 0.592 & 0.392 & 0.676 & 0.667 & 0.636 & 0.025 & 0.396 & -0.361 & 0.648 & 0.621 & -0.409 & 0.471 & 0.177 & 0.354 & -0.059 \\
\hline
\end{tabular}

Hole $724 \mathrm{C}$

\begin{tabular}{|c|c|c|c|c|c|c|c|c|}
\hline & $\mathrm{Si}$ & Al & $\mathrm{Fe}$ & $\mathrm{Mg}$ & $\mathrm{Ca}$ & $\mathrm{K}$ & $\mathrm{Ti}$ & $\mathrm{Mn}$ \\
\hline Al & 0.908 & & & & & & & \\
\hline $\mathrm{Fe}$ & 0.782 & 0.960 & & & & & & \\
\hline $\mathrm{Mg}$ & 0.785 & 0.882 & 0.888 & & & & & \\
\hline $\mathrm{Ca}$ & -0.871 & -0.899 & -0.853 & -0.825 & & & & \\
\hline $\mathbf{K}$ & 0.901 & 0.984 & 0.954 & 0.926 & -0.904 & & & \\
\hline $\mathrm{Ti}$ & 0.933 & 0.971 & 0.923 & 0.882 & -0.906 & 0.969 & & \\
\hline $\mathrm{Mn}$ & 0.832 & 0.866 & 0.837 & 0.858 & -0.790 & 0.879 & 0.878 & \\
\hline P & -0.382 & -0.451 & -0.476 & -0.520 & 0.374 & -0.491 & -0.465 & -0.521 \\
\hline
\end{tabular}


Table 3. Eigenanalysis of correlation matrix of Holes $722 B$ and $724 C$.

\begin{tabular}{|c|c|c|c|c|c|c|}
\hline \multicolumn{7}{|c|}{ Hole 722B } \\
\hline Eigenvalue & 12.354 & 3.640 & 1.099 & 0.835 & 0.766 & 0.533 \\
\hline Proportion & 0.588 & 0.173 & 0.052 & 0.040 & 0.036 & 0.025 \\
\hline Cumulative & 0.588 & 0.762 & 0.814 & 0.854 & 0.890 & 0.916 \\
\hline Variable & PC1 & $\mathrm{PC} 2$ & PC3 & PC4 & PC5 & PC6 \\
\hline $\mathrm{Si}$ & 0.273 & 0.111 & 0.046 & 0.002 & -0.057 & -0.139 \\
\hline Al & 0.274 & 0.105 & 0.051 & -0.005 & -0.084 & -0.141 \\
\hline $\mathrm{Fe}$ & 0.275 & 0.087 & 0.037 & 0.002 & 0.021 & -0.019 \\
\hline $\mathrm{Ti}$ & -0.266 & -0.138 & -0.057 & -0.034 & 0.076 & 0.110 \\
\hline Mn & 0.272 & 0.127 & 0.054 & 0.009 & -0.032 & -0.139 \\
\hline $\mathrm{P}$ & 0.216 & 0.209 & 0.149 & -0.140 & -0.071 & 0.068 \\
\hline $\mathrm{Ca}$ & 0.153 & 0.106 & -0.146 & 0.054 & 0.892 & -0.012 \\
\hline $\mathrm{Ni}$ & 0.259 & -0.154 & 0.007 & -0.130 & 0.113 & 0.092 \\
\hline $\mathrm{Cr}$ & 0.275 & -0.052 & -0.035 & 0.055 & 0.019 & -0.022 \\
\hline V & 0.259 & -0.138 & 0.068 & -0.035 & -0.200 & 0.076 \\
\hline $\mathrm{Cu}$ & 0.031 & -0.437 & 0.178 & -0.231 & 0.160 & 0.004 \\
\hline $\mathrm{Zn}$ & 0.172 & -0.274 & 0.090 & -0.474 & 0.020 & -0.200 \\
\hline $\mathrm{Sr}$ & -0.121 & -0.419 & -0.260 & -0.031 & 0.081 & 0.040 \\
\hline $\mathrm{Rb}$ & 0.276 & -0.081 & -0.046 & 0.000 & -0.084 & -0.073 \\
\hline $\mathrm{Zr}$ & 0.270 & -0.119 & -0.076 & 0.032 & 0.008 & -0.091 \\
\hline $\mathrm{Ba}$ & -0.150 & -0.342 & 0.214 & -0.094 & -0.108 & 0.132 \\
\hline $\mathrm{Ce}$ & 0.207 & -0.108 & -0.131 & 0.448 & -0.195 & 0.290 \\
\hline $\mathrm{Nd}$ & 0.115 & -0.304 & -0.398 & 0.439 & -0.004 & 0.004 \\
\hline Y & 0.189 & -0.351 & -0.013 & 0.021 & -0.030 & -0.166 \\
\hline U & -0.006 & -0.158 & 0.775 & 0.477 & 0.190 & 0.011 \\
\hline Th & 0.203 & 0.051 & 0.032 & -0.212 & 0.055 & 0.851 \\
\hline \multicolumn{7}{|c|}{ Hole $724 \mathrm{C}$} \\
\hline Eigenvalue & 7.658 & 1.068 & 0.566 & 0.235 & 0.201 & 0.134 \\
\hline Proportion & 0.766 & 0.107 & 0.057 & 0.023 & 0.020 & 0.013 \\
\hline Cumulative & 0.766 & 0.873 & 0.929 & 0.953 & 0.973 & 0.986 \\
\hline Variable & $\mathrm{PCl}$ & $\mathrm{PC} 2$ & $\mathrm{PC} 3$ & PC4 & PC5 & PC6 \\
\hline $\mathrm{Si}$ & -0.334 & -0.169 & -0.002 & -0.634 & 0.027 & 0.102 \\
\hline $\mathrm{Al}$ & -0.354 & -0.025 & 0.122 & 0.047 & -0.151 & 0.355 \\
\hline $\mathrm{Fe}$ & -0.341 & 0.086 & 0.179 & 0.456 & -0.185 & 0.362 \\
\hline $\mathrm{Mg}$ & -0.336 & 0.083 & -0.003 & 0.495 & 0.267 & -0.495 \\
\hline $\mathrm{Ca}$ & 0.333 & 0.089 & -0.175 & 0.202 & 0.452 & 0.661 \\
\hline $\mathrm{Na}$ & -0.162 & -0.733 & -0.618 & 0.177 & 0.034 & 0.025 \\
\hline K & -0.357 & 0.017 & 0.092 & 0.107 & -0.085 & 0.109 \\
\hline $\mathrm{Ti}$ & -0.354 & -0.026 & 0.087 & -0.138 & -0.082 & 0.194 \\
\hline $\mathrm{Mn}$ & -0.329 & 0.125 & 0.037 & -0.180 & 0.784 & -0.030 \\
\hline $\mathrm{P}$ & 0.189 & -0.628 & 0.723 & 0.092 & 0.191 & -0.005 \\
\hline
\end{tabular}

variance for major, minor, and trace element data in Hole 722B. In Figures 3 and 4 the principal component scores of the compositional data are plotted on the first two, and on the first and third, principal components (cf., Li, 1982). According to Figures 3 and 4 , the geochemical data broadly define four major phase associations; (1) aluminosilicate detritus ( $\mathrm{Al}, \mathrm{K}, \mathrm{Fe}, \mathrm{Rb}$, $\mathrm{Th}, \mathrm{Ti}, \mathrm{Cr}, \mathrm{Zr}, \mathrm{V})$, (2) biogenic carbonate $(\mathrm{Ca}, \mathrm{Sr}),(3)$ organic matter $(\mathrm{Ba}, \mathrm{Cu}, \mathrm{U})$, and (4) phosphatic material (P, Y, Ce, Nd). The remaining elements $(\mathrm{Si}, \mathrm{Mn}, \mathrm{Cu}, \mathrm{Ni}, \mathrm{Zn}$ ) show relationships with both biogenic and lithogenic sources. We will now describe the distribution of the elements in detail, and account for their association.

\section{Aluminosilicate Detritus Factor}

The characteristic element defining this phase group is $\mathrm{Al}$ which is principally derived from aluminosilicate clay minerals. These clay minerals may be of terrestrial origin, or from alteration of oceanic basalts and/or hydrothermal exhalations (McMurtry and Yeh, 1981; Bonatti et al., 1983; Shankar et al., 1987; Nath et al., 1989). From studies on the distribution of sediment type on the Oman continental margin (Shimmield et al., 1989; Sirocko and Sarnthein, 1989) we consider that Al may be used as an exclusive indicator of clay detritus of continental terrigenous origin.
Preliminary results (Shipboard Scientific Party, 1989a, b) and Debrebant (this volume) indicate that illite and chlorite (and kaolinite?) with minor amounts of palygorskite form the dominant clay mineralogy. Kolla et al. (1981) have shown that palygorskite and illite are rather ubiquitous in the northwest Arabian Sea being deposited via eolian transport, the former originating in soils of the Arabian Peninsula and Somalia. From the preliminary principal component analysis we note the close association of $\mathrm{Fe}, \mathrm{K}, \mathrm{Rb}, \mathrm{Th}, \mathrm{Zr}, \mathrm{V}, \mathrm{Ti}$, and $\mathrm{Cr}$ with $\mathrm{Al}$. This composition of the aluminosilicate detritus, but also suggest how this composition may have varied with time (see discussion below). The $\mathrm{Fe}, \mathrm{K}, \mathrm{Rb}$, and $\mathrm{Th}$ content of the terrigenous component is rather constant over the depth sampled (Figs. 5 and 6) being strongly controlled by the illite/chlorite mineralogy (Boyle, 1983; Shankar et al., 1987). This agrees well with the rather uniform $\mathrm{K}$ and Th results and interpretation obtained by the downhole logging of Unit I (Shipboard Scientific Party, 1989a, b). $\mathrm{The} \mathrm{Zr} / \mathrm{Al}$ profile indicates strong spikes corresponding to similar excursions in the $\mathrm{Ti} / \mathrm{Al}$ and $\mathrm{Cr} / \mathrm{Al}$ profiles. We interpret these as concentrations of heavy minerals (see below). V/Al displays a depth profile in Hole 722B that suggests elevated $\mathrm{V}$ content within interglacial stages (particularly 1, 5, and 7). While, there is a first-order association with aluminosilicate detritus, V may well be concentrated in the sediment during periods of high organic matter flux via redox processes (Bonatti et al., 1971; 

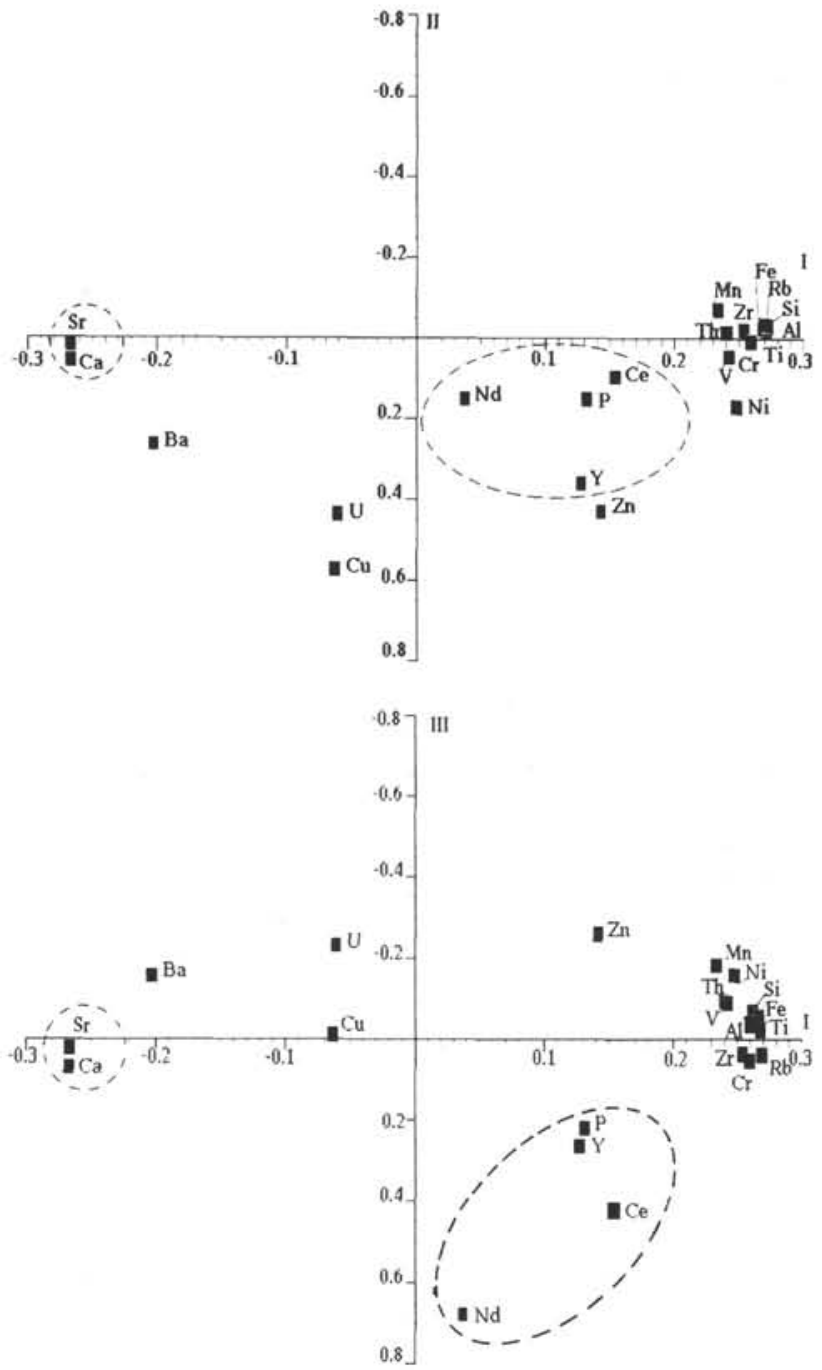

Figure 3. Plots of the principal component factors 1 vs. 2 and factors 1 vs. 3 for Hole $722 \mathrm{~B}$.

Thomson et al., 1987). We address this point further below. However, the detailed variation in $\mathrm{Ti} / \mathrm{Al}$ and $\mathrm{Cr} / \mathrm{Al}$ bears close examination. It is clear from Figure 5 that both elements in the aluminosilicate detritus covary to a high degree $(\mathrm{Cr}$ : $\mathrm{Ti}$ correlation of 0.931 ) and that a high frequency oscillation is present. This downcore variation is not related to glacial/interglacial cycles in a simple way (glacial stages are shaded in Fig. 5). By the use of fast Fourier transform (FFT) spectral analysis (see Weedon and Shimmield, this volume, for details) we have resolved the major oscillation component into a 25 k.y. cycle for both $\mathrm{Ti} / \mathrm{Al}$ and $\mathrm{Cr} / \mathrm{Al}$ in Hole 722B (using the age model of Prell et al., this volume) shown in Figure 7. $\mathrm{Ti} / \mathrm{Al}$ also responds to minor 100 k.y. and 41 k.y. forcing. However, the dominant periodicity at the precession band suggests that an important influence on $\mathrm{Ti}$ / $\mathrm{Al}$ and $\mathrm{Cr} / \mathrm{Al}$ variation is the Southwest Monsoon by analogy with other proxy-indicators that have been shown to display similar forcing (Prell and Kutzbach, 1987).

To evaluate more fully the signal contained in the $\mathrm{Ti}$ and $\mathrm{Cr}$ ratios, we must assess their geochemical pathway. $\mathrm{Ti}$ is known to be preferentially concentrated in coarser sediment fractions (Spears and Kanaris-Sotiriou, 1976; Schmitz, 1987) due to its incorporation into heavy minerals such as ilmenite, rutile, tita-

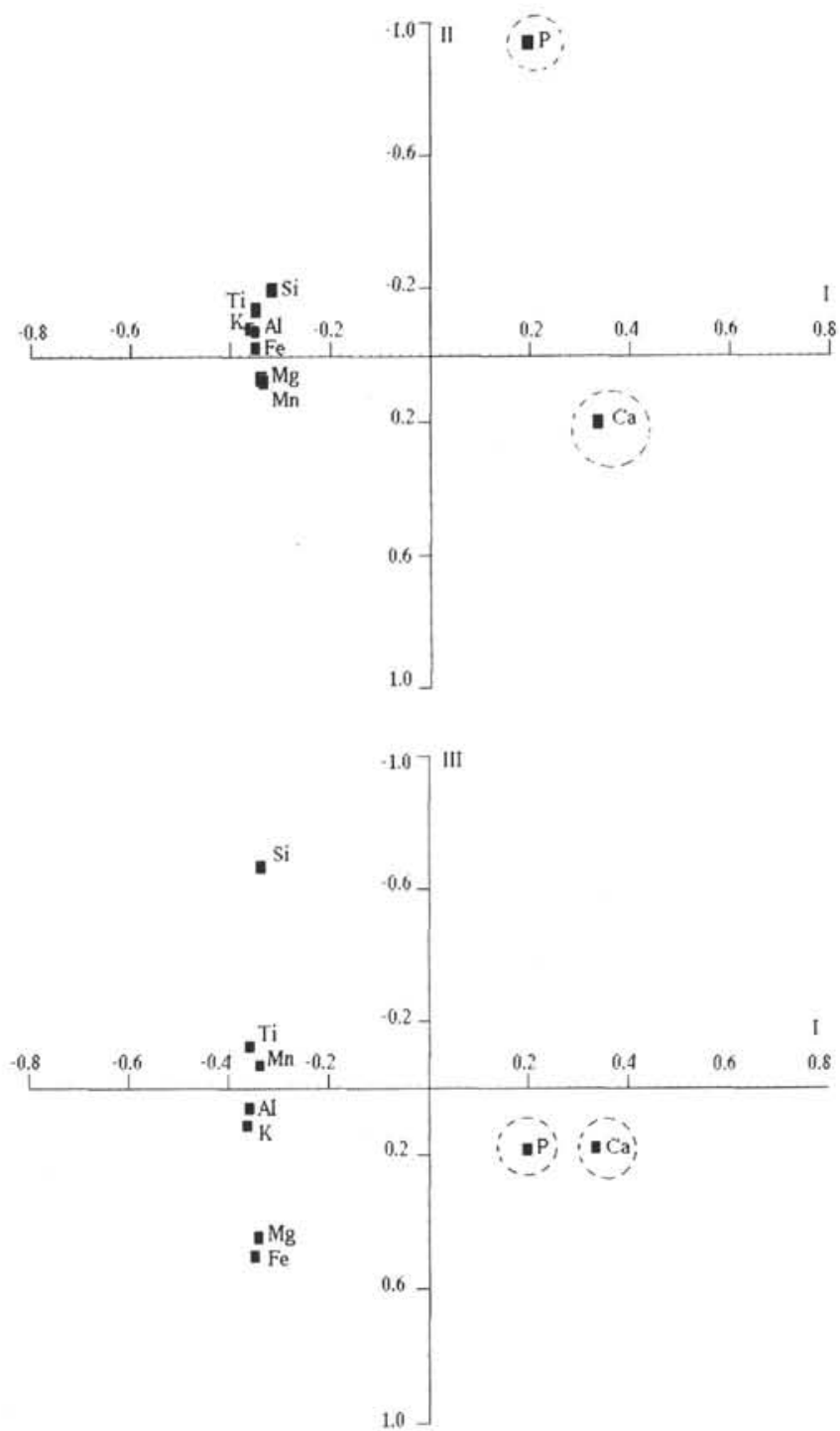

Figure 4. Plots of the principal component factors 1 vs. 2 and factors 1 vs. 3 for Hole $724 \mathrm{C}$.

nomagnetite, and augite. $\mathrm{Cr}$ is an important minor element constituent of the ultrabasic rocks making up the serpentinites of the Oman ophiolite on the Arabian Peninsula and nearby Masirah Island (Moseley and Abbotts, 1979). It is proposed that the variation in ratio observed downcore may result from changes in wind intensity (and possible small changes in direction) affecting the aerodynamics of the heavy mineral transport. This situation is most likely at Site 722 on the crest of the Owen Ridge where downslope sediment transport and variations in fluvial runoff are much less likely. Boyle (1983) pioneered the use of $\mathrm{Ti} / \mathrm{Al}$ as an indicator of climate change from his work on sediment accumulation under the Peru Current. He proposed that $\mathrm{Ti} / \mathrm{Al}$ fluctuations could be attributed to changes in the intensity of eolian transport associated with glacial/interglacial cycles. From our results presented here, and the studies of these earlier workers, we interpret the oscillation in $\mathrm{Ti} / \mathrm{Al}$ (and $\mathrm{Cr}$ / $\mathrm{Al}$ ) as a direct indicator of monsoon strength over the late Pleistocene, and that the dominant $25 \mathrm{k}$.y. precession cycle plays an important role. 


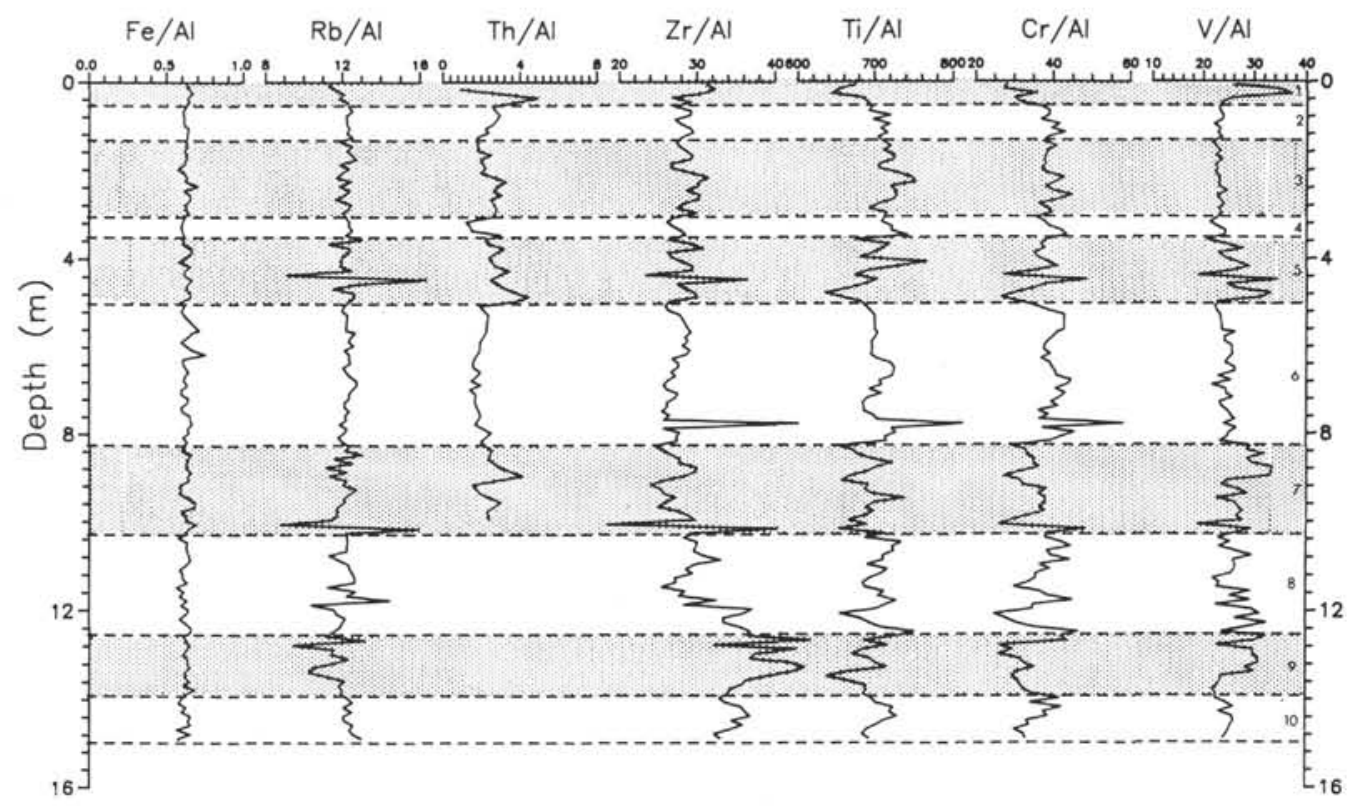

Figure 5. Element-to-Al weight ratios comprising the aluminosilicate detritus factor with depth in Hole $722 \mathrm{~B}$. All ratios except $\mathrm{Fe} / \mathrm{Al}$ are $\times 10^{-4}$.

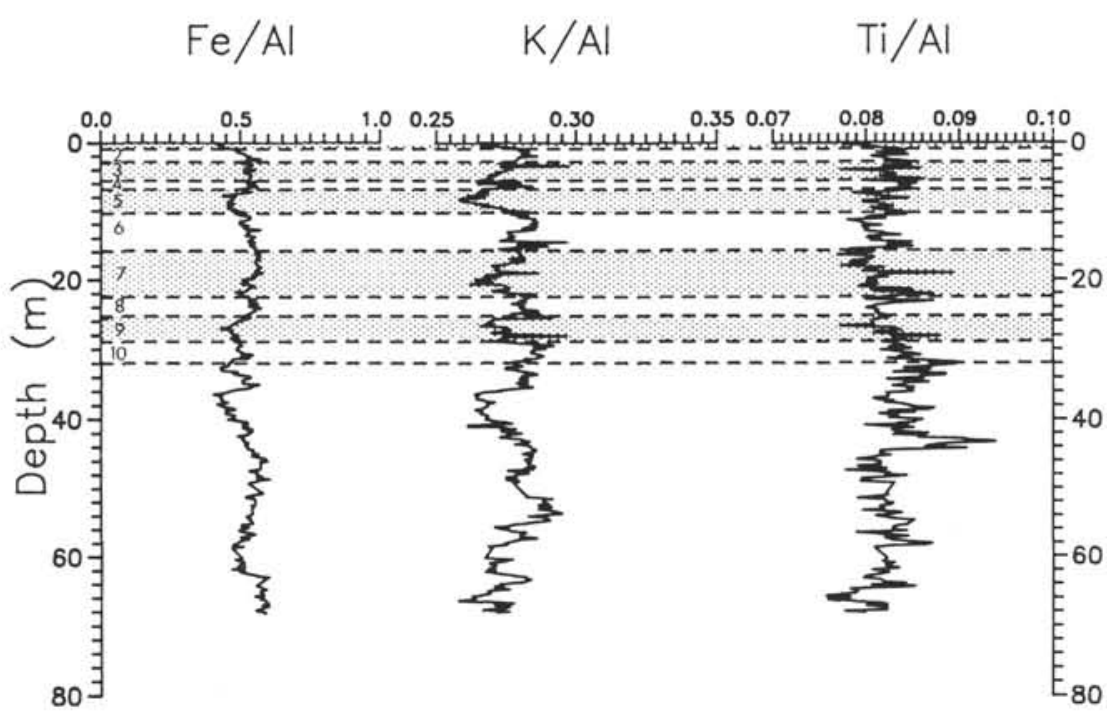

Figure 6. Element-to-Al weight ratios comprising the aluminosilicate detritus factor with depth in Hole $724 \mathrm{C}$.

\section{The Biogenic Component}

The calcareous biogenic component at Sites 722 and 724 can be identified by both the total $\mathrm{Ca}$ and $\mathrm{Sr}$ XRF analysis. We have calculated the $\mathrm{CaCO}_{3}$ content of the sediment samples by subtracting an aluminosilicate $\mathrm{Ca}$ component (in proportion to the amount of $\mathrm{Al}$ present) and converting the excess $\mathrm{Ca}$ to $\mathrm{CaCO}_{3}$. Thus,

$$
\mathrm{CaCO}_{3}=2.5\left(\mathrm{Ca}_{\text {tot }}-\left(\mathrm{Ca} / \mathrm{Al}_{\text {clay }} \times \mathrm{Al}_{\text {tot }}\right)\right)
$$

where $\mathrm{Ca} / \mathrm{Al}_{\text {clay }}$ is taken as 0.345 (Turekian and Wedepohl, 1961). This method is in error at very low $\mathrm{CaCO}_{3}$ contents due to un- certainties in the aluminosilicate ratio, but is unrivalled in precision at the $50 \%-80 \% \mathrm{CaCO}_{3}$ level found at these two sites. However, the method cannot distinguish between $\mathrm{CaCO}_{3}$ of insitu marine biogenic origin and detrital $\mathrm{CaCO}_{3}$ from the Arabian Peninsula.

Examination of the downcore record of $\mathrm{CaCO}_{3}$ in Holes 722B and $724 \mathrm{C}$ (Fig. 8) reveals that the highest mean $\mathrm{CaCO}_{3}$ content is found at the ridge site, and that interglacial periods generally have higher concentration levels. It is tempting to conclude that carbonate productivity variations are responsible and that interglacial periods were therefore more productive, but consideration of sediment mass accumulation rate (MAR) is important here. Figure 8 displays the MAR for both holes together with 

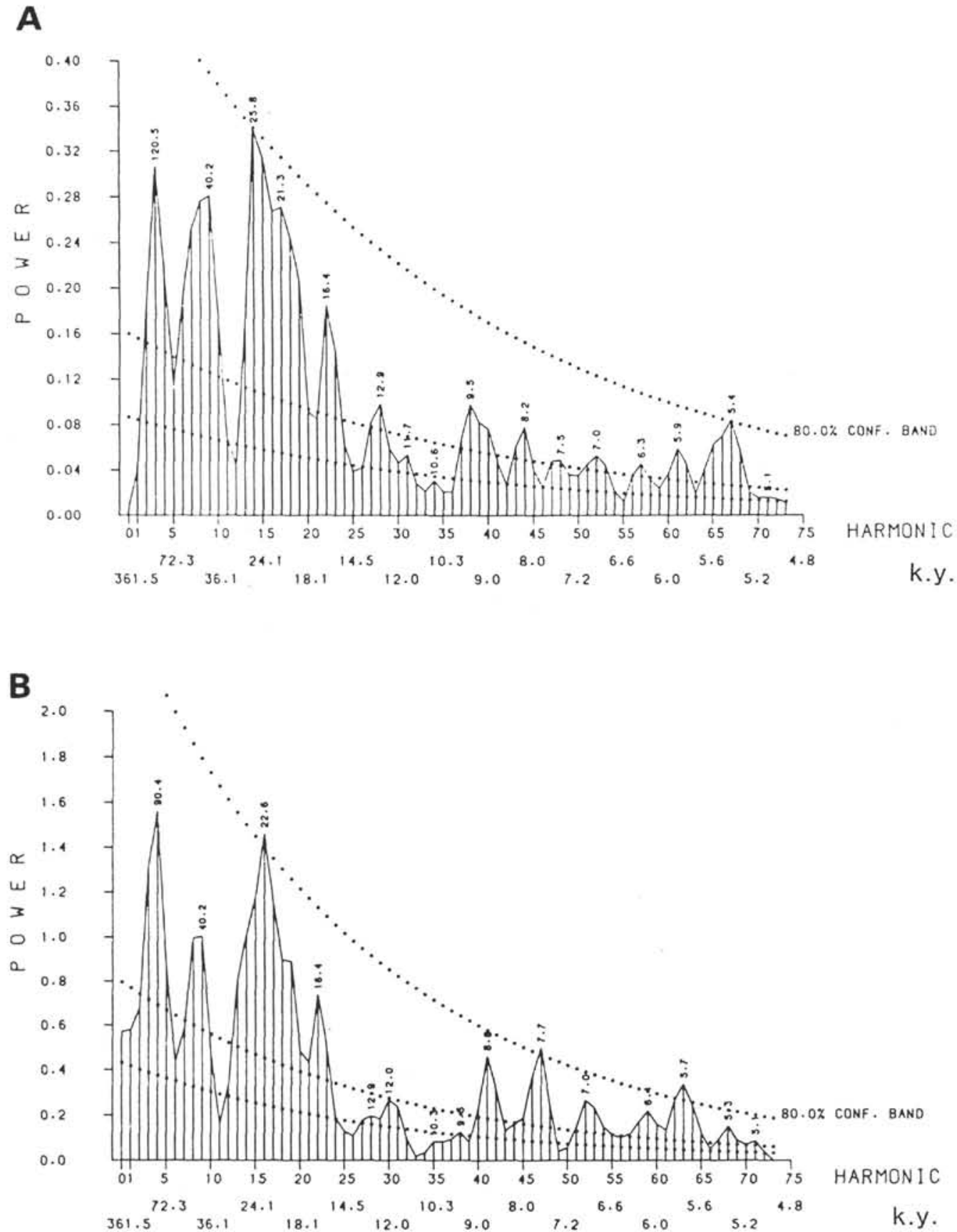

Figure 7. Periodograms for Hole 722B. A. Ti/Al. B. Cr/Al.

the $\mathrm{CaCO}_{3}$ and terrigenous $\left(1-\mathrm{CaCO}_{3}\right)$ content, indicating that the terrigenous component dominates the overall MAR and therefore dilutes the $\mathrm{CaCO}_{3}$ signal antithetically. Higher MAR's occur during glacial possibly as a result of changes in sea level and/or aridity and runoff. In order to identify changes in ocean productivity, through mechanisms such as upwelling, we require a geochemical indicator which would preserve this signal despite dilution by terrigenous material and variation in $\mathrm{CaCO}_{3}$ dissolution on the seafloor, and preferably with a large dynamic range (see below).

$\mathrm{Sr}$ is very closely correlated with $\mathrm{Ca}(\mathrm{Sr}: \mathrm{Ca}=0.947$, Table 1) in Hole 722B. This is unsurprising as seawater $\mathrm{Sr}$ is known to be incorporated into the tests of marine organisms during growth
(Table 3). However, the Sr/Ca ratio on the Owen Ridge (Fig. 9) is somewhat higher that has previously been reported and displays an interesting history. Figure 9 displays the close, but damped or modulated, trend of $\mathrm{Sr} / \mathrm{Ca}$ in comparison with the $\delta^{18} \mathrm{O}$ curve. Elevated $\mathrm{Sr}$ contents reflect a more negative (heavier) $\delta^{18} \mathrm{O}$ signal in the planktonic foraminifer (Globigerinoides sacculifer) corresponding to interglacial stages. Perhaps the $\mathrm{Sr}$ content of the biogenic $\mathrm{CaCO}_{3}$ is reflecting a temperature or species or vital effect control. We do not believe diagenetic overprinting (Baker et al., 1982) is responsible due to the shallow depth of this core. In addition, marine barite is known to contain $\mathrm{Sr}$ (0.2-3.4 mol\%; Church, 1979), but the Ba record in Hole 722B (Fig. 11) is unable to account for the $\mathrm{Sr} / \mathrm{Ca}$ shown in Figure 9. 


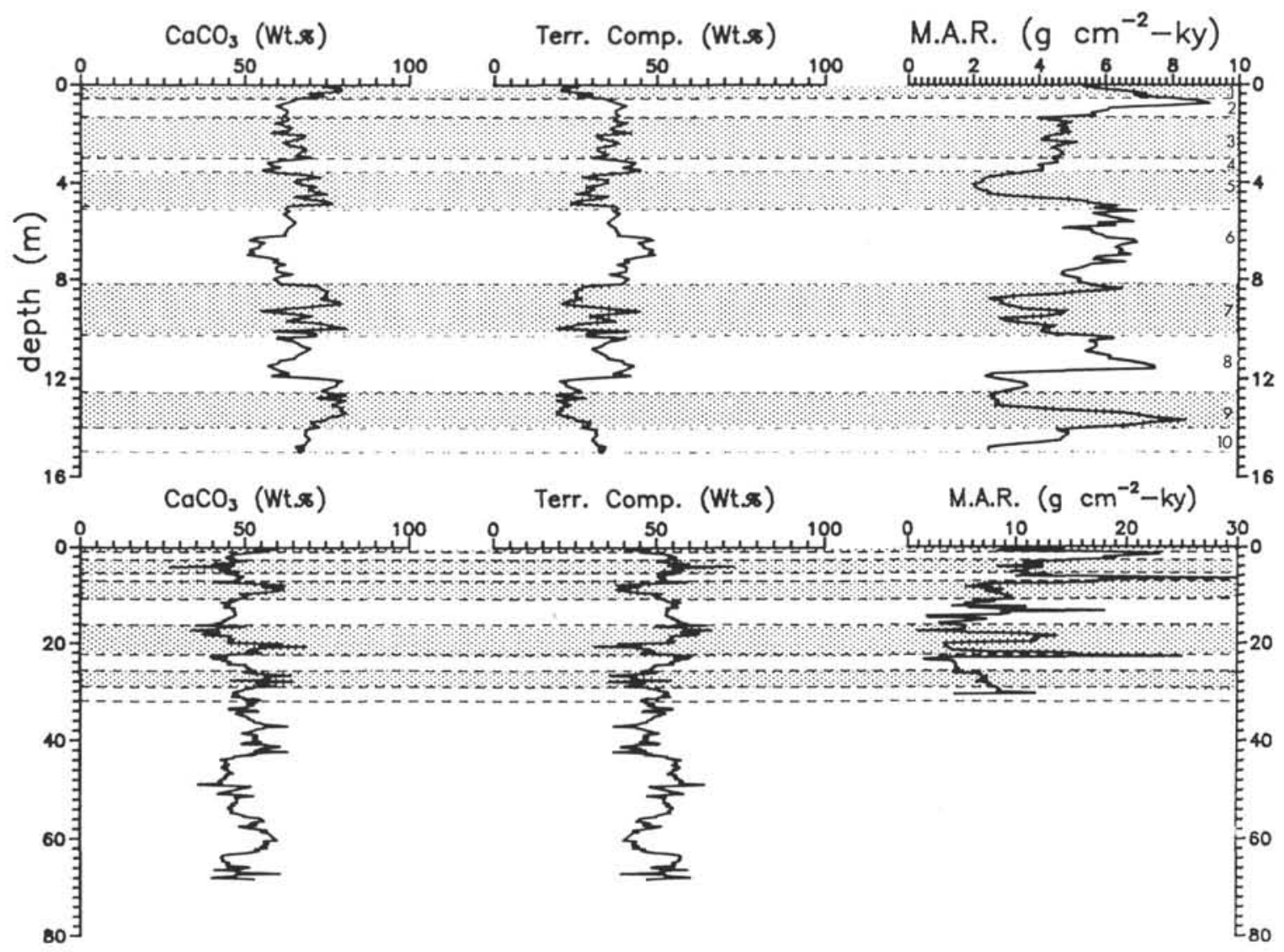

Figure 8. $\mathrm{CaCO}_{3}(\mathrm{wt} \%)$, terrigenous component $\left(100-\mathrm{CaCO}_{3} ; \mathrm{wt} \%\right)$, and mass accumulation rate $\left(\mathrm{g} \mathrm{cm}^{-2} \mathrm{k} . \mathrm{y} .{ }^{-1}\right)$ with depth for Holes 722B (top) and 724C (bottom).

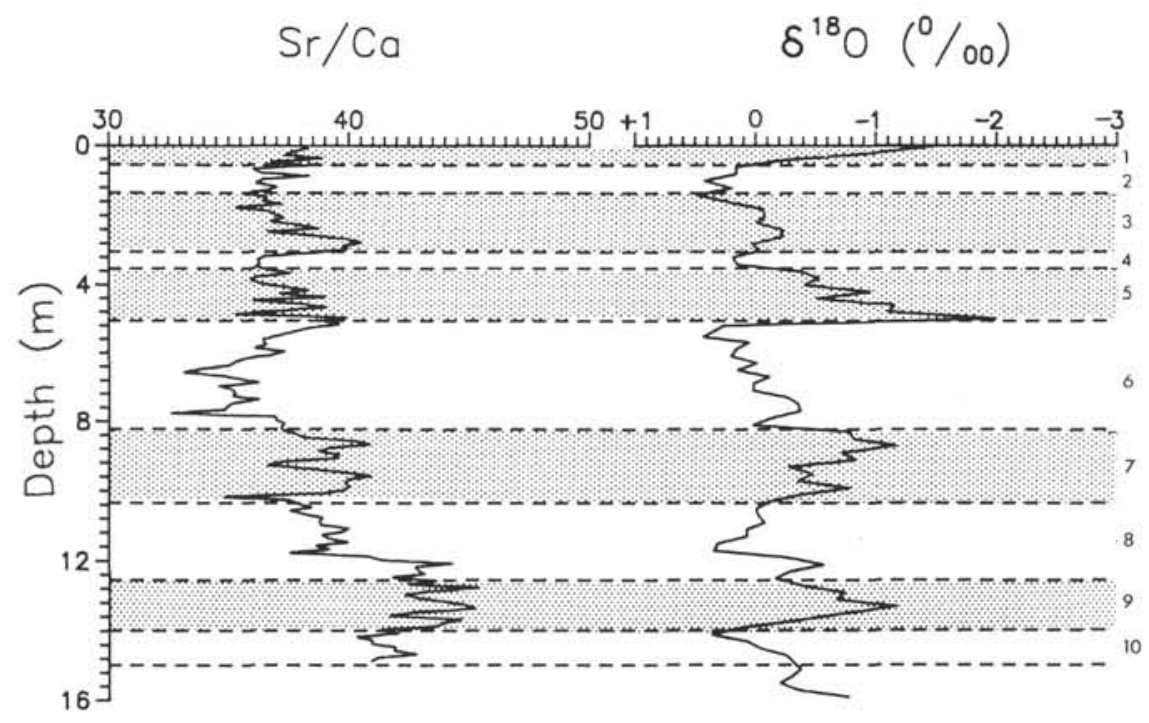

Figure 9. $\mathrm{Sr} / \mathrm{Ca}\left(\times 10^{-4}\right)$ weight ratio and $\delta^{18} \mathrm{O}$ with depth in Hole $722 \mathrm{~B}$.

The content and distribution of $\mathrm{Si}$ in these late Pleistocene sediments may be attributed to both detrital terrigenous clays and quartz, and to biogenic opal. Figure 10 displays the depth profiles at Sites 722 and 724 . It is immediately apparent that there are two important differences between the sites. At Site 722 the depth profile appears to have a constant $\mathrm{Si} / \mathrm{Al}$ ratio of 3.8 with occasional major increases (shale has a ratio of 3.4 ;
Turekian and Wedepohl, 1961). At Site 724, however, the overall $\mathrm{Si} / \mathrm{Al}$ is rather higher (about 5.0) but is variable without such a well defined baseline. However, both sites display high $\mathrm{Si} / \mathrm{Al}$ ratios in the Holocene section (Stage 1). Labracherie et al. (1983) studied the stratigraphic distribution of diatoms over the last 25 k.y. and has shown that opal productivity was (and is) higher in the Holocene. At Site 722, comparison of the $\mathrm{Si} / \mathrm{Al}$ record with 


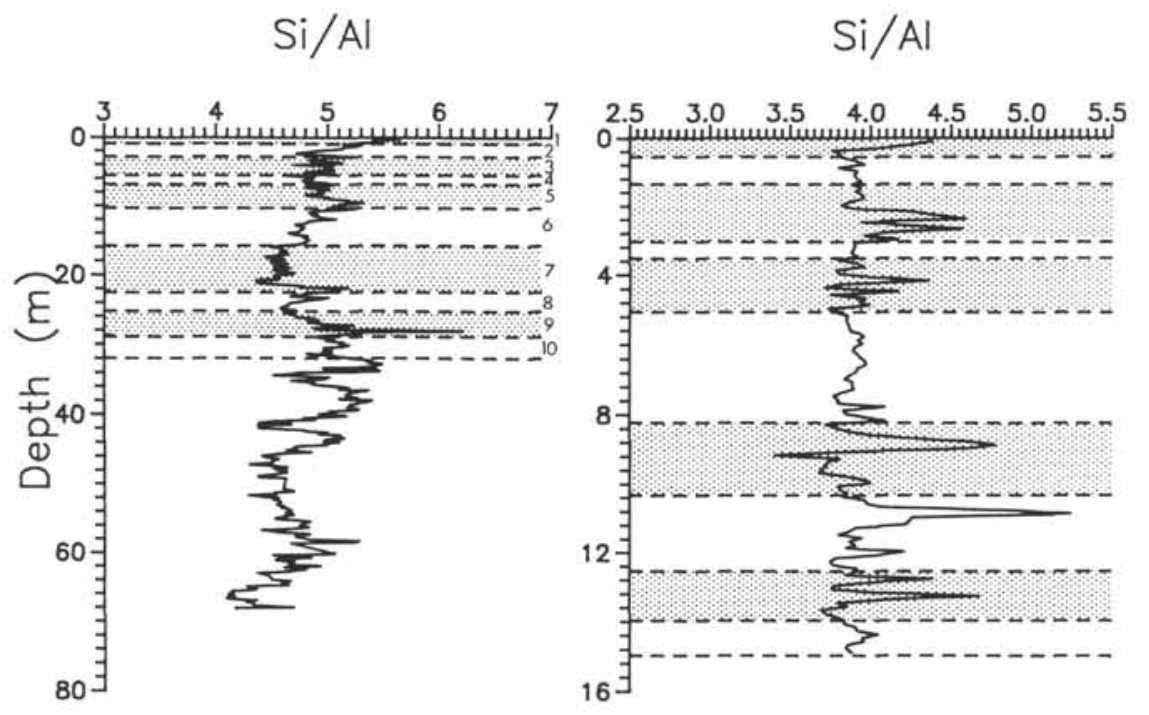

Figure 10. Si/Al (weight ratio) with depth in Holes 722B (left) and 724C (right).

unpublished opal data (determined by wet chemistry) from the site survey core (RC27-61; D. Murray, pers. comm., 1989) suggests that the spikes are indeed due to higher contents of biogenic opal. If this record reflects a constant clay and quartz input, with additions of biogenic opal, then the periodicity of the record (see Weedon and Shimmield, this volume) at $56 \mathrm{k.y}$. and $25 / 19$ k.y. reflects both precession and an unknown forcing component. The 56 k.y. periodicity has also been observed in $\mathrm{SiO}_{2}$ records from this leg (S. Clemens, pers. comm., 1989) but remains unexplained. At Site 724 the much higher $\mathrm{Si} / \mathrm{Al}$ ratio, and the core location on the continental slope, suggests that quartz may be rather more dominant. This is confirmed by smear slide analysis (Shipboard Scientific Party, 1989a, b) which indicates about $10 \%$ quartz in Unit I of Hole $724 \mathrm{C}$, and only trace amounts in Hole $722 \mathrm{~B}$. Interestingly, the $\mathrm{Si} / \mathrm{Al}$ profile in Site 724 is antithetically correlated with volume magnetic susceptibility (Shipboard Scientific Party, 1989a, b) suggesting that quartz dilutes the susceptibility record.

\section{Organic Matter (Productivity) Factor}

As we have seen above, both $\mathrm{CaCO}_{3}$ and $\mathrm{Si}$ are unreliable indicators of the paleoceanographic record of productivity variation in the Arabian Sea. However, one element, $\mathrm{Ba}$, is concentrated by marine organisms and may resist remineralization ("dissolution residue," Dymond, 1981) providing a tracer of paleoproductivity. Since the work of Revelle et al. (1955) many authors have commented on the association of $\mathrm{Ba}$, opal, and biogenic sedimentation. Despite the association of Ba-enriched sediments and regions of upwelling or enhanced productivity, no causal relationship has been definitely established (see review in Schmitz, 1987). Recent studies have suggested that Ba may be in heavy mineral granules functioning as statoliths (Fenchel and Finlay, 1984) within protozoans such as Xenophyophoria and Loxodes (Finlay et al., 1983). Very recently, Ba has been the subject of study in marine particles from the Gulf Stream (Bishop, 1988) and within the calcareous tests of benthic foraminifers (Lea and Boyle, 1989) and corals (Lea et al., 1989). Within the Indian Ocean the recent study of Schmitz (1987) has illustrated the use of $\mathrm{Ba}$ as a tracer of plate movement beneath the equatorial upwelling zone on a time scale of millions of years. To our knowledge there is no high-resolution record of $\mathrm{Ba}$ from an upwelling area influenced by climate change over a time scale of thousands of years.
Figure 11 illustrates the variation with depth of $\mathrm{Ba} / \mathrm{Al}$ at Site 722B on the Owen Ridge. The record is striking for two reasons: (1) the $\mathrm{Ba} / \mathrm{Al}$ has the largest dynamic range of any chemical variable measured here, and (2) the profile bears an almost perfect correlation with the $\delta^{18} \mathrm{O}$ stratigraphy. Clearly, elevated $\mathrm{Ba}$ contents are found during interglacial stages and must therefore reflect periods of enhanced productivity. (This conclusion holds even when considered in terms of flux, given the higher MAR of glacial periods. This is the advantage of having a tracer with so large a dynamic range.) In Figure 12 a periodogram of $\mathrm{Ba} / \mathrm{Al}$ displays the strong $100 \mathrm{k} . \mathrm{y}$. cycle that is apparent in the depth profile. As well as eccentricity cycle, both tilt ( $42 \mathrm{k} . \mathrm{y}$.) and precession (23/16 k.y.) are in evidence, again confirming the similarity of the $\mathrm{Ba}$ profile to the $\delta^{18} \mathrm{O}$ record. The phasing of this record is discussed further in Weedon and Shimmield (this volume).

From wind strength indicators (e.g., $\mathrm{Ti} / \mathrm{Al})$ we believe that the monsoon responds to forcing in the precession band. As upwelling is linked through Ekman transport to wind stress, it is expected that $\mathrm{Ba}$, as a productivity indicator, should also display similar precessional forcing. The fact that longer cycle ("global") forcing is also very evident suggests that nutrient supply to the northwest Arabian Sea may be important. In this context, recent models on deep and intermediate water ventilation or stagnation are pertinent (Keir, 1988; Duplessy et al., 1988) as shown by Cd/Ca tracers in benthic foraminifers (Boyle, 1986). Recent work by Boyle (1988) and Boyle and Keigwin (1987) has shown that intermediate waters in the North Atlantic became nutrient depleted together with reduced North Atlantic Deep Water Flux during the last glacial episode. As the predominant source of nutrients in this area is through upwelling of intermediate waters, changes in the nutrient profile of open ocean waters during glacial time may account for the weaker glacial productivity identified from the $\mathrm{Ba} / \mathrm{Al}$ signal. Further paleoceanographic studies should concentrate on establishing the nutrient levels of Indian ocean intermediate waters.

In addition to $\mathrm{Ba}$ as a direct indicator of changing productivity, the associated organic matter detritus will also affect the sediment geochemistry, either through direct metal complexing or through redox chemistry. Recently, studies by Thomson et al. (1987) have shown the importance of progressive redox fronts in preserving minor metal profiles in non-steady state conditions. Finney et al. (1988) have argued for productivity-induced redox 


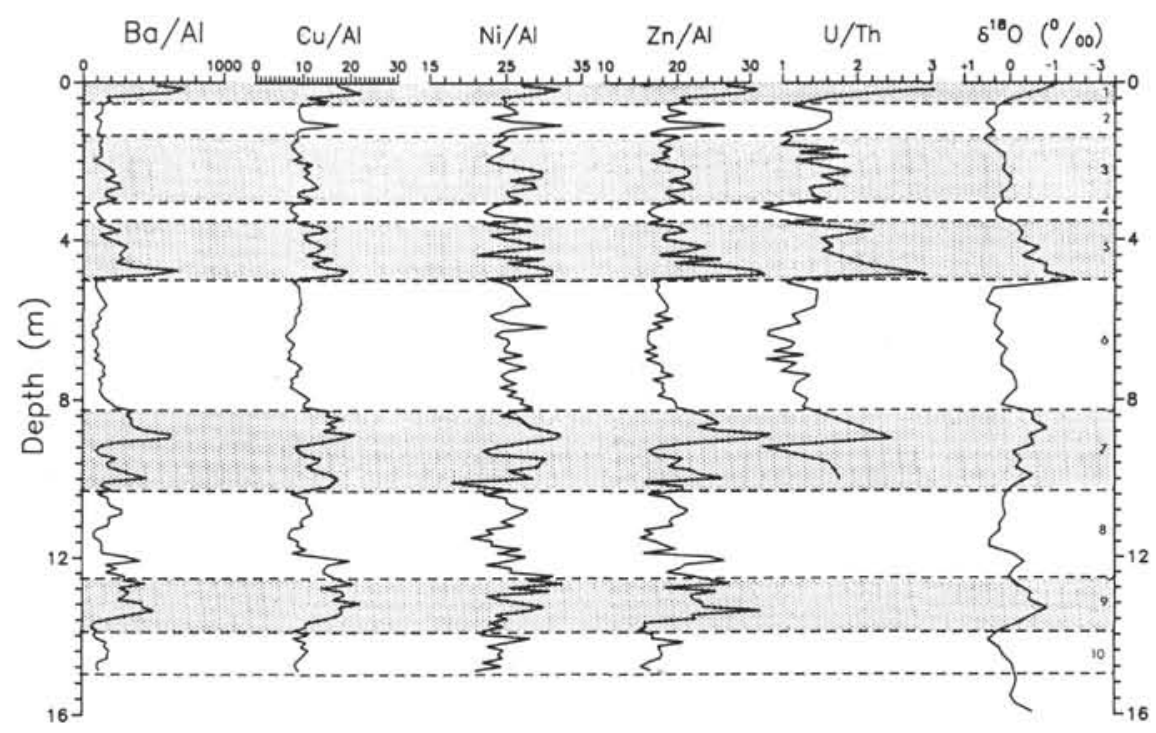

Figure 11. Element-to-Al weight ratios comprising the productivity factor with depth in Hole $722 \mathrm{~B}$, together with the $\delta^{18} \mathrm{O}$ stratigraphy. All ratios are $\times 10^{-4}$ except $\mathrm{U} / \mathrm{Th}$.

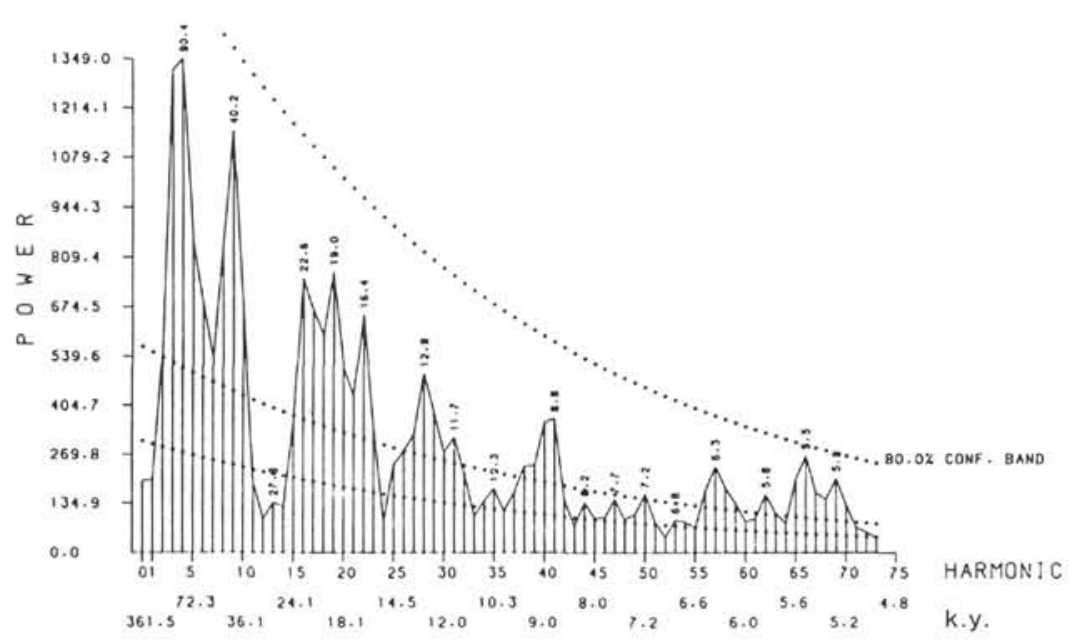

Figure 12. Ba/Al periodogram for Hole 722B.

variations in controlling transition metal distributions in sediments from the eastern equatorial Pacific. In Figure 11, $U$ and $\mathrm{Cu}$ are both enriched relative to aluminosilicate levels at depths corresponding to higher productivity periods (defined by $\mathrm{Ba}$ / $\mathrm{Al}$ ). As these two metals (and $\mathrm{V}$ ) are often associated with more reducing conditions brought about by higher organic matter fluxes (or expansion of the OMZ to intersect the ridge crest) this observation is consistent. The weaker association of $\mathrm{Ni} / \mathrm{Al}$ and $\mathrm{Zn} / \mathrm{Al}$ is possibly incurred as particulate organic matter is known to be an effective scavenger of transition metals. The importance of subsurface redox fronts and accumulation rate fluxes is discussed further in Shimmield and Mowbray (this volume). Sediment trap studies in the Sargasso Sea (Jickells et al., 1984) have demonstrated the very close association of $\mathrm{Cu}, \mathrm{Ni}, \mathrm{V}$, and $\mathrm{Zn}$ (also $\mathrm{Fe}, \mathrm{Mn}, \mathrm{P}$, and $\mathrm{Pb}$ ) fluxes with total organic carbon flux. They attribute the close association to seasonality driven by changes in primary productivity in the overlying surface waters. Particulate forms of the elements are rapidly consolidated and sedimented with the organic matter.

\section{Phosphatic Factor}

The occurrence of phosphatic material accumulating in sediments underlying upwelling zones has been long recognized (Burnett, 1977; and others). This material may be diagenetic in origin, or of biogenic skeletal (fish teeth and bones) nature. Both phases are known to concentrate the rare earth elements. In Figure 3 the clear association of $\mathrm{P}$ with $\mathrm{Ce}, \mathrm{Y}$, and $\mathrm{Nd}$ may be seen. Similar statistical analysis by $\mathrm{Li}(1982)$ also recognized the existence of phosphate minerals and REE's in sediments. At Site 722 the phosphatic sediments (identified by the P/Al ratio) are more common during interglacial stages (Fig. 13) with an average $\mathrm{P} / \mathrm{Al}$ ratio of 0.025 in the upper $16 \mathrm{~m}$. We may attribute this distribution to the effect of elevated interglacial productivity, as identified by the tracers described above. However, at Site 724 a rather different distribution is recorded (Fig. 13). Here the baseline $\mathrm{P} / \mathrm{Al}$ ratio is roughly the same $(0.02-0.03)$ but highly enriched phosphate horizons (reaching a maximum $\mathrm{P} / \mathrm{Al}$ of $\sim 0.4$ ) are recorded. These enriched horizons also occur within 

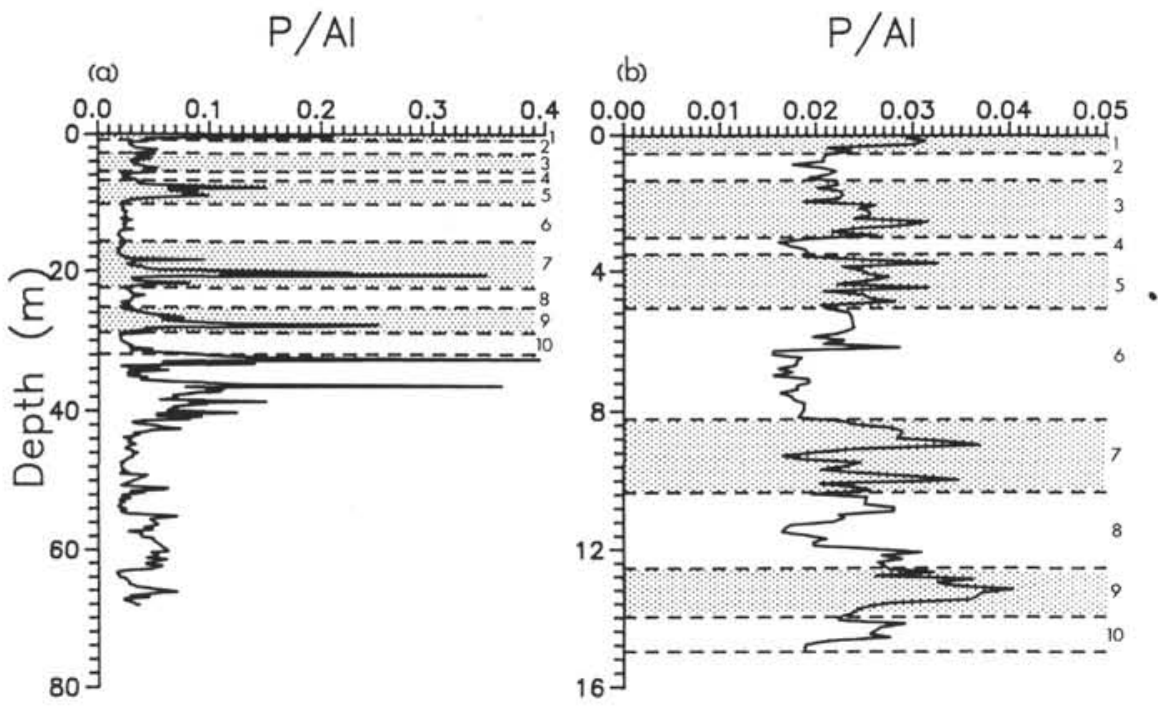

Figure 13. P/Al weight ratio with depth for Holes 722B (left) and 724C (right).

interglacial sediments suggesting their origin is also linked to high productivity episodes. The phase containing the phosphate is unknown, but phosphate nodules at a depth of about $44 \mathrm{~m}$ were recorded by the Shipboard Scientific Party (1989b) in Hole 724A.

\section{CONCLUSION}

The results presented here together with their interpretation suggest that the Oman margin has experienced major changes in productivity and upwelling history during the late Pleistocene. Through the use of high-resolution inorganic geochemistry, together with a unique sedimentary record provided by hydraulic piston coring, we have been able to define the pattern of these climate changes.

The Southwest Monsoon (and associated northwest windsthe Shamal; Sirocko and Sarnthein, 1989) appears to be responsible for the bulk of the eolian dust input to the northwest Arabian Sea. This dust input may be clearly identified by the Ti/Al and $\mathrm{Cr} / \mathrm{Al}$ record, and occurs with a frequency that suggests forcing by orbital precession. This result is in agreement with other proxy-indicators that have been shown to display similar forcing (Prell and Kutzbach, 1987).

The record of biogenic productivity is more involved, responding to both local upwelling intensity and changes in the global ocean/climate system. The record of bulk biogenic carbonate is strongly influenced by, and inversely correlated with, terrigenous aluminosilicate detritus. Some biogenic silica occurs at Site 722. Using time series analysis, the opal distribution curves reflect both precession and an unknown forcing component at $56 \mathrm{k} . \mathrm{y}$. The dominant contribution to the total $\mathrm{Si}$ measured in these sediments is from clay and quartz. The question of why an upwelling area that at the present day supports high opal productivity (diatoms), but fails to record changes in this opal productivity within the sediments, requires further study.

In this study $\mathrm{Ba}$ has proved to be an excellent indicator of changes in productivity with time. The record closely follows the $\delta^{18} \mathrm{O}$ signal recorded in planktonic foraminifers, suggesting that not only local upwelling, but ocean-wide changes in nutrient supply, may influence the biological community. Responding to these changes in productivity is the flux of biological detritus (fecal material, tissue, skeletons) to the sediments, which drive redox variations in the sediment, and/or changes in the intensity and depth of the oxygen minimum zone. This is recorded in the geochemistry of $\mathrm{Cu}, \mathrm{Ni}, \mathrm{Zn}, \mathrm{V}$, and $\mathrm{U}$, all of which identify interglacial episodes as being more productive.
The detritus of biogenic material promotes active phosphogenesis within the sediments. Both diagenetic enrichment of phosphate and the accumulation of phosphatic skeletal hard parts occurs within the sediments of the Oman Margin and Owen Ridge. Their distribution also reflects the higher productivity of interglacial episodes. This observation that temporal trends in productivity in the northwest Arabian Sea are out of phase with those in the Panama Basin and off northwest Africa, where higher productivity occurs during glacial episodes, will require an answer from integrated studies of ocean productivity and upwelling through time.

\section{ACKNOWLEDGMENTS}

We wish to thank staff and crew of the Ocean Drilling Program and the JOIDES Resolution for the opportunity to undertake this study. We especially grateful to Warren Prell, Kay Emeis, Brian Price, Tom Pedersen, Dave Murray, and Steve Clemens for helpful discussions on this project. Drs. R. François and H.J. Brumsack provided critical and stimulating reviews. GBS acknowledges the support of NERC Grant GST/02/315 from the ODP Special Topic fund.

\section{REFERENCES}

Adelseck, C. G., Jr., and Anderson, T. F., 1978. The late Pleistocene record of productivity fluctuations in the eastern equatorial Pacific Ocean. Geology, 6:388-391.

Baker, P. A., Gieskes, J. M., and Elderfield, H., 1982. Diagenesis of carbonates in deep-sea sediments: evidence from $\mathrm{Sr}^{2+} / \mathrm{Ca}^{2+}$ ratios and interstitial dissolved $\mathrm{Sr}^{2+}$ data. J. Sediment. Petrol., 52:71-82.

Bishop, J.K.B., 1988. The barite-opal organic carbon association in oceanic particulate matter. Nature, 332:341-343.

Bonatti, E., Fisher, D. E., Joensuu, O., and Rydell, H. S., 1971. Postdepositional mobility of some transition elements, phosphorus, uranium and thorium in deep-sea sediments. Geochim. Cosmochim. Acta, 35:189-201.

Bonatti, E., Simmons, E. C., Berger, D., Hamlyn, P. R., and Lawrence, L., 1983. Ultramafic rock/seawater interaction in the oceanic crust. Mg-silicate (sepiolite) deposit from the Indian Ocean floor. Earth Planet. Sci. Lett., 62:229-238.

Boyle, E. A., 1983. Chemical accumulation variations under the Peru Current during the past 130,000 years. J. Geophys. Res., 88:76677680.

1986. Paired carbon isotope and cadmium data from benthic foraminifera: implications for changes in oceanic phosphorus, oceanic circulation, and atmospheric carbon dioxide. Geochim. Cosmochim. Acta, 50:265-276. 
1988. The role of vertical chemical fractionation in controlling late Quaternary atmospheric carbon dioxide. J. Geophys. Res., 93:15701-15714.

Boyle, E. A., and Keigwin, L., 1987. North Atlantic thermohaline circulation during the past 20,000 years linked to high-latitude surface temperature. Nature, 330:35-40.

Church, T. M., 1979. Marine barite. In Burns, R. G. (Ed.), Reviews in Mineralogy (Vol. 6). Mineral Soc. Am., 175-209.

CLIMAP Project Members, 1976. The surface of the ice-age Earth. Science, 191:1131-1137.

Duplessy J. C., Shackleton, N. J., Fairbanks, R. G., Labeyrie, L., Oppo, D., and Kallel, N., 1988. Deepwater source variations during the last climatic cycle and their impact on global deepwater circulation. Paleoceanography, 3:343-360.

Dymond, J., 1981. Geochemistry of Nazca plate surface sediments: An evaluation of hydrothermal, biogenic, detrital, and hydrogenous sources. Mem. Geol. Soc. Am., 154:133-173.

Fenchel, T., and Finlay, B. J., 1984. Geotaxis in the ciliated protozoan, Loxodes. J. Exp. Biol., 110:17-33.

Finlay, B. J., Hetherington, N. B., and Davison, W., 1983. Active biological participation in lacustrine barium geochemistry. Geochim. Cosmochim. Acta, 47:1325-1329.

Finney, B. P., Lyle, M. W., and Heath, G. R., 1988. Sedimentation at MANOP Site H (eastern equatorial Pacific) over the past 400,000 years: climatically induced redox variations and their effects on transition metal cycling. Paleoceanography, 3:169-189.

Imbrie, J., Hays, J. D., Martinson, D. G., McIntyre, A., Mix, A. C. Morley, J. J., Pisias, N. G., Prell, W. L., and Shackleton, N. J., 1984. The orbital theory of Pleistocene climate: support from a revised chronology of the marine delta $\delta^{18} \mathrm{O}$ record. In Berger, A., Imbrie, J., Hays, J., Kukla, G., and Saltzman, B. (Eds.), Milankovitch and Climate (Pt. 1): Dordrecht (D. Reidel), 269-305.

Jickells, T. D., Deuser, W. G., and Knap, A. H., 1984. The sedimentation rates of trace elements in the Sargasso Sea measured by sediment trao. Deep-Sea Res. Part A, 31:1169-1178.

Keir, R. S., 1988. On the late Pleistocene ocean geochemistry and circulation. Paleoceanography, 3:413-445.

Kolla, V., Ray, P. K., and Kostecki, J. A., 1981. Surficial sediments of the Arabian Sea. Mar. Geol., 41:183-204.

Labracherie, M., Barde, M.-F., Moyes, J., and Pujos-Lamy, A., 1983. Variability of upwelling regimes (northwest Africa, south Arabia) during the latest Pleistocene: a comparison. In Suess, E., and Thiede, J. (Eds.), Coastal Upwelling, Its Sediment Record: New York (Plenum), 347-364.

Lea, D., and Boyle, E. A., 1989. Barium content of benthic foraminifera controlled by bottom-water composition. Nature, 338:751-753.

Lea, D. W., Shen, G. T., and Boyle, E. A., 1989. Coralline barium records temporal variability in equatorial Pacific upwelling. Nature, 340:373-376.

Li, Y.-H., 1982. Interelement relationship in abyssal Pacific ferromanganese nodules and associated pelagic sediments. Geochim. Cosmochim. Acta, 46:1053-1060.

Lyle, M., Heath, G. R., Murray, D. W., Finney, B. P., Dymond, J., Robbins, J. M., and Brooksforce, K., 1988. The record of late Pleistocene sedimentation in the eastern equatorial Pacific Ocean. Paleoceanography, 3:39-59.

McMurtry, G. M., and Yeh, H. W., 1981. Hydrothermal clay mineral formation of East Pacific Rise and Bauer Basin sediments. Chem. Geol., 32:189-205.

Moseley, F., and Abbotts, I. L., 1979. The Ophiolite mélange of Masirah, Oman. J. Geol. Soc. London, 136:713-724.

Nath, B. G., Rao, V. P., and Becker, K. P., 1989. Geochemical evidence of terrigenous influence in deep-sea sediments up to $8^{\circ} \mathrm{S}$ in the central Indian basin. Mar. Geol., 87:301-313.

Norrish, K., and Hutton, J. T., 1969. An accurate X-ray spectrographic method for the analysis of a wide range of geological samples. Geochim. Cosmochim. Acta, 33:431-453.

Pedersen, T. F., 1983. Increased productivity in the eastern equatorial Pacific during the last glacial maximum (19,000 to 14,000 yr B.P.). Geology, 11:16-19.

Pedersen, T. F., Pickering, M., Vogel J. S., Southon, J. N., and Nelson, D. E., 1988. The response of benthic foraminifera to productivity cycles in the eastern equatorial Pacific: faunal and geochemical constraints on glacial bottom water oxygen levels. Paleoceanography, 3: 157-168.
Prell, W. L., 1984a. Monsoonal climate of the Arabian Sea during the late Quaternary: a response to changing solar radiation. In Berger, A. L., Imbrie, J., Hays, J., Kukla, G., and Saltzman, B. (Eds.). Milankovitch and Climate (Pt. 1): Dordrecht (D. Reidel), 349-366.

1984B. Variation of monsoonal upwelling: a response to changing solar radiation. In Hansen, J. E., and Takahashi, T. (Eds.), Climatic Processes and Climate Sensitivity. Am. Geophys. Union, Maurice Ewing Ser., 5:48-57.

Prell, W. L., and Kutzbach, J. E., 1987. Monsoon variability over the past 150,000 years. J. Geophys. Res., 92:8411-8425.

Prell, W. L., and Van Campo, E., 1986. Coherent response of Arabian Sea upwelling and pollen transport to late Quaternary monsoonal winds. Nature, 323:526-528.

Quasim, S. Z., 1982. Oceanography of the northern Arabian Sea. DeepSea Res. Part A, 29:1041-1068.

Rao, D. P., and Jayaramna, R., 1970. On the occurrence of oxygen maxima and minima in the upper 500 meters of the north-west Indian Ocean. Proc. Indian Acad. Sci., 71B:230-246.

Revelle, R., Bramlette, M., Arrhenius, G., and Goldberg, E. D., 1955. Pelagic sediments of the Pacific. Spec. Pap.-Geol. Soc. Am., 62: 221-235.

Schmitz, B., 1987. The $\mathrm{TiO}_{2} / \mathrm{Al}_{2} \mathrm{O}_{3}$ ratio in the Cenozoic Bengal Abyssal Fan sediments and its use as a paleostream energy indicator. Mar. Geol., 76:195-206.

Sen Gupta, R., Fondekar, S. P., Sankaranarayanan, V. E., and De Sousa, S. N., 1975. Chemical oceanography of the Arabian Sea. Part 1. Hydrochemical and hydrographical features of the northern basin. Indian J. Mar. Sci., 4:136-140.

Shankar, R., Subbarao, K. V., and Kolla, V., 1987. Geochemistry of surface sediments from the Arabian Sea. Mar. Geol., 76:253-279.

Shimmield, G. B., 1985. The geochemistry and mineralogy of Pacific sediments, Baja California, Mexico [Ph.D. dissert.]. Univ. of Edinburgh, Edinburgh.

Shimmield, G. B., Price, N. B., and Pedersen, T. F., 1990. The influence of hydrography, bathymetry, and productivity on sediment type and composition from the Oman margin and the northwest Arabian Sea. In Robertson, A.H.F., Searle, M. P., and Ries, A. C. (Eds.), The Geology and Tectonics of the Oman Region. Spec. Publ. Geol. Soc., 49:761-771.

Shipboard Scientific Party, 1989a. Site 722. In Prell, W. L., Niitsuma, N., et al., Proc. ODP, Init. Repts., 117: College Station, TX (Ocean Drilling Program), 255-318.

1989b. Site 724. In Prell, W. L., Niitsuma, N., et al., Proc. ODP, Init. Repts., 117: College Station, TX (Ocean Drilling Program), 385-418.

Sirocko, F., and Sarnthein, M., 1989. Wind-borne deposits in the northwest Indian Ocean: record of Holocene sediments versus modern satellite data. In Leinen, M., and Sarnthein, M. (Eds.), Paleoclimatology and Paleometeorology: Modern and Past Patterns of Global Atmospheric Transport. NATO ASI Ser., 401-433.

Slater, R. D., and Kroopnick, P., 1984. Controls on dissolved oxygen distribution and organic carbon deposition in the Arabian Sea. In Haq, B. U., and Milliman, J. D. (Eds.), Marine Geology and Oceanography of Arabian Sea and Coastal Pakistan. New York (Van Nostrand Reinhold), 305-313.

Spears, D. A., and Kanaris-Sotiriou, R., 1976. Titanium in some Carboniferous sediments from Great Britain. Geochim. Cosmochim. Acta, 40:345-351.

Thomson, J., Colley, S., Higgs, N., Hydes, D. J., Wilson, T.R.S., and S $\phi$ rensen, J., 1987. Geochemical oxidation fronts in NE Atlantic distal turbidites and their effects on the sedimentary record. In Weaver, P.P.E., and Thomson, J. (Eds.), Geology and Geochemistry of Abyssal Plains, Spec. Publ. Geol. Soc., 31:167-178.

Turekian, K. K., and Wedepohl, K. H., 1961. Distribution of the elements in some major units of the earth's crust. Geol. Soc. Am. Bull., 72:175-192.

Van Campo, E., Duplessy, J. C., and Rossignol-Strict, M., 1982. Climatic conditions deduced from a 150-kyr oxygen isotope-pollen record from the Arabian Sea. Nature, 296:56-59.

Date of initial receipt: 28 September 1989

Date of acceptance: 20 July 1990

Ms 117B-170 
APPENDIX A

Hole 722B Cores $1 \mathrm{H}$ and $2 \mathrm{H}$ Corrected for Salt Contribution and Dilution.

\begin{tabular}{|c|c|c|c|c|c|c|c|c|c|c|}
\hline $\begin{array}{c}\text { Sample } \\
\text { identification }\end{array}$ & $\begin{array}{l}\text { Depth } \\
\text { (mbsf) }\end{array}$ & $\begin{array}{l}\text { Density } \\
\left(\mathrm{g} / \mathrm{cm}^{3}\right)\end{array}$ & $\begin{array}{l}{ }^{a} \text { Age } \\
\text { (k.y.) }\end{array}$ & $\begin{array}{c}\mathrm{Si} \\
(w t \%)\end{array}$ & $\underset{(w t \%)}{\mathrm{Al}}$ & $\begin{array}{c}\mathrm{Fe} \\
(w t \%)\end{array}$ & $\underset{(w t \%)}{\mathrm{Ca}}$ & $\underset{(w t \%)}{\mathrm{Ti}}$ & $\underset{(w t \%)}{M n}$ & $\underset{\text { (wt } \%)}{P}$ \\
\hline 722B-1H-01, 06-08 cm & 0.07 & 0.77 & 6.0 & 6.176 & 1.409 & 0.890 & 30.311 & 0.095 & 0.018 & 0.041 \\
\hline $722 \mathrm{~B}-1 \mathrm{H}-01,16-18 \mathrm{~cm}$ & 0.17 & 0.79 & 7.5 & 4.748 & 1.111 & 0.723 & 32.318 & 0.073 & 0.019 & 0.035 \\
\hline $722 \mathrm{~B}-1 \mathrm{H}-01,26-28 \mathrm{~cm}$ & 0.27 & 0.87 & 9.0 & 4.555 & 1.111 & 0.732 & 32.283 & 0.071 & 0.018 & 0.034 \\
\hline $722 \mathrm{~B}-1 \mathrm{H}-01,36-38 \mathrm{~cm}$ & 0.37 & 0.91 & 10.2 & 7.418 & 1.973 & 1.240 & 28.648 & 0.135 & 0.025 & 0.042 \\
\hline $722 \mathrm{~B}-1 \mathrm{H}-01,46-48 \mathrm{~cm}$ & 0.47 & 0.87 & 11.5 & 6.009 & 1.578 & 1.006 & 30.306 & 0.109 & 0.019 & 0.037 \\
\hline $722 \mathrm{~B}-1 \mathrm{H}-01,56-58 \mathrm{~cm}$ & 0.57 & 0.93 & 12.8 & 8.077 & 2.115 & 1.312 & 27.246 & 0.147 & 0.027 & 0.045 \\
\hline $722 \mathrm{~B}-1 \mathrm{H}-01,66-68 \mathrm{~cm}$ & 0.67 & 0.97 & 14.0 & 8.673 & 2.219 & 1.322 & 26.661 & 0.153 & 0.024 & 0.046 \\
\hline $722 \mathrm{~B}-1 \mathrm{H}-01,76-78 \mathrm{~cm}$ & 0.77 & 0.97 & 15.0 & 9.260 & 2.340 & 1.426 & 25.705 & 0.168 & 0.029 & 0.049 \\
\hline $722 \mathrm{~B}-1 \mathrm{H}-01,86-88 \mathrm{~cm}$ & 0.87 & 1.00 & 16.1 & 10.223 & 2.687 & 1.636 & 24.741 & 0.187 & 0.034 & 0.047 \\
\hline $722 \mathrm{~B}-1 \mathrm{H}-01,96-98 \mathrm{~cm}$ & 0.97 & 0.96 & 17.2 & 9.373 & 2.389 & 1.464 & 25.454 & 0.172 & 0.028 & 0.049 \\
\hline $722 \mathrm{~B}-1 \mathrm{H}-01,106-108 \mathrm{~cm}$ & 1.07 & 0.95 & 19.2 & 9.145 & 2.344 & 1.507 & 26.074 & 0.166 & 0.025 & 0.052 \\
\hline $722 \mathrm{~B}-1 \mathrm{H}-01,116-118 \mathrm{~cm}$ & 1.17 & 0.97 & 21.2 & 9.035 & 2.312 & 1.448 & 26.053 & 0.166 & 0.026 & 0.049 \\
\hline $722 \mathrm{~B}-1 \mathrm{H}-01,126-128 \mathrm{~cm}$ & 1.27 & 1.02 & 22.3 & 9.646 & 2.447 & 1.554 & 25.561 & 0.172 & 0.028 & 0.047 \\
\hline $722 \mathrm{~B}-1 \mathrm{H}-01,136-138 \mathrm{~cm}$ & 1.37 & 0.95 & 25.5 & 9.038 & 2.327 & 1.437 & 26.202 & 0.166 & 0.029 & 0.051 \\
\hline $722 \mathrm{~B}-1 \mathrm{H}-01,146-148 \mathrm{~cm}$ & 1.47 & 0.97 & 27.7 & 9.197 & 2.335 & 1.465 & 26.123 & 0.168 & 0.026 & 0.052 \\
\hline 722B-1H-02, 06-08 cm & 1.57 & 1.04 & 29.8 & 10.188 & 2.603 & 1.592 & 24.611 & 0.185 & 0.026 & 0.052 \\
\hline $722 \mathrm{~B}-1 \mathrm{H}-02,16-18 \mathrm{~cm}$ & 1.67 & 0.94 & 31.9 & 9.358 & 2.371 & 1.489 & 25.634 & 0.172 & & 0.054 \\
\hline $722 \mathrm{~B}-1 \mathrm{H}-02,26-28 \mathrm{~cm}$ & 1.77 & 1.01 & 34.0 & 9.008 & 2.273 & 1.407 & 26.590 & 0.164 & 0.027 & 0.052 \\
\hline $722 \mathrm{~B}-1 \mathrm{H}-02,36-38 \mathrm{~cm}$ & 1.87 & 0.94 & 36.0 & 9.166 & 2.365 & 1.445 & 26.229 & 0.167 & 0.025 & 0.053 \\
\hline $722 \mathrm{~B}-1 \mathrm{H}-02,46-48 \mathrm{~cm}$ & 1.97 & 1.00 & 38.1 & 9.952 & 2.606 & 1.474 & 24.132 & 84 & 0.031 & 0.049 \\
\hline 722B-1H-02, 56-58 cm & 2.07 & 0.88 & 40.1 & 7.691 & 1.983 & 1.201 & 28.251 & 0.145 & 0. & 0.052 \\
\hline $722 \mathrm{~B}-1 \mathrm{H}-02,66-68 \mathrm{~cm}$ & 2.17 & 0.84 & 42.1 & 8.039 & 1.883 & 1.191 & 27.894 & 0.141 & 0.024 & 0.046 \\
\hline $722 \mathrm{~B}-1 \mathrm{H}-02,76-78 \mathrm{~cm}$ & 2.27 & 0.83 & 44.1 & 8.963 & 2.036 & 1.265 & 26.595 & 0.153 & 0.025 & 0.052 \\
\hline $722 \mathrm{~B}-1 \mathrm{H}-02,86-88 \mathrm{~cm}$ & 2.37 & 1.07 & 46.2 & 9.246 & 2.014 & 1.401 & 25.506 & 0.145 & 0.022 & 0.052 \\
\hline 722B-1H-02, 96-98 cm & 2.47 & 0.94 & 48.2 & 8.862 & 2.251 & 1.368 & 26.271 & 0.163 & 0.025 & 0.054 \\
\hline $722 \mathrm{~B}-1 \mathrm{H}-02,106-108 \mathrm{~cm}$ & 2.57 & 0.89 & 50.3 & 7.690 & 1.828 & 1.180 & 28.143 & 0.133 & 0.021 & 0.058 \\
\hline $722 \mathrm{~B}-1 \mathrm{H}-02,116-118 \mathrm{~cm}$ & 2.67 & 0.92 & 52.3 & 8.019 & 1.756 & 1.137 & 28.115 & 0.127 & 0.021 & 0.052 \\
\hline $722 \mathrm{~B}-1 \mathrm{H}-02,126-128 \mathrm{~cm}$ & 2.77 & 0.96 & 54.3 & 7.820 & 1.911 & 1.183 & 27.309 & 0.134 & 0.025 & 0.045 \\
\hline $722 \mathrm{~B}-1 \mathrm{H}-02,136-138 \mathrm{~cm}$ & 2.87 & 0.94 & 56.3 & 7.496 & 1.892 & 1.178 & 26.861 & 0.131 & 0.020 & 0.041 \\
\hline $722 \mathrm{~B}-1 \mathrm{H}-02,146-148 \mathrm{~cm}$ & 2.97 & 0.90 & 58.4 & 7.207 & 1.7 & 1.116 & 28.918 & 0.124 & 0.023 & 0.046 \\
\hline 722B-1H-03, 06-08 cm & 3.07 & 1.00 & 60.4 & 9.369 & 2.401 & 1.460 & 26.046 & 0.171 & 6 & 0.046 \\
\hline $722 \mathrm{~B}-1 \mathrm{H}-03,16-18 \mathrm{~cm}$ & 3.17 & 1.10 & 62.5 & 12.217 & 3.134 & 1.896 & 23.770 & 0.222 & 0.0 & 0.050 \\
\hline $722 \mathrm{~B}-1 \mathrm{H}-03,26-28 \mathrm{~cm}$ & 3.27 & 1.00 & 65.1 & 11.010 & 2.834 & 1.674 & 24.167 & 0.204 & 0.030 & 0.049 \\
\hline $722 \mathrm{~B}-1 \mathrm{H}-03,36-38 \mathrm{~cm}$ & 3.37 & 1.10 & 67.7 & 10.109 & 2.607 & 1.574 & 25.258 & 0.188 & 0.029 & 0.049 \\
\hline $722 \mathrm{~B}-1 \mathrm{H}-03,46-48 \mathrm{~cm}$ & 3.47 & 1.14 & 70.1 & 10.728 & 2.736 & 1.672 & 23.040 & 0.203 & 0.028 & 0.052 \\
\hline $722 \mathrm{~B}-1 \mathrm{H}-03,56-58 \mathrm{~cm}$ & 3.57 & 1.08 & 73.2 & 10.178 & 2.678 & 1.606 & 24.667 & 0.181 & 0.025 & 0.050 \\
\hline $722 \mathrm{~B}-1 \mathrm{H}-03,66-68 \mathrm{~cm}$ & 3.67 & 1.03 & 76.2 & 7.867 & 2.009 & 1.230 & 28.328 & 0.144 & 0.026 & 0.050 \\
\hline $722 \mathrm{~B}-1 \mathrm{H}-03,76-78 \mathrm{~cm}$ & 3.77 & 0.99 & 79.2 & 6.604 & 1.670 & 1.097 & 29.959 & 0.118 & 0.022 & 0.054 \\
\hline $722 \mathrm{~B}-1 \mathrm{H}-03,86-88 \mathrm{~cm}$ & 3.87 & 1.07 & 84.1 & 8.720 & 2.308 & 1.514 & 27.048 & 0.161 & 0.026 & 0.052 \\
\hline $722 \mathrm{~B}-1 \mathrm{H}-03,96-98 \mathrm{~cm}$ & 3.97 & 1.05 & 89.0 & 7.838 & 2.0 & 1.283 & 26. & 0.140 & 1 & 0.051 \\
\hline 722B-1H-03, 106-108 cm & 4.07 & 0.95 & 93.5 & 7.680 & 1.913 & 3.130 & 27. & 0.146 & 0. & 0.048 \\
\hline $722 \mathrm{~B}-1 \mathrm{H}-03,116-118 \mathrm{~cm}$ & 4.17 & 0.93 & 98.0 & 6.974 & 1.600 & 1.044 & 29.472 & 0.117 & 0.024 & 0.044 \\
\hline $722 \mathrm{~B}-1 \mathrm{H}-03,126-128 \mathrm{~cm}$ & 4.27 & 1.07 & 103.2 & 7.667 & 2.019 & 1.231 & 28.841 & 0.139 & 0.022 & 0.051 \\
\hline $722 \mathrm{~B}-1 \mathrm{H}-03,136-138 \mathrm{~cm}$ & 4.37 & 1.07 & 107.5 & 7.035 & 1.890 & 1.161 & 29.304 & 0.127 & 0.020 & 0.042 \\
\hline $722 \mathrm{~B}-1 \mathrm{H}-03,146-148 \mathrm{~cm}$ & 4.47 & 0.96 & 113.1 & 6.109 & 1.466 & 0.970 & 30.622 & 0.103 & 0.021 & 0.046 \\
\hline $722 \mathrm{~B}-1 \mathrm{H}-04,06-08 \mathrm{~cm}$ & 4.57 & 1.04 & 116.8 & 8.802 & 2.347 & 1.479 & 26.922 & 0.161 & 0.025 & 0.048 \\
\hline $722 \mathrm{~B}-1 \mathrm{H}-04,16-18 \mathrm{~cm}$ & 4.67 & 0.96 & 119.8 & 7.644 & 1.927 & 1.188 & 28.259 & 0.128 & 0.026 & 0.048 \\
\hline $722 \mathrm{~B}-1 \mathrm{H}-04,26-28 \mathrm{~cm}$ & 4.77 & 0.98 & 122.8 & 6.105 & 1.552 & 1.009 & 30.683 & 0.099 & 0.023 & 0.040 \\
\hline $722 \mathrm{~B}-1 \mathrm{H}-04,36-38 \mathrm{~cm}$ & 4.87 & 0.86 & 124.1 & 5.635 & 1.411 & 0.911 & 31.310 & 0.093 & 0.025 & 0.040 \\
\hline $722 \mathrm{~B}-1 \mathrm{H}-04,46-48 \mathrm{~cm}$ & 4.97 & 1.07 & 126.0 & 9.234 & 56 & 1.429 & 26. & 0.168 & 0. & 0.051 \\
\hline $722 \mathrm{~B}-1 \mathrm{H}-04,56-58 \mathrm{~cm}$ & 5.07 & 1.05 & 127.5 & 9.281 & 2.456 & 1.499 & 25.765 & 0.169 & 0.029 & 0.052 \\
\hline $722 \mathrm{~B}-1 \mathrm{H}-04,66-68 \mathrm{~cm}$ & 5.17 & 1.11 & 129.2 & 9.206 & 2.382 & 1.416 & 26.319 & 0.165 & 0.032 & 0.056 \\
\hline $722 \mathrm{~B}-1 \mathrm{H}-04,76-78 \mathrm{~cm}$ & 5.27 & 1.01 & 132.0 & 9.444 & 2.452 & 1.499 & 25.551 & 0.171 & 0.029 & 0.058 \\
\hline $722 \mathrm{~B}-2 \mathrm{H}-01,06-08 \mathrm{~cm}$ & 5.62 & 0.93 & 135.8 & 8.235 & 2.123 & 1.505 & 26.966 & 0.149 & 0.023 & 0.051 \\
\hline $722 \mathrm{~B}-2 \mathrm{H}-01,16-18 \mathrm{~cm}$ & 5.67 & 1.00 & 137.1 & 8.436 & 2.145 & 1.419 & 26.834 & 0.151 & 0.027 & 0.050 \\
\hline $722 \mathrm{~B}-2 \mathrm{H}-01,26-28 \mathrm{~cm}$ & 5.77 & 1.04 & 138.2 & 8.978 & 2.265 & 1.417 & 26.477 & 0.158 & 0.027 & 0.051 \\
\hline $722 \mathrm{~B}-2 \mathrm{H}-01,36-38 \mathrm{~cm}$ & 5.87 & 0.89 & 140.5 & 9.584 & 2.442 & 1.437 & 26.022 & 0.170 & 0.030 & 0.048 \\
\hline 722B-2H-01, $46-48 \mathrm{~cm}$ & 5.97 & 1.06 & 142.6 & 9.425 & 2.386 & 1.499 & 25.491 & 0.166 & 0.030 & 0.055 \\
\hline $722 \mathrm{~B}-2 \mathrm{H}-01,56-58 \mathrm{~cm}$ & 6.07 & 1.10 & 144.1 & 9.355 & 2. & 1.597 & 25. & 67 & 0.030 & 0.050 \\
\hline $722 \mathrm{~B}-2 \mathrm{H}-01,66-68 \mathrm{~cm}$ & 6.17 & 1.25 & 145.2 & 9.100 & 2.339 & 1.746 & 25.810 & 0.162 & 0.030 & 0.067 \\
\hline $722 \mathrm{~B}-2 \mathrm{H}-01,76-78 \mathrm{~cm}$ & 6.27 & 1.24 & 147.6 & 11.982 & 3.059 & 1.832 & 22.246 & 0.215 & 0.036 & 0.047 \\
\hline $722 \mathrm{~B}-2 \mathrm{H}-01,86-88 \mathrm{~cm}$ & 6.37 & 1.20 & 149.4 & 12.599 & 3.202 & 1.913 & 21.618 & 0.231 & 0.036 & 0.049 \\
\hline $722 \mathrm{~B}-2 \mathrm{H}-01,96-98 \mathrm{~cm}$ & 6.47 & 1.14 & 151.2 & 11.323 & 2.850 & 1.779 & 23.430 & 0.206 & 0.034 & 0.053 \\
\hline $722 \mathrm{~B}-2 \mathrm{H}-01,106-108 \mathrm{~cm}$ & 6.57 & 1.06 & 152.7 & 11.650 & 2.935 & 1.865 & 22.789 & 0.212 & 0.034 & 0.052 \\
\hline $722 \mathrm{~B}-2 \mathrm{H}-01,116-118 \mathrm{~cm}$ & 6.67 & 1.10 & 154.2 & 11.879 & 3.029 & 1.838 & 22.713 & 0.219 & 0.033 & 0.054 \\
\hline $722 \mathrm{~B}-2 \mathrm{H}-01,126-128 \mathrm{~cm}$ & 6.77 & 1.14 & 156.2 & 12.557 & 3.210 & 1.968 & 21.598 & 0.226 & 0.037 & 0.051 \\
\hline $722 \mathrm{~B}-2 \mathrm{H}-01,136-138 \mathrm{~cm}$ & 6.87 & 1.10 & 158.0 & 11.813 & 3.052 & 1.919 & 22.128 & 0.216 & 0.033 & 0.054 \\
\hline $722 \mathrm{~B}-2 \mathrm{H}-01,146-148 \mathrm{~cm}$ & 6.97 & 1.16 & 159.5 & 12.613 & 3.284 & 1.933 & 21.397 & 0.227 & 0.034 & 0.051 \\
\hline $722 \mathrm{~B}-2 \mathrm{H}-01,06-08 \mathrm{~cm}$ & 7.07 & 1.05 & 161.4 & 11.021 & 2.834 & 1.679 & 23.490 & 0.201 & 0.029 & 0.055 \\
\hline $722 \mathrm{~B}-2 \mathrm{H}-01,16-18 \mathrm{~cm}$ & 7.17 & 1.01 & 163.2 & 10.031 & 2.578 & 1.652 & 25.032 & 0.178 & 0.031 & 0.050 \\
\hline $722 \mathrm{~B}-2 \mathrm{H}-02,26-28 \mathrm{~cm}$ & 7.27 & 1.21 & 165.0 & 10.247 & 2.625 & 1.646 & 24.408 & 0.179 & 0.029 & 0.047 \\
\hline $722 \mathrm{~B}-2 \mathrm{H}-02,36-38 \mathrm{~cm}$ & 7.37 & 1.06 & 166.8 & 9.493 & 2.487 & 1.469 & 25.905 & 0.170 & 0.031 & 0.045 \\
\hline $722 \mathrm{~B}-2 \mathrm{H}-02,46-48 \mathrm{~cm}$ & 7.47 & 1.07 & 168.7 & 10.192 & 2.704 & 1.618 & 24.731 & 0.185 & 0.027 & 0.044 \\
\hline $722 \mathrm{~B}-2 \mathrm{H}-02,56-58 \mathrm{~cm}$ & 7.57 & 1.11 & 170.7 & 10.105 & 2.658 & 1.726 & 24.793 & 0.185 & 0.032 & 0.046 \\
\hline $722 \mathrm{~B}-2 \mathrm{H}-02,66-68 \mathrm{~cm}$ & 7.67 & 1.08 & 172.8 & 10.088 & 2.656 & 1.717 & 24.971 & 0.187 & 0.030 & 0.047 \\
\hline
\end{tabular}


Appendix A (continued).

\begin{tabular}{|c|c|c|c|c|c|c|c|c|c|c|}
\hline $\begin{array}{c}\text { Sample } \\
\text { identification }\end{array}$ & $\begin{array}{l}\text { Depth } \\
\text { (mbsf) }\end{array}$ & $\begin{array}{l}\text { Density } \\
\left(\mathrm{g} / \mathrm{cm}^{3}\right)\end{array}$ & $\begin{array}{l}{ }^{\text {a Age }} \\
\text { (k.y.) }\end{array}$ & $\underset{\text { (wt } \%)}{\mathrm{Si}}$ & $\underset{(w t \%)}{A l}$ & $\underset{(w t \%)}{\mathrm{Fe}}$ & $\underset{(w t \%)}{\mathrm{Ca}}$ & $\underset{(w t \%)}{\mathrm{Ti}}$ & $\underset{(w t \%)}{M n}$ & $\underset{(w t \%)}{P}$ \\
\hline $722 \mathrm{~B}-2 \mathrm{H}-02,76-78 \mathrm{~cm}$ & 7.77 & 1.12 & 175.2 & 8.916 & 2.178 & 1.445 & 26.709 & 0.177 & 0.027 & 0.041 \\
\hline $722 \mathrm{~B}-2 \mathrm{H}-02,86-88 \mathrm{~cm}$ & 7.87 & 1.10 & 177.6 & 9.970 & 2.604 & 1.629 & 25.216 & 0.188 & 0.031 & 0.049 \\
\hline 722B- $2 \mathrm{H}-02,96-98 \mathrm{~cm}$ & 7.97 & 1.13 & 180.0 & 10.263 & 2.666 & 1.715 & 24.421 & 0.194 & 0.031 & 0.050 \\
\hline 722B-2H-02, $106-108 \mathrm{~cm}$ & 8.07 & 1.07 & 182.0 & 10.180 & 2.567 & 1.541 & 25.041 & 0.183 & 0.025 & 0.047 \\
\hline $722 \mathrm{~B}-2 \mathrm{H}-02,116-118 \mathrm{~cm}$ & 8.17 & 1.01 & 184.1 & 10.153 & 2.481 & 1.564 & 25.294 & 0.177 & 0.027 & 0.045 \\
\hline 722B-2H- $02,126-128 \mathrm{~cm}$ & 8.27 & 1.06 & 186.2 & 6.843 & 1.839 & 1.119 & 29.875 & 0.120 & 0.023 & 0.042 \\
\hline $722 \mathrm{~B}-2 \mathrm{H}-02,136-138 \mathrm{~cm}$ & 8.37 & 1.04 & 187.7 & 6.551 & 1.735 & 1.019 & 30.032 & 0.116 & 0.022 & 0.042 \\
\hline $722 \mathrm{~B}-2 \mathrm{H}-02,146-148 \mathrm{~cm}$ & 8.47 & 1.01 & 189.7 & 5.799 & 1.502 & 0.977 & 30.898 & 0.102 & 0.021 & 0.041 \\
\hline $722 \mathrm{~B}-2 \mathrm{H}-03,06-08 \mathrm{~cm}$ & 8.57 & 0.98 & 191.1 & 6.378 & 1.599 & 1.015 & 30.506 & 0.111 & 0.023 & 0.046 \\
\hline $722 \mathrm{~B}-2 \mathrm{H}-03,16-18 \mathrm{~cm}$ & 8.67 & 0.97 & 193.2 & 6.334 & 1.507 & 0.928 & 30.703 & 0.109 & 0.023 & 0.043 \\
\hline $722 \mathrm{~B}-2 \mathrm{H}-03,26-28 \mathrm{~cm}$ & 8.77 & 0.90 & 197.6 & 7.165 & 1.549 & 0.961 & 29.884 & 0.108 & 0.025 & 0.044 \\
\hline $722 \mathrm{~B}-2 \mathrm{H}-03,36-38 \mathrm{~cm}$ & 8.87 & 1.01 & 200.8 & 5.617 & 1.176 & 0.762 & 31.585 & 0.081 & 0.022 & 0.040 \\
\hline $722 \mathrm{~B}-2 \mathrm{H}-03,46-48 \mathrm{~cm}$ & 8.97 & 0.88 & 204.3 & 5.346 & 1.159 & 0.731 & 32.241 & 0.077 & 0.025 & 0.043 \\
\hline $722 \mathrm{~B}-2 \mathrm{H}-03,56-58 \mathrm{~cm}$ & 9.07 & 0.99 & 208.0 & 7.199 & 1.868 & 1.194 & 29.634 & 0.122 & 0.027 & 0.046 \\
\hline $722 \mathrm{~B}-2 \mathrm{H}-03,66-68 \mathrm{~cm}$ & 9.17 & 1.07 & 211.5 & 7.961 & 2.340 & 1.353 & 26.396 & 0.162 & 0.026 & 0.047 \\
\hline 722B-2H-03, 76-78 cm & 9.27 & 1.16 & 215.0 & 10.700 & 2.809 & 1.651 & 22.998 & 0.192 & 0.032 & 0.046 \\
\hline $722 \mathrm{~B}-2 \mathrm{H}-03,86-88 \mathrm{~cm}$ & 9.37 & 1.14 & 218.5 & 10.118 & 2.714 & 1.565 & 26.356 & 0.189 & 0.029 & 0.050 \\
\hline 722B- $2 \mathrm{H}-03,96-98 \mathrm{~cm}$ & 9.47 & 1.05 & 222.1 & 8.080 & 2.175 & 1.393 & 29.185 & 0.160 & 0.030 & 0.053 \\
\hline $722 \mathrm{~B}-2 \mathrm{H}-03,106-108 \mathrm{~cm}$ & 9.57 & 1.06 & 225.8 & 7.968 & 2.152 & 1.466 & 27.398 & 0.150 & 0.027 & 0.050 \\
\hline $722 \mathrm{~B}-2 \mathrm{H}-03,116-118 \mathrm{~cm}$ & 9.67 & 1.13 & 229.8 & 8.684 & 2.362 & 1.598 & 25.956 & 0.162 & 0.030 & 0.048 \\
\hline $722 \mathrm{~B}-2 \mathrm{H}-03,126-128 \mathrm{~cm}$ & 9.77 & 1.08 & 233.4 & 7.694 & 2.006 & 1.190 & 30.153 & 0.140 & 0.025 & 0.049 \\
\hline $722 \mathrm{~B}-2 \mathrm{H}-03,136-138 \mathrm{~cm}$ & 9.87 & 1.05 & 237.0 & 6.425 & 1.623 & 0.999 & 31.277 & 0.111 & 0.023 & 0.049 \\
\hline $722 \mathrm{~B}-2 \mathrm{H}-03,146-148 \mathrm{~cm}$ & 9.97 & 1.02 & 239.0 & 5.256 & 1.315 & 0.815 & 32.903 & 0.087 & 0.023 & 0.046 \\
\hline $722 \mathrm{~B}-2 \mathrm{H}-04,06-08 \mathrm{~cm}$ & 10.07 & 0.98 & 241.0 & 8.154 & 2.145 & 1.476 & 24.239 & 0.148 & 0.026 & 0.044 \\
\hline 722B-2H-04, $16-18 \mathrm{~cm}$ & 10.17 & 0.95 & 242.9 & 7.109 & 1.865 & 1.170 & 29.505 & 0.122 & 0.023 & 0.045 \\
\hline $722 \mathrm{~B}-2 \mathrm{H}-04,26-28 \mathrm{~cm}$ & 10.27 & 0.98 & 244.8 & 7.938 & 2.055 & 1.276 & 29.448 & 0.146 & 0.028 & 0.053 \\
\hline 722B-2H-04, 36-38 cm & 10.37 & 1.04 & 246.3 & 9.253 & 2.415 & 1.366 & 24.736 & 0.166 & 0.029 & 0.047 \\
\hline 722B-2H-04, 46-48 cm & 10.47 & 0.99 & 248.1 & 8.264 & 2.081 & 1.316 & 26.525 & 0.153 & 0.026 & 0.053 \\
\hline $722 \mathrm{~B}-2 \mathrm{H}-04,56-58 \mathrm{~cm}$ & 10.57 & 0.97 & 249.8 & 8.231 & 2.069 & 1.292 & 27.3 & 0.149 & 0.025 & 0.052 \\
\hline 722B-2H-04, 66-68 cm & 10.67 & 0.99 & 251.7 & 8.071 & 1.983 & 1.247 & 27.731 & 0.143 & 0.025 & 0.050 \\
\hline 722B- $2 \mathrm{H}-04,76-78 \mathrm{~cm}$ & 10.77 & 0.91 & 253.2 & 7.864 & 1.617 & 1.034 & 28.682 & 0.115 & 0.022 & 0.045 \\
\hline $722 \mathrm{~B}-2 \mathrm{H}-04,86-88 \mathrm{~cm}$ & 10.87 & 0.90 & 255.0 & 8.507 & 1.620 & 1.047 & 28.061 & 0.115 & 0.023 & 0.045 \\
\hline 722B-2H-04, $96-98 \mathrm{~cm}$ & 10.97 & 0.93 & 256.6 & 8.500 & 1.994 & 1.233 & 27.551 & 0.138 & 0.027 & 0.044 \\
\hline $722 \mathrm{~B}-2 \mathrm{H}-04,106-108 \mathrm{~cm}$ & 11.07 & 1.02 & 258.2 & 8.887 & 2.096 & 1.218 & 27.008 & 0.150 & 0.027 & 0.048 \\
\hline $722 \mathrm{~B}-2 \mathrm{H}-04,116-118 \mathrm{~cm}$ & 11.17 & 1.02 & 259.8 & 8.834 & 2.094 & 1.253 & 26.834 & 0.148 & 0.027 & 0.046 \\
\hline $722 \mathrm{~B}-2 \mathrm{H}-04,126-128 \mathrm{~cm}$ & 11.27 & 1.16 & 261.6 & 10.604 & 2.711 & 1.631 & 25.144 & 0.188 & 0.036 & 0.047 \\
\hline $722 \mathrm{~B}-2 \mathrm{H}-04,136-138 \mathrm{~cm}$ & 11.37 & 1.16 & 263.2 & 10.683 & 2.762 & 1.727 & 25.039 & 0.189 & 0.032 & 0.046 \\
\hline $722 \mathrm{~B}-2 \mathrm{H}-04,146-148 \mathrm{~cm}$ & 11.47 & 1.19 & 265.0 & 11.420 & 3.004 & 1.675 & 23.859 & 0.206 & 0.031 & 0.049 \\
\hline $722 \mathrm{~B}-2 \mathrm{H}-05,06-08 \mathrm{~cm}$ & 11.57 & 1.39 & 266.5 & 10.758 & 2.723 & 1.664 & 24.551 & 0.194 & 0.033 & 0.052 \\
\hline $722 \mathrm{~B}-2 \mathrm{H}-05,16-18 \mathrm{~cm}$ & 11.67 & 1.20 & 268.0 & 10.239 & 2.644 & 1.540 & 25.277 & 0.186 & 0.030 & 0.056 \\
\hline $722 \mathrm{~B}-2 \mathrm{H}-05,26-28 \mathrm{~cm}$ & 11.77 & 1.14 & 271.5 & 9.652 & 2.471 & 1.558 & 26.132 & 0.180 & 0.026 & 0.049 \\
\hline 722B-2H-05, 36-38 cm & 11.87 & 1.14 & 277.0 & 10.505 & 2.728 & 1.620 & 24.207 & 0.194 & 0.029 & 0.054 \\
\hline $722 \mathrm{~B}-2 \mathrm{H}-05,46-48 \mathrm{~cm}$ & 11.97 & 1.03 & 281.5 & 6.963 & 1.654 & 1.052 & 29.662 & 0.116 & 0.022 & 0.043 \\
\hline $722 \mathrm{~B}-2 \mathrm{H}-05,56-58 \mathrm{~cm}$ & 12.07 & 1.07 & 286.0 & 4.899 & 1.207 & 0.748 & 32.520 & 0.079 & 0.020 & 0.037 \\
\hline $722 \mathrm{~B}-2 \mathrm{H}-05,66-68 \mathrm{~cm}$ & 12.17 & 1.07 & 289.0 & 5.587 & 1.478 & 0.865 & 31.766 & 0.100 & 0.021 & 0.039 \\
\hline 722B-2H-05, 76-78 cm & 12.27 & 1.1 & 292.0 & 5.445 & 1.453 & 0.902 & 31.812 & 0.101 & 0.022 & 0.042 \\
\hline $722 \mathrm{~B}-2 \mathrm{H}-05,86-88 \mathrm{~cm}$ & 12.37 & 1.12 & 295.0 & 5.758 & 1.529 & 0.997 & 30.904 & 0.108 & 0.021 & 0.040 \\
\hline $722 \mathrm{~B}-2 \mathrm{H}-05,96-98 \mathrm{~cm}$ & 12.47 & 1.09 & 298.0 & 6.451 & 1.646 & 1.067 & 30.024 & 0.123 & 0.024 & 0.044 \\
\hline $722 \mathrm{~B}-2 \mathrm{H}-05,106-108 \mathrm{~cm}$ & 12.57 & 1.09 & 302.0 & 5.929 & 1.522 & 0.916 & 30.899 & 0.110 & 0.021 & 0.042 \\
\hline $722 \mathrm{~B}-2 \mathrm{H}-05,116-118 \mathrm{~cm}$ & 12.67 & 1.01 & 306.0 & 5.230 & 1.358 & 0.849 & 32.940 & 0.093 & 0.023 & 0.044 \\
\hline $722 \mathrm{~B}-2 \mathrm{H}-05,126-128 \mathrm{~cm}$ & 12.77 & 1.05 & 310.0 & 6.533 & 1.489 & 0.955 & 29.403 & 0.106 & 0.020 & 0.039 \\
\hline $722 \mathrm{~B}-2 \mathrm{H}-05,136-138 \mathrm{~cm}$ & 12.87 & 1.10 & 314.0 & 4.479 & 1.121 & 0.700 & 32.847 & 0.076 & 0.017 & 0.041 \\
\hline $722 \mathrm{~B}-2 \mathrm{H}-05,146-148 \mathrm{~cm}$ & 12.97 & 1.12 & 318.0 & 5.365 & 1.424 & 0.853 & 31.943 & 0.095 & 0.018 & 0.046 \\
\hline 722B-2H-06, 06-08 cm & 13.07 & 1.06 & 322 & 5.795 & 1.543 & 0.969 & 31. & 0.107 & 0.020 & 0.053 \\
\hline $722 \mathrm{~B}-2 \mathrm{H}-06,16-18 \mathrm{~cm}$ & 13.17 & 1.03 & 326.0 & 5.048 & 1.242 & 0.780 & 32.510 & 0.087 & 0.020 & 0.050 \\
\hline 722B-2H-06, 26- $28 \mathrm{~cm}$ & 13.27 & 0.98 & & 5.453 & 1.165 & 0.748 & 32.112 & 0.083 & 0.020 & 0.043 \\
\hline $722 \mathrm{~B}-2 \mathrm{H}-06,36-38 \mathrm{~cm}$ & 13.37 & 1.01 & 331.5 & 4.718 & 1.156 & 0.709 & 32.903 & 0.076 & 0.018 & 0.042 \\
\hline $722 \mathrm{~B}-2 \mathrm{H}-06,46-48 \mathrm{~cm}$ & 13.47 & 1.02 & & 5.170 & 1.362 & 0.828 & & 0.086 & & 0.049 \\
\hline $722 \mathrm{~B}-2 \mathrm{H}-06,56-58 \mathrm{~cm}$ & 13.57 & 1.06 & 334.6 & 6.000 & 1.553 & 0.992 & 30.762 & 0.103 & 0.024 & 0.043 \\
\hline 722B-2H-06, 66-68 cm & 13.67 & 1. & 336.1 & 6.082 & 1.643 & 0.991 & & 0.113 & & 0.042 \\
\hline $722 \mathrm{~B}-2 \mathrm{H}-06,76-78 \mathrm{~cm}$ & 13.77 & 1.10 & 337.6 & 6.833 & 1.837 & 1.240 & 28.810 & 0.126 & 0.028 & 0.044 \\
\hline $722 \mathrm{~B}-2 \mathrm{H}-06,86-88 \mathrm{~cm}$ & 13.87 & 1.11 & 338.8 & 6.961 & 1.840 & 1.119 & 29.125 & 0.126 & 0.028 & 0.044 \\
\hline 722B-2H-06, 96-98 cm & 13.9 & 1.12 & 340.8 & 8.84 & 2.30 & 1.347 & 30.093 & 0.160 & 0.032 & 0.052 \\
\hline $722 \mathrm{~B}-2 \mathrm{H}-06,106-108 \mathrm{~cm}$ & 14.07 & 0.9 & 342.8 & 8.108 & & 1.207 & 28.116 & 0.148 & 0.026 & 0.047 \\
\hline $722 \mathrm{~B}-2 \mathrm{H}-06,116-118 \mathrm{~cm}$ & 14.1 & 1.0 & 344. & 7.58 & 1.9 & 1.211 & 28.292 & 0.140 & 0.027 & 0.057 \\
\hline $722 \mathrm{~B}-2 \mathrm{H}-06,126-128 \mathrm{~cm}$ & 14.27 & 1.1 & 347.0 & 7.960 & 2.028 & 1.199 & 28.049 & 0.146 & 0.027 & 0.054 \\
\hline $722 \mathrm{~B}-2 \mathrm{H}-06,136-138 \mathrm{~cm}$ & 14.3 & 1.0 & 349 & 7.488 & 1.849 & 1.204 & 28.465 & 0.134 & 0.026 & 0.048 \\
\hline $722 \mathrm{~B}-2 \mathrm{H}-06,146-148 \mathrm{~cm}$ & 14.47 & 1.05 & 351.6 & 7.524 & 1.905 & 1.205 & 28.725 & 0.135 & 0.024 & 0.049 \\
\hline 722B-2H-07, 06-08 cm & 14.57 & 1.0 & 353 & 7.83 & 1.982 & 1.287 & 28.236 & 0.139 & 0.024 & 0.055 \\
\hline 722B-2H-07, 16-18 cm & 14.67 & 1.0 & 356.0 & 7.887 & 2.043 & 1.153 & 28.200 & 0.140 & 0.025 & 0.043 \\
\hline $722 \mathrm{~B}-2 \mathrm{H}-07,26-28 \mathrm{~cm}$ & 14. & 1.1 & 360.5 & 8.76 & 2.27 & 1.475 & & 0.155 & 0.030 & 0.043 \\
\hline $722 \mathrm{~B}-2 \mathrm{H}-07,36-38 \mathrm{~cm}$ & 14.87 & 1.11 & 365.0 & 8.573 & 2.212 & 1.252 & 27.747 & 0.153 & 0.027 & 0.042 \\
\hline
\end{tabular}

a Chronostratigraphy from Clemens and Prell, pers. comm., March 1989. 
APPENDIX B

Hole 722B Cores $1 \mathrm{H}$ and $2 \mathrm{H}$ Corrected for Salt Contribution and Dilution.

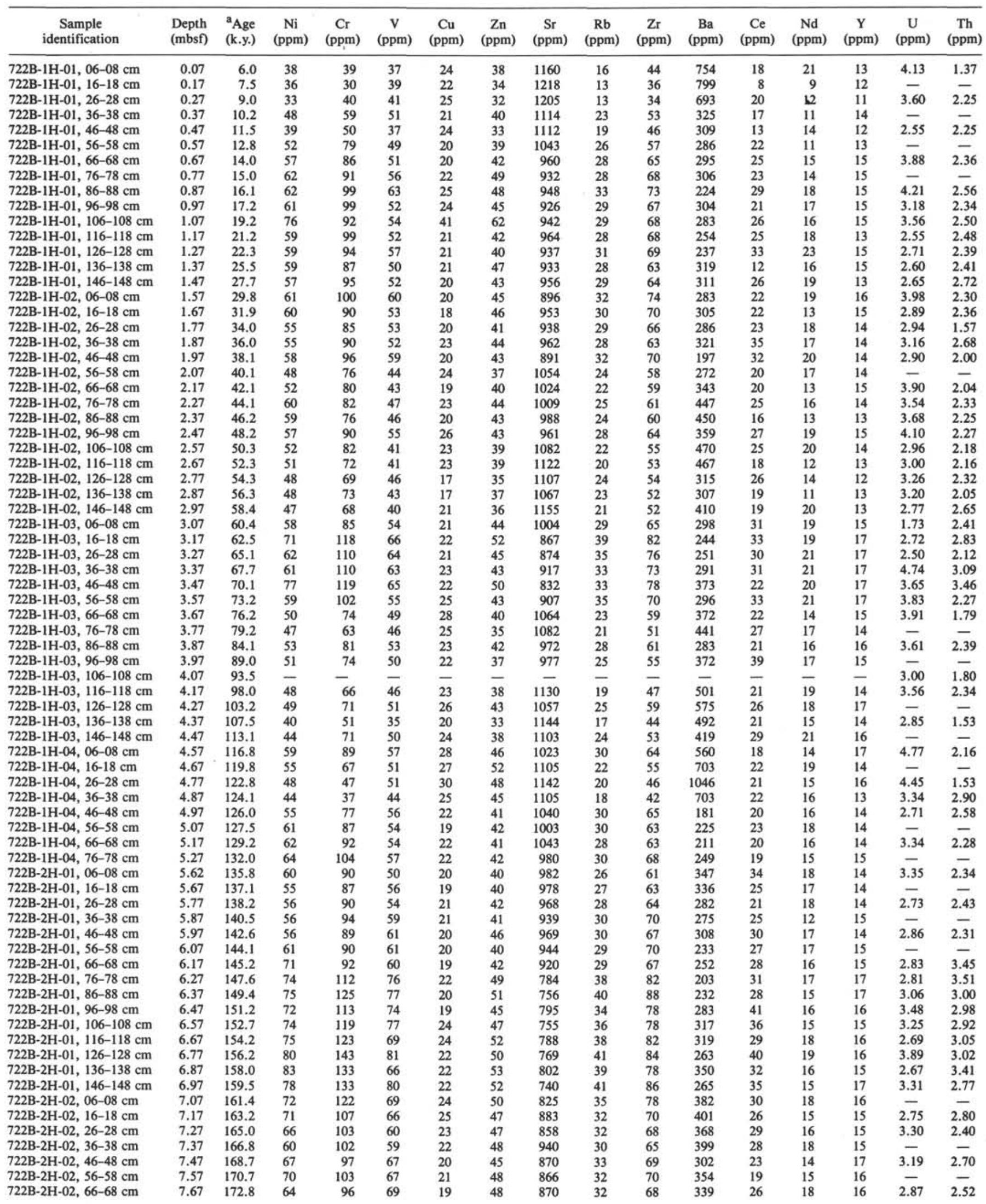


Appendix B (continued).

\begin{tabular}{|c|c|c|c|c|c|c|c|c|c|c|c|c|c|c|c|c|}
\hline $\begin{array}{c}\text { Sample } \\
\text { identification }\end{array}$ & $\begin{array}{l}\text { Depth } \\
\text { (mbsf) }\end{array}$ & $\begin{array}{l}{ }^{a} \text { Age } \\
\text { (k.y.) }\end{array}$ & $\underset{(\mathrm{ppm})}{\mathrm{Ni}}$ & $\underset{(\mathrm{ppm})}{\mathrm{Cr}}$ & $\underset{(p p m)}{V}$ & $\underset{(\mathrm{ppm})}{\mathrm{Cu}}$ & $\underset{(\mathrm{ppm})}{\mathrm{Zn}}$ & $\begin{array}{c}\mathrm{Sr} \\
(\mathrm{ppm})\end{array}$ & $\underset{(\mathrm{ppm})}{\mathrm{Rb}}$ & $\begin{array}{c}\mathrm{Zr} \\
\text { (ppm) }\end{array}$ & $\begin{array}{c}\mathrm{Ba} \\
(\mathrm{ppm})\end{array}$ & $\begin{array}{c}\mathrm{Ce} \\
(\mathrm{ppm})\end{array}$ & $\begin{array}{l}\mathrm{Nd} \\
\text { (ppm) }\end{array}$ & $\underset{(\mathrm{ppm})}{\mathrm{Y}}$ & $\underset{(\mathrm{ppm})}{U}$ & $\begin{array}{c}\text { Th } \\
\text { (ppm) }\end{array}$ \\
\hline $722 \mathrm{~B}-2 \mathrm{H}-02,76-78 \mathrm{~cm}$ & 7.77 & 175.2 & 57 & 127 & 52 & 19 & 40 & 870 & 26 & 94 & 259 & 25 & 17 & 15 & - & - \\
\hline $722 \mathrm{~B}-2 \mathrm{H}-02,86-88 \mathrm{~cm}$ & 7.87 & 177.6 & 65 & 96 & 69 & 27 & 45 & 931 & 32 & 67 & 359 & 27 & 17 & 16 & 4.11 & 3.07 \\
\hline $722 \mathrm{~B}-2 \mathrm{H}-02,96-98 \mathrm{~cm}$ & 7.97 & 180.0 & 73 & 121 & 66 & 31 & 52 & 903 & 32 & 74 & 424 & 34 & 14 & 18 & - & - \\
\hline $722 \mathrm{~B}-2 \mathrm{H}-02,106-108 \mathrm{~cm}$ & 8.07 & 182.0 & 69 & 108 & 63 & 26 & 51 & 934 & 30 & 70 & 518 & 21 & 15 & 17 & 3.04 & 2.39 \\
\hline $722 \mathrm{~B}-2 \mathrm{H}-02,116-118 \mathrm{~cm}$ & 8.17 & 184.1 & 71 & 97 & 57 & 25 & 49 & 940 & 30 & 68 & 582 & 25 & 19 & 17 & - & - \\
\hline $722 \mathrm{~B}-2 \mathrm{H}-02,126-128 \mathrm{~cm}$ & 8.27 & 186.2 & 48 & 54 & 53 & 29 & 41 & 1113 & 23 & 45 & 645 & 29 & 21 & 16 & 2.81 & - \\
\hline $722 \mathrm{~B}-2 \mathrm{H}-02,136-138 \mathrm{~cm}$ & 8.37 & 187.7 & 42 & 57 & 49 & 26 & 41 & 1134 & 21 & 44 & 540 & 22 & 16 & 16 & - & - \\
\hline $722 \mathrm{~B}-2 \mathrm{H}-02,146-148 \mathrm{~cm}$ & 8.47 & 189.7 & 40 & 50 & 48 & 27 & 37 & 1179 & 20 & 40 & 521 & 14 & 15 & 14 & 2.28 & - \\
\hline $722 \mathrm{~B}-2 \mathrm{H}-03,06-08 \mathrm{~cm}$ & 8.57 & 191.1 & 44 & 56 & 45 & 24 & 41 & 1228 & 18 & 44 & 550 & 12 & 17 & 14 & - & - \\
\hline $722 \mathrm{~B}-2 \mathrm{H}-03,16-18 \mathrm{~cm}$ & 8.67 & 193.2 & 42 & 52 & 44 & 26 & 34 & 1256 & 19 & 42 & 548 & 25 & 20 & 13 & 2.73 & - \\
\hline $722 \mathrm{~B}-2 \mathrm{H}-03,26-28 \mathrm{~cm}$ & 8.77 & 197.6 & 47 & 56 & 52 & 22 & 40 & 1171 & 17 & 46 & 687 & 29 & 18 & 14 & - & - \\
\hline $722 \mathrm{~B}-2 \mathrm{H}-03,36-38 \mathrm{~cm}$ & 8.87 & 200.8 & 38 & 37 & 39 & 24 & 39 & 1224 & 14 & 35 & 737 & 15 & 16 & 12 & 3.13 & 1.27 \\
\hline $722 \mathrm{~B}-2 \mathrm{H}-03,46-48 \mathrm{~cm}$ & 8.97 & 204.3 & 36 & 31 & 38 & 20 & 36 & 1277 & 13 & 33 & 714 & 6 & 11 & 12 & - & - \\
\hline $722 \mathrm{~B}-2 \mathrm{H}-03,56-58 \mathrm{~cm}$ & 9.07 & 208.0 & 51 & 59 & 46 & 25 & 42 & 1167 & 23 & 48 & 446 & 12 & 15 & 13 & 1.81 & 2.40 \\
\hline 722B-2H-03, 66-68 cm & 9.17 & 211.5 & 57 & 77 & 56 & 20 & 41 & 1003 & 29 & 57 & 281 & 27 & 17 & 13 & - & - \\
\hline 722B- $2 \mathrm{H}-03,76-78 \mathrm{~cm}$ & 9.27 & 215.0 & 62 & 107 & 75 & 25 & 45 & 842 & 36 & 71 & 265 & 25 & 16 & 16 & 3.20 & 2.70 \\
\hline $722 \mathrm{~B}-2 \mathrm{H}-03,86-88 \mathrm{~cm}$ & 9.37 & 218.5 & 63 & 97 & 77 & 27 & 46 & 1013 & 34 & 70 & 323 & 20 & 12 & 17 & - & - \\
\hline 722B-2H-03, 96-98 cm & 9.47 & 222.1 & 66 & 82 & 49 & 30 & 45 & 1162 & 26 & 59 & 516 & 16 & 16 & 16 & 4.18 & 2.58 \\
\hline $722 \mathrm{~B}-2 \mathrm{H}-03,106-108 \mathrm{~cm}$ & 9.57 & 225.8 & 63 & 81 & 56 & 28 & 43 & 1121 & 26 & 56 & 380 & 30 & 12 & 15 & - & - \\
\hline $722 \mathrm{~B}-2 \mathrm{H}-03,116-118 \mathrm{~cm}$ & 9.67 & 229.8 & 69 & 85 & 63 & 25 & 44 & 1039 & 28 & 59 & 421 & 27 & 18 & 16 & 3.62 & 2.13 \\
\hline $722 \mathrm{~B}-2 \mathrm{H}-03,126-128 \mathrm{~cm}$ & 9.77 & 233.4 & 51 & 75 & 55 & 25 & 44 & 1201 & 23 & 55 & 524 & 31 & 18 & 17 & - & - \\
\hline $722 \mathrm{~B}-2 \mathrm{H}-03,136-138 \mathrm{~cm}$ & 9.87 & 237.0 & 43 & 54 & 43 & 25 & 38 & 1252 & 19 & 47 & 573 & 20 & 16 & 15 & 2.41 & 1.37 \\
\hline $722 \mathrm{~B}-2 \mathrm{H}-03,146-148 \mathrm{~cm}$ & 9.97 & 239.0 & 37 & 38 & 36 & 23 & 34 & 1310 & 15 & 39 & 602 & 17 & 14 & 13 & - & - \\
\hline 722B-2H-04, 06-08 cm & 10.07 & 241.0 & 38 & 55 & 40 & 22 & 33 & 944 & 19 & 39 & 326 & 23 & 12 & 11 & - & - \\
\hline $722 \mathrm{~B}-2 \mathrm{H}-04,16-18 \mathrm{~cm}$ & 10.17 & 242.9 & - & 90 & 55 & 29 & 39 & 1027 & 30 & 75 & 242 & 19 & 13 & 14 & - & - \\
\hline $722 \mathrm{~B}-2 \mathrm{H}-04,26-28 \mathrm{~cm}$ & 10.27 & 244.8 & 52 & 78 & 53 & 22 & 43 & 1105 & 25 & 60 & 417 & 34 & 19 & 14 & - & - \\
\hline $722 \mathrm{~B}-2 \mathrm{H}-04,36-38 \mathrm{~cm}$ & 10.37 & 246.3 & 53 & 91 & 55 & 18 & 39 & 937 & 30 & 68 & 263 & 28 & 12 & 14 & - & - \\
\hline $722 \mathrm{~B}-2 \mathrm{H}-04,46-48 \mathrm{~cm}$ & 10.47 & 248.1 & 52 & 87 & 52 & 23 & 40 & 1020 & 26 & 62 & 379 & 29 & 13 & 13 & - & - \\
\hline $722 \mathrm{~B}-2 \mathrm{H}-04,56-58 \mathrm{~cm}$ & 10.57 & 249.8 & 52 & 92 & 47 & 22 & 40 & 1026 & 25 & 62 & 376 & 26 & 15 & 14 & - & - \\
\hline $722 \mathrm{~B}-2 \mathrm{H}-04,66-68 \mathrm{~cm}$ & 10.67 & 251.7 & 51 & 76 & 52 & 22 & 40 & 1058 & 24 & 58 & 398 & 16 & 15 & 14 & - & - \\
\hline $722 \mathrm{~B}-2 \mathrm{H}-04,76-78 \mathrm{~cm}$ & 10.77 & 253.2 & 45 & 63 & 48 & 19 & 35 & 1117 & 18 & 49 & 450 & 25 & 14 & 13 & - & - \\
\hline $722 \mathrm{~B}-2 \mathrm{H}-04,86-88 \mathrm{~cm}$ & 10.87 & 255.0 & 43 & 71 & 42 & 19 & 34 & 1088 & 19 & 54 & 454 & 22 & 16 & 12 & - & - \\
\hline $722 \mathrm{~B}-2 \mathrm{H}-04,96-98 \mathrm{~cm}$ & 10.97 & 256.6 & 51 & 72 & 52 & 20 & 38 & 1070 & 25 & 59 & 369 & 16 & 14 & 13 & - & - \\
\hline $722 \mathrm{~B}-2 \mathrm{H}-04,106-108 \mathrm{~cm}$ & 11.07 & 258.2 & 51 & 82 & 54 & 20 & 40 & 1080 & 26 & 60 & 402 & 25 & 14 & 13 & - & - \\
\hline $722 \mathrm{~B}-2 \mathrm{H}-04,116-118 \mathrm{~cm}$ & 11.17 & 259.8 & 54 & 74 & 53 & 21 & 41 & 1067 & 26 & 62 & 375 & 23 & 17 & 13 & - & - \\
\hline $722 \mathrm{~B}-2 \mathrm{H}-04,126-128 \mathrm{~cm}$ & 11.27 & 261.6 & 60 & 95 & 59 & 20 & 42 & 977 & 34 & 73 & 262 & 39 & 15 & 15 & - & - \\
\hline $722 \mathrm{~B}-2 \mathrm{H}-04,136-138 \mathrm{~cm}$ & 11.37 & 263.2 & 64 & 92 & 64 & 19 & 46 & 981 & 35 & 75 & 209 & 27 & 16 & 17 & - & - \\
\hline $722 \mathrm{~B}-2 \mathrm{H}-04,146-148 \mathrm{~cm}$ & 11.47 & 265.0 & 61 & 89 & 67 & 21 & 45 & 954 & 34 & 76 & 259 & 24 & 16 & 17 & - & - \\
\hline $722 \mathrm{~B}-2 \mathrm{H}-05,06-08 \mathrm{~cm}$ & 11.57 & 266.5 & 63 & 99 & 80 & 25 & 46 & 948 & 35 & 77 & 356 & 15 & 18 & 17 & - & - \\
\hline $722 \mathrm{~B}-2 \mathrm{H}-05,16-18 \mathrm{~cm}$ & 11.67 & 268.0 & 61 & 102 & 66 & 23 & 48 & 991 & 32 & 73 & 364 & 23 & 16 & 18 & - & - \\
\hline $722 \mathrm{~B}-2 \mathrm{H}-05,26-28 \mathrm{~cm}$ & 11.77 & 271.5 & 66 & 111 & 72 & 26 & 49 & 987 & 36 & 80 & 330 & 29 & 15 & 19 & - & - \\
\hline $722 \mathrm{~B}-2 \mathrm{H}-05,36-38 \mathrm{~cm}$ & 11.87 & 277.0 & 65 & 94 & 61 & 21 & 42 & 987 & 28 & 77 & 383 & 20 & 17 & 15 & - & - \\
\hline $722 \mathrm{~B}-2 \mathrm{H}-05,46-48 \mathrm{~cm}$ & 11.97 & 281.5 & 45 & 57 & 49 & 23 & 40 & 1227 & 19 & 61 & 514 & 23 & 21 & 14 & - & - \\
\hline $722 \mathrm{~B}-2 \mathrm{H}-05,56-58 \mathrm{~cm}$ & 12.07 & 286.0 & 31 & 30 & 37 & 24 & 32 & 1442 & 14 & 43 & 498 & 21 & 20 & 13 & - & - \\
\hline $722 \mathrm{~B}-2 \mathrm{H}-05,66-68 \mathrm{~cm}$ & 12.17 & 289.0 & 33 & 41 & 39 & 22 & 31 & 1359 & 18 & 49 & 242 & 22 & 15 & 13 & - & - \\
\hline $722 \mathrm{~B}-2 \mathrm{H}-05,76-78 \mathrm{~cm}$ & 12.27 & 292.0 & 37 & 44 & 47 & 21 & 29 & 1364 & 17 & 49 & 348 & 11 & 15 & 14 & - & - \\
\hline $722 \mathrm{~B}-2 \mathrm{H}-05,86-88 \mathrm{~cm}$ & 12.37 & 295.0 & 39 & 53 & 43 & 22 & 28 & 1333 & 18 & 54 & 253 & 12 & 13 & 15 & - & - \\
\hline 722B-2H-05, 96-98 cm & 12.47 & 298.0 & 51 & 76 & 39 & 26 & 36 & 1255 & 19 & 60 & 493 & 10 & 8 & 15 & - & - \\
\hline $722 \mathrm{~B}-2 \mathrm{H}-05,106-108 \mathrm{~cm}$ & 12.57 & 302.0 & 42 & 63 & 49 & 27 & 37 & 1348 & 17 & 55 & 439 & 19 & 11 & 12 & - & - \\
\hline $722 \mathrm{~B}-2 \mathrm{H}-05,116-118 \mathrm{~cm}$ & 12.67 & 306.0 & 44 & 59 & 41 & 28 & 37 & 1398 & 18 & 60 & 605 & 18 & 12 & 14 & - & - \\
\hline $722 \mathrm{~B}-2 \mathrm{H}-05,126-128 \mathrm{~cm}$ & 12.77 & 310.0 & 38 & 39 & 33 & 21 & 27 & 1335 & 14 & 48 & 383 & 21 & 17 & 13 & - & - \\
\hline $722 \mathrm{~B}-2 \mathrm{H}-05,136-138 \mathrm{~cm}$ & 12.87 & 314.0 & 34 & 33 & 33 & 21 & 28 & 1424 & 13 & 48 & 368 & 22 & 16 & 13 & - & - \\
\hline 722B-2H-05, 146-148 cm & 12.97 & 318.0 & 32 & 37 & 42 & 26 & 31 & 1352 & 16 & 53 & 425 & 20 & 16 & 15 & - & - \\
\hline $722 \mathrm{~B}-2 \mathrm{H}-06,06-08 \mathrm{~cm}$ & 13.07 & 322.0 & 37 & 48 & 47 & 25 & 34 & 1340 & 19 & 56 & 391 & 12 & 7 & 15 & - & - \\
\hline $722 \mathrm{~B}-2 \mathrm{H}-06,16-18 \mathrm{~cm}$ & 13.17 & 326.0 & 33 & 40 & 38 & 27 & 29 & 1431 & 14 & 52 & 524 & 14 & 16 & 13 & - & - \\
\hline $722 \mathrm{~B}-2 \mathrm{H}-06,26-28 \mathrm{~cm}$ & 13.27 & 330.0 & 35 & 40 & 33 & 20 & 27 & 1441 & 12 & 51 & 502 & 6 & 11 & 12 & - & - \\
\hline $722 \mathrm{~B}-2 \mathrm{H}-06,36-38 \mathrm{~cm}$ & 13.37 & 331.5 & 32 & 35 & 35 & 21 & 36 & 1489 & 12 & 49 & 582 & 12 & 12 & 12 & - & - \\
\hline $722 \mathrm{~B}-2 \mathrm{H}-06,46-48 \mathrm{~cm}$ & 13.47 & 333.1 & 32 & 40 & 31 & 24 & 30 & 1381 & 15 & 53 & 449 & 25 & 18 & 14 & - & - \\
\hline $722 \mathrm{~B}-2 \mathrm{H}-06,56-58 \mathrm{~cm}$ & 13.57 & 334.6 & 39 & 48 & 36 & 23 & 35 & 1283 & 19 & 56 & 301 & 18 & 18 & 12 & - & - \\
\hline $722 \mathrm{~B}-2 \mathrm{H}-06,66-68 \mathrm{~cm}$ & 13.67 & 336.1 & 37 & 52 & 37 & 17 & 25 & 1364 & 19 & 58 & 120 & 17 & 19 & 10 & - & - \\
\hline $722 \mathrm{~B}-2 \mathrm{H}-06,76-78 \mathrm{~cm}$ & 13.77 & 337.6 & 45 & 59 & 40 & 20 & 29 & 1266 & 22 & 63 & 118 & 26 & 13 & 11 & - & - \\
\hline $722 \mathrm{~B}-2 \mathrm{H}-06,86-88 \mathrm{~cm}$ & 13.87 & 338.8 & 41 & 64 & 41 & 15 & 27 & 1271 & 22 & 62 & 183 & 17 & 11 & 12 & - & - \\
\hline 722B- $2 \mathrm{H}-06,96-98 \mathrm{~cm}$ & 13.97 & 340.8 & 50 & 95 & 51 & 25 & 38 & 1245 & 28 & 75 & 186 & 17 & 15 & 14 & - & - \\
\hline $722 \mathrm{~B}-2 \mathrm{H}-06,106-108 \mathrm{~cm}$ & 14.07 & 342.8 & 59 & 71 & 51 & 17 & 35 & 1183 & 26 & 71 & 222 & 31 & 16 & 14 & - & - \\
\hline $722 \mathrm{~B}-2 \mathrm{H}-06,116-118 \mathrm{~cm}$ & 14.17 & 344.8 & 49 & 81 & 50 & 21 & 41 & 1140 & 23 & 69 & 334 & 16 & 15 & 15 & - & - \\
\hline $722 \mathrm{~B}-2 \mathrm{H}-06,126-128 \mathrm{~cm}$ & 14.27 & 347.0 & 46 & 75 & 46 & 19 & 35 & 1149 & 25 & 73 & 319 & 20 & 11 & 14 & - & - \\
\hline $722 \mathrm{~B}-2 \mathrm{H}-06,136-138 \mathrm{~cm}$ & 14.37 & 349.2 & 46 & 71 & 47 & 21 & 33 & 1166 & 22 & 68 & 351 & 24 & 13 & 14 & - & - \\
\hline $722 \mathrm{~B}-2 \mathrm{H}-06,146-148 \mathrm{~cm}$ & 14.47 & 351.6 & 45 & 63 & 49 & 19 & 34 & 1205 & 23 & 65 & 341 & 31 & 16 & 12 & - & - \\
\hline $722 \mathrm{~B}-2 \mathrm{H}-07,06-08 \mathrm{~cm}$ & 14.57 & 353.7 & 49 & 67 & 50 & 18 & 35 & 1183 & 25 & 71 & 360 & 21 & 13 & 13 & - & - \\
\hline $722 \mathrm{~B}-2 \mathrm{H}-07,16-18 \mathrm{~cm}$ & 14.67 & 356.0 & 45 & 61 & 51 & 17 & 33 & 1208 & 25 & 70 & 227 & 23 & 14 & 12 & - & - \\
\hline $722 \mathrm{~B}-2 \mathrm{H}-07,26-28 \mathrm{~cm}$ & 14.77 & 360.5 & 55 & 73 & 56 & 19 & 34 & 1115 & 29 & 73 & 237 & 23 & 13 & 14 & - & - \\
\hline $722 \mathrm{~B}-2 \mathrm{H}-07,36-38 \mathrm{~cm}$ & 14.87 & 365.0 & 46 & 72 & 53 & 20 & 36 & 1136 & 29 & 73 & 260 & 23 & 19 & 14 & - & - \\
\hline
\end{tabular}

- Missing data or no data available.

a Chronostratigraphy from Clemens and Prell, pers. comm., March 1989. 
APPENDIX C

Hole 724C Major Element Analyses. Corrected for Salt Contribution and Dilution.

\begin{tabular}{|c|c|c|c|c|c|c|c|c|c|c|c|c|}
\hline $\begin{array}{c}\text { Sample } \\
\text { identification }\end{array}$ & $\begin{array}{l}\text { Depth } \\
\text { (mbsf) }\end{array}$ & $\begin{array}{l}{ }^{\mathrm{a}} \text { Age } \\
\text { (k.y.) }\end{array}$ & $\begin{array}{c}\mathrm{Si} \\
(w t \%)\end{array}$ & $\begin{array}{c}\mathrm{Al} \\
(\mathrm{wt} \%)\end{array}$ & $\underset{\text { (wt } \%)}{\mathrm{Fe}}$ & $\begin{array}{c}\mathrm{Mg} \\
(\mathrm{wt} \%)\end{array}$ & $\underset{(\mathrm{wt} \%)}{\mathrm{Ca}}$ & $\underset{(\mathrm{wt} \%)}{\mathrm{Na}}$ & $\underset{(w t \%)}{K}$ & $\underset{(w t \%)}{T i}$ & $\underset{(w t \%)}{\operatorname{Mn}}$ & $\underset{(w t \%)}{P}$ \\
\hline $724 \mathrm{C}-1 \mathrm{H}-01,25-27 \mathrm{~cm}$ & 0.25 & 6.1 & 11.94 & 2.12 & 0.90 & 1.12 & 21.97 & 1.05 & 0.57 & 0.164 & 0.025 & 0.445 \\
\hline $724 \mathrm{C}-1 \mathrm{H}-01,45-47 \mathrm{~cm}$ & 0.45 & 7.5 & 10.66 & 1.97 & 0.87 & 0.99 & 24.63 & 0.72 & 0.52 & 0.156 & 0.022 & 0.221 \\
\hline $724 C-1 \mathrm{H}-01,65-67 \mathrm{~cm}$ & 0.65 & 8.8 & 12.12 & 2.23 & 0.98 & 1.50 & 22.78 & 0.84 & 0.61 & 0.180 & 0.027 & 0.099 \\
\hline $724 \mathrm{C}-1 \mathrm{H}-01,85-87 \mathrm{~cm}$ & 0.85 & 10.1 & 11.93 & 2.22 & 0.98 & 1.51 & 22.65 & 0.87 & 0.62 & 0.180 & 0.031 & 0.091 \\
\hline $724 \mathrm{C}-1 \mathrm{H}-01,105-107 \mathrm{~cm}$ & 1.05 & 11.5 & 11.74 & 2.29 & 1.13 & 1.69 & 22.76 & 0.81 & 0.64 & 0.193 & 0.032 & 0.105 \\
\hline $724 \mathrm{C}-1 \mathrm{H}-01,125-127 \mathrm{~cm}$ & 1.25 & 12.8 & 13.98 & 2.64 & 1.28 & 2.04 & 20.85 & 0.90 & 0.74 & 0.222 & 0.036 & 0.073 \\
\hline $724 \mathrm{C}-1 \mathrm{H}-01,145-147 \mathrm{~cm}$ & 1.45 & 14.1 & 14.08 & 2.73 & 1.34 & 2.14 & 19.95 & 0.81 & 0.77 & 0.222 & 0.036 & 0.076 \\
\hline $724 \mathrm{C}-1 \mathrm{H}-02,15-17 \mathrm{~cm}$ & 1.65 & 15.5 & 14.12 & 2.75 & 1.42 & 2.09 & 19.13 & 0.88 & 0.78 & 0.231 & 0.037 & 0.081 \\
\hline $724 \mathrm{C}-1 \mathrm{H}-02,35-37 \mathrm{~cm}$ & 1.85 & 16.8 & 14.42 & 2.86 & 1.48 & 2.18 & 19.25 & 0.93 & 0.80 & 0.241 & 0.037 & 0.092 \\
\hline $724 \mathrm{C}-1 \mathrm{H}-02,55-57 \mathrm{~cm}$ & 2.05 & 18.1 & 14.61 & 2.99 & 1.60 & 2.25 & 18.64 & 0.84 & 0.86 & 0.241 & 0.033 & 0.102 \\
\hline $724 \mathrm{C}-1 \mathrm{H}-02,75-77 \mathrm{~cm}$ & 2.25 & 19.5 & 13.90 & 2.90 & 1.51 & 2.22 & 19.65 & 0.79 & 0.81 & 0.238 & 0.036 & 0.155 \\
\hline $724 \mathrm{C}-1 \mathrm{H}-02,95-97 \mathrm{~cm}$ & 2.45 & 20.8 & 14.04 & 2.98 & 1.71 & 2.22 & 19.28 & 0.85 & 0.83 & 0.244 & 0.037 & 0.155 \\
\hline $724 \mathrm{C}-2 \mathrm{H}-01,10-12 \mathrm{~cm}$ & 2.90 & 23.8 & 13.88 & 2.64 & 1.30 & 2.02 & 20.78 & 0.83 & 0.73 & 0.223 & 0.036 & 0.086 \\
\hline $724 \mathrm{C}-2 \mathrm{H}-01,25-27 \mathrm{~cm}$ & 3.05 & 25.3 & 14.22 & 2.87 & 1.48 & 2.03 & 19.67 & 0.86 & 0.78 & 0.240 & 0.038 & 0.142 \\
\hline $724 \mathrm{C}-2 \mathrm{H}-01,45-47 \mathrm{~cm}$ & 3.25 & 27.6 & 14.02 & 2.82 & 1.54 & 2.07 & 19.46 & 1.02 & 0.78 & 0.239 & 0.038 & 0.105 \\
\hline $724 \mathrm{C}-2 \mathrm{H}-01,65-67 \mathrm{~cm}$ & 3.45 & 29.8 & 15.46 & 3.20 & 1.73 & 2.31 & 17.14 & 1.11 & 0.95 & 0.262 & 0.037 & 0.113 \\
\hline $724 \mathrm{C}-2 \mathrm{H}-01,85-87 \mathrm{~cm}$ & 3.65 & 32.1 & 15.11 & 2.99 & 1.56 & 2.23 & 19.00 & 0.82 & 0.82 & 0.251 & 0.040 & 0.142 \\
\hline $724 \mathrm{C}-2 \mathrm{H}-01,105-107 \mathrm{~cm}$ & 3.85 & 34.3 & 14.80 & 2.88 & 1.47 & 1.95 & 19.71 & 0.81 & 0.80 & 0.247 & 0.036 & 0.083 \\
\hline $724 \mathrm{C}-2 \mathrm{H}-01,125-127 \mathrm{~cm}$ & 4.05 & 36.6 & 19.84 & 4.22 & 2.34 & 2.76 & 12.15 & 1.21 & 1.16 & 0.326 & 0.040 & 0.157 \\
\hline $724 \mathrm{C}-2 \mathrm{H}-01,145-147 \mathrm{~cm}$ & 4.25 & 38.8 & 15.56 & 3.08 & 1.62 & 2.22 & 19.19 & 0.89 & 0.85 & 0.254 & 0.042 & 0.095 \\
\hline $724 \mathrm{C}-2 \mathrm{H}-02,15-17 \mathrm{~cm}$ & 4.45 & 41.1 & 16.00 & 3.17 & 1.62 & 2.25 & 19.06 & 1.01 & 0.86 & 0.260 & 0.042 & 0.106 \\
\hline $724 \mathrm{C}-2 \mathrm{H}-02,35-37 \mathrm{~cm}$ & 4.65 & 43.3 & 15.19 & 3.06 & 1.65 & 2.11 & 17.85 & 0.90 & 0.83 & 0.254 & 0.035 & 0.121 \\
\hline $724 \mathrm{C}-2 \mathrm{H}-02,55-57 \mathrm{~cm}$ & 4.85 & 45.5 & 14.81 & 2.93 & 1.58 & 2.03 & 18.60 & 0.93 & 0.79 & 0.243 & 0.038 & 0.126 \\
\hline $724 \mathrm{C}-2 \mathrm{H}-02,75-77 \mathrm{~cm}$ & 5.05 & 47.8 & 13.25 & 2.76 & 1.47 & 1.85 & 20.36 & 0.77 & 0.74 & 0.225 & 0.036 & 0.147 \\
\hline $724 \mathrm{C}-2 \mathrm{H}-02,95-97 \mathrm{~cm}$ & 5.25 & 50.0 & 14.42 & 2.91 & 1.55 & 2.06 & 19.44 & 0.96 & 0.78 & 0.246 & 0.040 & 0.120 \\
\hline $724 \mathrm{C}-2 \mathrm{H}-02,115-117 \mathrm{~cm}$ & 5.45 & 52.3 & 15.74 & 3.11 & 1.64 & 2.12 & 18.69 & 1.00 & 0.84 & 0.268 & 0.036 & 0.157 \\
\hline $724 \mathrm{C}-2 \mathrm{H}-02,135-137 \mathrm{~cm}$ & 5.65 & 54.5 & 13.53 & 2.92 & 1.57 & 2.05 & 20.13 & 0.86 & 0.77 & 0.232 & 0.034 & 0.151 \\
\hline $724 \mathrm{C}-2 \mathrm{H}-03,05-07 \mathrm{~cm}$ & 5.85 & 56.8 & 14.47 & 2.97 & 1.64 & 2.31 & 19.86 & 0.82 & 0.83 & 0.252 & 0.041 & 0.064 \\
\hline $724 \mathrm{C}-2 \mathrm{H}-03,25-27 \mathrm{~cm}$ & 6.05 & 59.0 & 14.06 & 2.89 & 1.50 & 1.36 & 20.95 & 0.22 & 0.76 & 0.247 & 0.037 & 0.085 \\
\hline $724 \mathrm{C}-2 \mathrm{H}-03,45-47 \mathrm{~cm}$ & 6.25 & 61.1 & 13.68 & 2.84 & 1.54 & 2.10 & 20.51 & 0.94 & 0.79 & 0.237 & 0.038 & 0.064 \\
\hline $724 \mathrm{C}-2 \mathrm{H}-03,65-67 \mathrm{~cm}$ & 6.45 & 63.2 & 13.35 & 2.80 & 1.57 & 2.39 & 20.41 & 1.17 & 0.79 & 0.235 & 0.035 & 0.064 \\
\hline $724 \mathrm{C}-2 \mathrm{H}-03,85-87 \mathrm{~cm}$ & 6.65 & 65.3 & 13.66 & 2.76 & 1.43 & 1.89 & 19.89 & 0.85 & 0.75 & 0.234 & 0.036 & 0.094 \\
\hline $724 \mathrm{C}-2 \mathrm{H}-03,105-107 \mathrm{~cm}$ & 6.85 & 67.4 & 14.86 & 2.95 & 1.47 & 2.10 & 20.38 & 0.92 & 0.79 & 0.243 & 0.037 & 0.103 \\
\hline $724 \mathrm{C}-2 \mathrm{H}-03,125-127 \mathrm{~cm}$ & 7.05 & 69.5 & 14.37 & 2.85 & 1.47 & 1.97 & 19.74 & 0.82 & 0.76 & 0.240 & 0.035 & 0.113 \\
\hline $724 \mathrm{C}-2 \mathrm{H}-03,145-147 \mathrm{~cm}$ & 7.25 & 71.6 & 15.67 & 3.24 & 1.75 & 2.12 & 17.40 & 0.89 & 0.86 & 0.267 & 0.038 & 0.117 \\
\hline $724 \mathrm{C}-2 \mathrm{H}-04,15-17 \mathrm{~cm}$ & 7.45 & 73.7 & 13.44 & 2.80 & 1.41 & 1.84 & 20.42 & 0.96 & 0.75 & 0.220 & 0.031 & 0.130 \\
\hline $724 \mathrm{C}-2 \mathrm{H}-04,35-37 \mathrm{~cm}$ & 7.65 & 75.8 & 12.29 & 2.45 & 1.15 & 1.45 & 22.44 & 0.89 & 0.65 & 0.196 & 0.031 & 0.225 \\
\hline $724 \mathrm{C}-2 \mathrm{H}-04,55-57 \mathrm{~cm}$ & 7.85 & 77.9 & 9.53 & 1.94 & 0.84 & 1.01 & 25.68 & 0.85 & 0.51 & 0.157 & 0.023 & 0.292 \\
\hline $724 \mathrm{C}-2 \mathrm{H}-04,75-77 \mathrm{~cm}$ & 8.05 & 80.0 & 11.57 & 2.35 & 1.13 & 1.45 & 23.15 & 0.89 & 0.63 & 0.194 & 0.028 & 0.148 \\
\hline $724 \mathrm{C}-2 \mathrm{H}-04,95-97 \mathrm{~cm}$ & 8.25 & 86.0 & 12.15 & 2.45 & 1.15 & 1.10 & 23.02 & 0.53 & 0.63 & 0.207 & 0.033 & 0.155 \\
\hline $724 \mathrm{C}-2 \mathrm{H}-04,115-117 \mathrm{~cm}$ & 8.45 & 92.0 & 10.50 & 2.19 & 1.03 & 1.28 & 24.37 & 0.84 & 0.56 & 0.178 & 0.025 & 0.196 \\
\hline $724 \mathrm{C}-2 \mathrm{H}-04,135-137 \mathrm{~cm}$ & 8.65 & 98.0 & 9.92 & 2.06 & 0.93 & 1.18 & 25.62 & 0.72 & 0.53 & 0.164 & 0.026 & 0.167 \\
\hline $724 \mathrm{C}-2 \mathrm{H}-05,05-07 \mathrm{~cm}$ & 8.85 & 104.0 & 11.15 & 2.22 & 1.00 & 1.50 & 25.52 & 0.97 & 0.59 & 0.177 & 0.027 & 0.169 \\
\hline $724 \mathrm{C}-2 \mathrm{H}-05,25-27 \mathrm{~cm}$ & 9.05 & 110.0 & 11.06 & 2.21 & 1.06 & 1.33 & 24.68 & 0.73 & 0.59 & 0.181 & 0.029 & 0.218 \\
\hline $724 \mathrm{C}-2 \mathrm{H}-05,45-47 \mathrm{~cm}$ & 9.25 & 116.0 & 10.96 & 2.12 & 0.96 & 1.36 & 23.83 & 0.73 & 0.57 & 0.174 & 0.026 & 0.135 \\
\hline $724 \mathrm{C}-2 \mathrm{H}-05,65-67 \mathrm{~cm}$ & 9.45 & 122.0 & 12.25 & 2.35 & 1.07 & 1.70 & 22.82 & 0.85 & 0.63 & 0.195 & 0.031 & 0.099 \\
\hline $724 \mathrm{C}-2 \mathrm{H}-05,85-85 \mathrm{~cm}$ & 9.65 & 123.2 & 12.42 & 2.33 & 1.06 & 1.62 & 20.14 & 0.88 & 0.64 & 0.188 & 0.034 & 0.073 \\
\hline $724 \mathrm{C}-2 \mathrm{H}-05,105-107 \mathrm{~cm}$ & 9.85 & 124.4 & 12.97 & 2.55 & 1.22 & 1.97 & 21.38 & 0.88 & 0.70 & 0.206 & 0.034 & 0.066 \\
\hline $724 \mathrm{C}-2 \mathrm{H}-05,125-127 \mathrm{~cm}$ & 10.05 & 125.5 & 13.83 & 2.69 & 1.29 & 2.07 & 20.70 & 0.89 & 0.74 & 0.221 & 0.037 & 0.060 \\
\hline $724 \mathrm{C}-2 \mathrm{H}-05,145-147 \mathrm{~cm}$ & 10.25 & 126.7 & 12.42 & 2.47 & 1.27 & 2.01 & 21.01 & 0.55 & 0.70 & 0.206 & 0.038 & 0.053 \\
\hline $724 \mathrm{C}-2 \mathrm{H}-06,15-17 \mathrm{~cm}$ & 10.45 & 127.9 & 14.01 & 2.67 & 1.32 & 2.09 & 20.71 & 0.91 & 0.74 & 0.225 & 0.035 & 0.058 \\
\hline $724 \mathrm{C}-2 \mathrm{H}-06,35-37 \mathrm{~cm}$ & 10.65 & 129.1 & 14.22 & 2.76 & 1.36 & 2.14 & 20.40 & 0.86 & 0.76 & 0.233 & 0.038 & 0.060 \\
\hline $724 \mathrm{C}-2 \mathrm{H}-06,55-57 \mathrm{~cm}$ & 10.85 & 130.3 & 14.00 & 2.87 & 1.53 & 2.42 & 20.05 & 0.88 & 0.81 & 0.233 & 0.037 & 0.066 \\
\hline $724 \mathrm{C}-2 \mathrm{H}-06,75-77 \mathrm{~cm}$ & 11.05 & 131.5 & 14.27 & 2.96 & 1.57 & 2.37 & 19.78 & 0.91 & 0.82 & 0.236 & 0.038 & 0.067 \\
\hline $724 \mathrm{C}-2 \mathrm{H}-06,95-97 \mathrm{~cm}$ & 11.25 & 132.6 & 14.38 & 2.93 & 1.57 & 2.39 & 19.57 & 0.73 & 0.84 & 0.241 & 0.038 & 0.063 \\
\hline $724 \mathrm{C}-2 \mathrm{H}-06,115-117 \mathrm{~cm}$ & 11.45 & 133.8 & 14.84 & 3.06 & 1.59 & 2.59 & 18.09 & 1.18 & 0.87 & 0.238 & 0.037 & 0.081 \\
\hline $724 \mathrm{C}-2 \mathrm{H}-06,135-137 \mathrm{~cm}$ & 11.65 & 135.0 & 14.91 & 3.03 & 1.49 & 2.23 & 18.90 & 0.83 & 0.86 & 0.240 & 0.038 & 0.072 \\
\hline $724 \mathrm{C}-2 \mathrm{H}-07,05-07 \mathrm{~cm}$ & 11.85 & 137.8 & 15.18 & 3.07 & 1.53 & 2.37 & 19.24 & 0.79 & 0.88 & 0.244 & 0.039 & 0.075 \\
\hline $724 \mathrm{C}-2 \mathrm{H}-07,25-27 \mathrm{~cm}$ & 12.05 & 140.5 & 15.32 & 3.02 & 1.51 & 2.27 & 18.86 & 0.92 & 0.86 & 0.240 & 0.039 & 0.072 \\
\hline $724 \mathrm{C}-2 \mathrm{H}-07,45-47 \mathrm{~cm}$ & 12.25 & 143.3 & 14.88 & 3.06 & 1.62 & 2.33 & 18.57 & 0.95 & 0.87 & 0.250 & 0.037 & 0.080 \\
\hline $724 \mathrm{C}-2 \mathrm{H}-07,60-62 \mathrm{~cm}$ & 12.40 & 146.1 & 15.02 & 3.11 & 1.58 & 2.32 & 18.73 & 0.82 & 0.89 & 0.248 & 0.040 & 0.064 \\
\hline $724 \mathrm{C}-3 \mathrm{H}-01,25-27 \mathrm{~cm}$ & 12.45 & 146.7 & 14.88 & 3.08 & 1.58 & 2.27 & 18.46 & 0.92 & 0.87 & 0.247 & 0.042 & 0.064 \\
\hline $724 \mathrm{C}-3 \mathrm{H}-01,45-47 \mathrm{~cm}$ & 12.65 & 148.8 & 13.99 & 2.92 & 1.50 & 2.29 & 19.85 & 0.89 & 0.82 & 0.234 & 0.033 & 0.090 \\
\hline $724 \mathrm{C}-3 \mathrm{H}-01,65-67 \mathrm{~cm}$ & 12.85 & 151.6 & 13.88 & 2.95 & 1.69 & 2.35 & 19.52 & 0.82 & 0.84 & 0.235 & 0.040 & 0.070 \\
\hline $724 \mathrm{C}-3 \mathrm{H}-01,85-87 \mathrm{~cm}$ & 13.05 & 154.4 & 14.12 & 2.98 & 1.55 & 2.36 & 19.56 & 0.75 & 0.83 & 0.238 & 0.038 & 0.067 \\
\hline $724 \mathrm{C}-3 \mathrm{H}-01,105-107 \mathrm{~cm}$ & 13.25 & 157.2 & 13.88 & 2.92 & 1.51 & 2.31 & 19.79 & 0.79 & 0.80 & 0.244 & 0.037 & 0.075 \\
\hline $724 \mathrm{C}-3 \mathrm{H}-01,125-127 \mathrm{~cm}$ & 13.45 & 159.9 & 14.14 & 2.95 & 1.55 & 2.29 & 19.86 & 0.87 & 0.82 & 0.241 & 0.039 & 0.067 \\
\hline $724 \mathrm{C}-3 \mathrm{H}-01,145-147 \mathrm{~cm}$ & 13.65 & 162.7 & 13.94 & 2.94 & 1.56 & 2.31 & 19.79 & 0.80 & 0.81 & 0.241 & 0.040 & 0.072 \\
\hline $724 \mathrm{C}-3 \mathrm{H}-02,15-17 \mathrm{~cm}$ & 13.85 & 165.5 & 13.72 & 2.95 & 1.63 & 2.36 & 19.80 & 0.81 & 0.82 & 0.237 & 0.041 & 0.067 \\
\hline $724 \mathrm{C}-3 \mathrm{H}-02,35-37 \mathrm{~cm}$ & 14.05 & 168.2 & 13.82 & 2.94 & 1.60 & 2.26 & 19.96 & 0.76 & 0.81 & 0.235 & 0.034 & 0.095 \\
\hline $724 \mathrm{C}-3 \mathrm{H}-02,55-57 \mathrm{~cm}$ & 14.25 & 171.0 & 14.30 & 2.97 & 1.59 & 2.29 & 19.62 & 0.86 & 0.82 & 0.242 & 0.036 & 0.060 \\
\hline $724 \mathrm{C}-3 \mathrm{H}-02,75-77 \mathrm{~cm}$ & 14.45 & 172.5 & 14.50 & 3.04 & 1.59 & 2.37 & 19.47 & 0.77 & 0.83 & 0.244 & 0.036 & 0.057 \\
\hline $724 \mathrm{C}-3 \mathrm{H}-02,95-97 \mathrm{~cm}$ & 14.65 & 174.0 & 13.53 & 2.81 & 1.55 & 2.23 & 18.85 & 0.87 & 0.83 & 0.238 & 0.039 & 0.052 \\
\hline $724 \mathrm{C}-3 \mathrm{H}-02,115-117 \mathrm{~cm}$ & 14.85 & 175.5 & 14.68 & 3.04 & 1.63 & 2.37 & 19.11 & 0.85 & 0.85 & 0.254 & 0.042 & 0.054 \\
\hline $724 \mathrm{C}-3 \mathrm{H}-02,135-137 \mathrm{~cm}$ & 15.05 & 177.0 & 14.79 & 3.08 & 1.63 & 2.34 & 18.71 & 0.86 & 0.86 & 0.253 & 0.039 & 0.062 \\
\hline $724 \mathrm{C}-3 \mathrm{H}-03,05-07 \mathrm{~cm}$ & 15.25 & 178.5 & 14.27 & 2.98 & 1.65 & 2.28 & 18.26 & 0.85 & 0.86 & 0.253 & 0.039 & 0.059 \\
\hline $724 \mathrm{C}-3 \mathrm{H}-03,25-27 \mathrm{~cm}$ & 15.45 & 180.0 & 14.79 & 3.12 & 1.70 & 2.37 & 18.63 & 0.75 & 0.87 & 0.257 & 0.039 & 0.071 \\
\hline
\end{tabular}


Appendic C (continued).

\begin{tabular}{|c|c|c|c|c|c|c|c|c|c|c|c|c|}
\hline $\begin{array}{c}\text { Sample } \\
\text { identification }\end{array}$ & $\begin{array}{l}\text { Depth } \\
\text { (mbsf) }\end{array}$ & $\begin{array}{l}{ }^{\text {a Age }} \\
\text { (k.y.) }\end{array}$ & $\underset{(w t \%)}{\mathrm{Si}}$ & $\underset{(w t \%)}{\mathrm{Al}}$ & $\underset{(w t \%)}{\mathrm{Fe}}$ & $\underset{\text { (wt \%) }}{\mathbf{M g}_{0}}$ & $\underset{(w t \%)}{\mathrm{Ca}}$ & $\begin{array}{c}\mathrm{Na} \\
(w t \%)\end{array}$ & $\underset{(w t \%)}{K}$ & $\underset{(w t \%)}{\mathrm{Ti}}$ & $\underset{\text { (wt\%) }}{\mathrm{Mn}}$ & $\underset{\text { (wt\%) }}{\stackrel{P}{P}}$ \\
\hline $724 \mathrm{C}-3 \mathrm{H}-03,45-47 \mathrm{~cm}$ & 15.65 & 181.5 & 15.80 & 3.44 & 1.91 & 2.22 & 18.32 & 0.56 & 0.94 & 0.269 & 0.044 & 0.076 \\
\hline $724 \mathrm{C}-3 \mathrm{H}-03,65-67 \mathrm{~cm}$ & 15.85 & 183.0 & 14.91 & 3.32 & 1.84 & 2.50 & 17.46 & 0.77 & 0.93 & 0.263 & 0.038 & 0.077 \\
\hline $724 \mathrm{C}-3 \mathrm{H}-03,85-87 \mathrm{~cm}$ & 16.05 & 185.1 & 14.88 & 3.25 & 1.86 & 2.54 & 17.99 & 0.82 & 0.91 & 0.263 & 0.041 & 0.075 \\
\hline $724 \mathrm{C}-3 \mathrm{H}-03,105-107 \mathrm{~cm}$ & 16.25 & 187.2 & 16.79 & 3.65 & 2.00 & 2.69 & 15.16 & 0.98 & 1.02 & 0.291 & 0.042 & 0.087 \\
\hline $724 \mathrm{C}-3 \mathrm{H}-03,125-127 \mathrm{~cm}$ & 16.45 & 189.3 & 19.34 & 4.17 & 2.34 & 3.25 & 21.68 & 1.27 & 1.17 & 0.321 & 0.051 & 0.084 \\
\hline $724 \mathrm{C}-3 \mathrm{H}-03,145-147 \mathrm{~cm}$ & 16.65 & 191.5 & 15.17 & 3.32 & 1.90 & 2.53 & 17.87 & 0.88 & 0.93 & 0.265 & 0.042 & 0.071 \\
\hline $724 \mathrm{C}-3 \mathrm{H}-04,15-17 \mathrm{~cm}$ & 16.85 & 193.6 & 15.50 & 3.33 & 1.86 & 2.48 & 17.80 & 0.96 & 0.94 & 0.270 & 0.041 & 0.063 \\
\hline $724 \mathrm{C}-3 \mathrm{H}-04,35-37 \mathrm{~cm}$ & 17.05 & 195.7 & 15.48 & 3.38 & 1.92 & 2.49 & 17.84 & 0.84 & 0.93 & 0.272 & 0.044 & 0.059 \\
\hline $724 \mathrm{C}-3 \mathrm{H}-04,55-57 \mathrm{~cm}$ & 17.25 & 197.8 & 17.21 & 3.88 & 2.14 & 2.79 & 14.69 & 1.01 & 1.08 & 0.308 & 0.046 & 0.077 \\
\hline $724 \mathrm{C}-3 \mathrm{H}-04,75-77 \mathrm{~cm}$ & 17.45 & 199.9 & 15.31 & 3.38 & 1.88 & 2.45 & 17.36 & 0.74 & 0.95 & 0.265 & 0.042 & 0.059 \\
\hline $724 \mathrm{C}-3 \mathrm{H}-04,95-97 \mathrm{~cm}$ & 17.65 & 202.0 & 15.34 & 3.32 & 1.83 & 2.44 & 18.10 & 0.90 & 0.92 & 0.267 & 0.045 & 0.067 \\
\hline $724 \mathrm{C}-3 \mathrm{H}-04,115-117 \mathrm{~cm}$ & 17.85 & 204.2 & 15.26 & 3.40 & 1.91 & 2.55 & 17.49 & 0.92 & 0.94 & 0.269 & 0.044 & 0.068 \\
\hline $724 \mathrm{C}-3 \mathrm{H}-04,135-137 \mathrm{~cm}$ & 18.05 & 206.3 & 16.19 & 3.60 & 2.02 & 2.50 & 16.09 & 0.93 & 0.97 & 0.278 & 0.039 & 0.097 \\
\hline $724 \mathrm{C}-3 \mathrm{H}-05,05-07 \mathrm{~cm}$ & 18.25 & 208.4 & 15.87 & 3.42 & 1.97 & 2.38 & 16.89 & 1.03 & 0.93 & 0.280 & 0.041 & 0.089 \\
\hline $724 \mathrm{C}-3 \mathrm{H}-05,25-27 \mathrm{~cm}$ & 18.45 & 210.5 & 14.09 & 3.10 & 1.75 & 2.28 & 19.37 & 1.00 & 0.84 & 0.251 & 0.040 & 0.292 \\
\hline $724 \mathrm{C}-3 \mathrm{H}-05,45-47 \mathrm{~cm}$ & 18.65 & 212.6 & 14.11 & 3.13 & 1.73 & 2.14 & 19.25 & 0.82 & 0.85 & 0.251 & 0.038 & 0.097 \\
\hline $724 \mathrm{C}-3 \mathrm{H}-05,65-67 \mathrm{~cm}$ & 18.85 & 214.7 & 14.53 & 3.12 & 1.71 & 2.21 & 19.06 & 0.86 & 0.85 & 0.248 & 0.040 & 0.102 \\
\hline $724 \mathrm{C}-3 \mathrm{H}-05,85-87 \mathrm{~cm}$ & 19.05 & 216.8 & 13.20 & 2.90 & 1.68 & 2.14 & 19.12 & 0.78 & 0.83 & 0.259 & 0.038 & 0.074 \\
\hline $724 \mathrm{C}-3 \mathrm{H}-05,105-107 \mathrm{~cm}$ & 19.25 & 219.0 & 13.54 & 3.01 & 1.70 & 2.09 & 19.71 & 0.89 & 0.82 & & & 0.092 \\
\hline $724 \mathrm{C}-3 \mathrm{H}-05,125-127 \mathrm{~cm}$ & 19.45 & 221.1 & 14.15 & 3.04 & 1.64 & 2.14 & 19.04 & 0.92 & 0.81 & 0.247 & 0.034 & 0.126 \\
\hline $724 \mathrm{C}-3 \mathrm{H}-05,145-147 \mathrm{~cm}$ & 19.65 & 223.2 & 14.62 & 3.11 & 1.68 & 2.22 & 18.98 & 0.83 & 0.85 & 0.256 & 0.038 & 0.129 \\
\hline $724 \mathrm{C}-3 \mathrm{H}-06,15-17 \mathrm{~cm}$ & 19.85 & 225.3 & 14.21 & 3.10 & 1.70 & 2.21 & 18.95 & 0.97 & 0.83 & 0.248 & 0.034 & 0.166 \\
\hline $724 \mathrm{C}-3 \mathrm{H}-06,35-37 \mathrm{~cm}$ & 20.05 & 227.4 & 9.10 & 2.02 & 1.01 & 1.21 & & 0.70 & 53 & & & 0.289 \\
\hline $724 \mathrm{C}-3 \mathrm{H}-06,55-57 \mathrm{~cm}$ & 20.25 & 229.5 & 9.90 & 2.17 & 1.15 & 1.32 & 24.00 & 0.72 & 0.58 & 0.176 & 0.024 & 0.494 \\
\hline $724 \mathrm{C}-3 \mathrm{H}-06,75-77 \mathrm{~cm}$ & 20.45 & 231.7 & 11.25 & 2.46 & 1.29 & 1.54 & & 0.83 & 0.66 & & & 0.269 \\
\hline $724 \mathrm{C}-3 \mathrm{H}-06,95-97 \mathrm{~cm}$ & 20.65 & 233.8 & 6.85 & 1.57 & 0.79 & 0.97 & 28.27 & 0.63 & 0.41 & 0.128 & 0.020 & 0.547 \\
\hline $724 \mathrm{C}-3 \mathrm{H}-06,115-117 \mathrm{~cm}$ & 20.85 & 235.9 & 10.41 & 2.39 & 1.30 & 1.66 & & 0.69 & 0.66 & & & 0.134 \\
\hline $724 \mathrm{C}-3 \mathrm{H}-06,135-137 \mathrm{~cm}$ & 21.05 & 238.0 & 11.29 & 2.58 & 1.43 & 1.77 & 22.57 & 0.72 & 0.71 & 0.204 & 0.031 & 0.080 \\
\hline $724 \mathrm{C}-3 \mathrm{H}-07,05-07 \mathrm{~cm}$ & 21.25 & 239.2 & 12.42 & 2.72 & 1.45 & 1.82 & 21.70 & 0.70 & 0.75 & & & 0.084 \\
\hline $724 \mathrm{C}-3 \mathrm{H}-07,25-27 \mathrm{~cm}$ & 21.45 & 240.3 & 12.73 & 2.67 & 1.40 & 1.83 & 21.30 & 0.84 & 0.74 & 0.227 & 0.035 & 0.089 \\
\hline $724 \mathrm{C}-3 \mathrm{H}-07,45-47 \mathrm{~cm}$ & 21.65 & 241.5 & 12.88 & 2.71 & 1.42 & 1.75 & 21.14 & 0.77 & 0.73 & & 0.031 & 0.153 \\
\hline $724 \mathrm{C}-3 \mathrm{H}-07,65-67 \mathrm{~cm}$ & 21.83 & 242.5 & 12.02 & 2.53 & 1.28 & 1.63 & 21.83 & 0.83 & 0.68 & 0.207 & 0.028 & 0.207 \\
\hline $724 \mathrm{C}-4 \mathrm{H}-01,13-15 \mathrm{~cm}$ & 21.85 & 242.6 & 12.41 & 2.40 & 1.15 & 1.58 & 22.37 & 0.78 & 0.65 & 0.204 & 0.028 & 0.104 \\
\hline $724 \mathrm{C}-4 \mathrm{H}-01,25-27 \mathrm{~cm}$ & 21.95 & 243.2 & 12.04 & 2.38 & 1.20 & 1.54 & 22.64 & 0.73 & 0.65 & 0.201 & 0.029 & 0.125 \\
\hline $724 \mathrm{C}-4 \mathrm{H}-01,45-47 \mathrm{~cm}$ & 22.15 & 244.4 & 12.80 & 2.51 & 1.26 & 1.66 & 21.23 & 0.78 & 0.72 & 0.219 & 0.031 & 0.091 \\
\hline $724 \mathrm{C}-4 \mathrm{H}-01,65-67 \mathrm{~cm}$ & 22.35 & 2455 & 14.79 & 2.97 & 1.50 & 2.09 & 19.17 & 0.90 & 0.83 & 0.249 & 0.034 & 0.079 \\
\hline $724 \mathrm{C}-4 \mathrm{H}-01,85-85 \mathrm{~cm}$ & 22.55 & 246.7 & 15.21 & 3.16 & 1.68 & 2.26 & 18.19 & 0.85 & 0.89 & 0.260 & 0.038 & 0.080 \\
\hline $724 \mathrm{C}-4 \mathrm{H}-01,105-107 \mathrm{~cm}$ & 22.75 & 2478 & 15.60 & 3.27 & 1.73 & 2.36 & 16.83 & 0.96 & 0.93 & 0.265 & 0.032 & 0.087 \\
\hline $724 \mathrm{C}-4 \mathrm{H}-01,125-127 \mathrm{~cm}$ & 22.95 & 249.0 & 14.10 & 3.03 & 1.68 & 2.09 & 18.92 & 0.88 & 0.85 & 0.242 & 0.032 & 0.090 \\
\hline $724 \mathrm{C}-4 \mathrm{H}-01,145-147 \mathrm{~cm}$ & 23.15 & 254.4 & 16.10 & 3.22 & 1.69 & 2.34 & 17.13 & 100 & 0.90 & 0.281 & 0.035 & 0.094 \\
\hline $724 \mathrm{C}-4 \mathrm{H}-02,15-17 \mathrm{~cm}$ & 23.35 & 259.9 & 14.89 & 3.03 & 1.64 & 2.17 & 18.42 & 0.90 & 0.85 & 0.255 & 0.035 & 0.093 \\
\hline $724 \mathrm{C}-4 \mathrm{H}-02,35-37 \mathrm{~cm}$ & 23.55 & 265.3 & 14.67 & 3.05 & 1.72 & 2.18 & 18.25 & 088 & 0.84 & 0.251 & 0.032 & 0.127 \\
\hline $724 \mathrm{C}-4 \mathrm{H}-02,55-57 \mathrm{~cm}$ & 23.75 & 270.7 & 14.64 & 3.09 & 1.63 & 2.21 & 19.09 & 0.77 & 0.87 & 0.251 & 0.039 & 0.102 \\
\hline $724 \mathrm{C}-4 \mathrm{H}-02,75-77 \mathrm{~cm}$ & 23.95 & 276.1 & 14.12 & 3.03 & 1.61 & 2.18 & 19.38 & 0.82 & & 0.245 & 0.033 & 0.091 \\
\hline $724 \mathrm{C}-4 \mathrm{H}-02,95-97 \mathrm{~cm}$ & 24.15 & 281.6 & 14.57 & 3.14 & 1.8 & 2.27 & 19.14 & 0.78 & 0.88 & 0.251 & 0.038 & 0.095 \\
\hline $724 \mathrm{C}-4 \mathrm{H}-02,115-117 \mathrm{~cm}$ & 24.35 & 287.0 & 14.51 & 3.13 & 1.72 & 2.27 & 18.98 & 0.93 & 0.88 & 0.254 & 0.036 & 0.092 \\
\hline $724 \mathrm{C}-4 \mathrm{H}-02,135-137 \mathrm{~cm}$ & 24.55 & 289.2 & 12.73 & 2.78 & 1.5 & 2.10 & 21.27 & 0.76 & 0.79 & 0.226 & 0.033 & 0.057 \\
\hline $724 \mathrm{C}-4 \mathrm{H}-03,05-07 \mathrm{~cm}$ & 24.75 & 291.4 & 13.01 & 2.85 & 1.5 & 2.15 & 2105 & 0.76 & & 0.230 & 0.035 & 0.066 \\
\hline $724 \mathrm{C}-4 \mathrm{H}-03,25-27 \mathrm{~cm}$ & 24.95 & 293.6 & 12.80 & 2.72 & 1.4 & 1.90 & 21.23 & 0.82 & 0.75 & 0.221 & 0.031 & 0.077 \\
\hline $724 \mathrm{C}-4 \mathrm{H}-03,45-47 \mathrm{~cm}$ & 25 & 295.8 & 12.63 & 2.68 & 1.39 & 1.97 & 21.52 & 0.77 & 0.77 & 0.220 & 0.034 & 0.065 \\
\hline $724 \mathrm{C}-4 \mathrm{H}-03,65-67 \mathrm{~cm}$ & 25.35 & 298.0 & 12.24 & 2.66 & 1.4 & 1.99 & 21.71 & 0.75 & 0.7 & 0.216 & 0.033 & 0.058 \\
\hline $724 \mathrm{C}-4 \mathrm{H}-03,85-87 \mathrm{~cm}$ & 25.55 & 300.2 & 12.00 & 2.57 & 1.3 & 1.83 & 21.36 & 0.77 & 0.75 & 0.212 & 0.031 & 0.062 \\
\hline $724 \mathrm{C}-4 \mathrm{H}-03,105-107 \mathrm{~cm}$ & 25.75 & 302.4 & 13.1 & 2.79 & 1.4 & 1.79 & 22.46 & 0.8 & 0.75 & 0.227 & 0.031 & 0.095 \\
\hline $724 \mathrm{C}-4 \mathrm{H}-03,125-127 \mathrm{~cm}$ & 25.95 & 304.6 & 12.30 & 2.61 & 1.3 & 1.61 & & 0.7 & 0. & & 0.031 & 0.099 \\
\hline $724 \mathrm{C}-4 \mathrm{H}-03,145-147 \mathrm{~cm}$ & 26.15 & 306.8 & 13.9 & 2.86 & 1.3 & 1.80 & 21 & 0.82 & 0.7 & 0.2 & 0.031 & 0.128 \\
\hline $724 \mathrm{C}-4 \mathrm{H}-04,15-17 \mathrm{~cm}$ & 26.35 & & 12. & 2.5 & 1.2 & 1.5 & & $0.8-1-1-1-10$ & & & 0.025 & 0.138 \\
\hline $724 \mathrm{C}-4 \mathrm{H}-04,35-37 \mathrm{~cm}$ & 26.55 & 3 & 10. & 2.1 & 1.0 & 1.2 & ? & 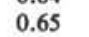 & 0.59 & $0.1 \quad-1$ & 0.024 & 0.139 \\
\hline $724 \mathrm{C}-4 \mathrm{H}-04,55-57 \mathrm{~cm}$ & 26.75 & 3.4 & 10. & 2.26 & 1. & 1.4. & & 0.7 r l & & & 0.0 & 0.173 \\
\hline $724 \mathrm{C}-4 \mathrm{H}-04,75-77 \mathrm{~cm}$ & 26.95 & 3 & 11.0 & 2.2 & 1.0 & 1.3 & 24.1 & 0.7 & 0. & 0.1 & 0.024 & 0.127 \\
\hline $724 \mathrm{C}-4 \mathrm{H}-04,95-97 \mathrm{~cm}$ & 27.15 & .8 & 11.9 & 2.29 & 0. & 1.3 & & 0.7 & & & & 0.142 \\
\hline $724 \mathrm{C}-4 \mathrm{H}-04,115-117 \mathrm{~cm}$ & 27.35 & 320 . & 11.9 & 2.3 & 1.1 & 1.4. & & 0.7 & 0. & 0.197 & 0.025 & 0.194 \\
\hline $724 \mathrm{C}-4 \mathrm{H}-04,135-137 \mathrm{~cm}$ & 27.55 & 322.2 & 10.73 & 2.20 & 1.04 & 1.36 & & 0.80 & 0.60 & 8 & 0.025 & 0.271 \\
\hline $724 \mathrm{C}-4 \mathrm{H}-05,05-07 \mathrm{~cm}$ & 27.7 & 324.4 & 10.5 & 2.12 & 009 & 1.2 & 18 & 07 & 0.5 & 0.171 & 0.023 & 0.533 \\
\hline $724 \mathrm{C}-4 \mathrm{H}-05,25-27 \mathrm{~cm}$ & 27.95 & 326.6 & 8.26 & 1.33 & 0.86 & 1.19 & & 0. & & 1 & 0.022 & 0.272 \\
\hline $724 \mathrm{C}-4 \mathrm{H}-05,45-47 \mathrm{~cm}$ & & 328 & 11.6 & 2.1 & 10 & 1.5 & & 0.7 & 0.6 & 0.192 & 0.026 & 0140 \\
\hline $724 \mathrm{C}-4 \mathrm{H}-05,65-67 \mathrm{~cm}$ & 28.35 & 0 & 12.65 & 2.42 & 1. & 1.72 & & 0.80 & 0.66 & 0 & 0.032 & 0.100 \\
\hline $724 \mathrm{C}-4 \mathrm{H}-05,85-87 \mathrm{~cm}$ & 28.5 & 3 & 11.54 & 2.29 & 1.0 & 1.6 & 20 & 0.7 & 0.63 & 0.191 & 0.030 & 0.099 \\
\hline $724 \mathrm{C}-4 \mathrm{H}-05,105-107 \mathrm{~cm}$ & 28.75 & 334.3 & 12.04 & 2.46 & 1.23 & 1.92 & 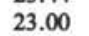 & 0.6 & 0.67 & 7 & 0.031 & 0.066 \\
\hline $724 \mathrm{C}-4 \mathrm{H}-05,125-127 \mathrm{~cm}$ & 28.9 & 336.0 & 11.44 & 2.32 & 1.11 & 1.7 & 28 & 0.7 & 0.6 & 0.189 & 0.026 & 0.102 \\
\hline $724 \mathrm{C}-4 \mathrm{H}-05,145-147 \mathrm{~cm}$ & 29.15 & 33 & 12. & 2.51 & 1.26 & 1.98 & 4 & 0.65 & 0.70 & 0.208 & 0.032 & 0.048 \\
\hline $724 \mathrm{C}-4 \mathrm{H}-06,15-17 \mathrm{~cm}$ & & & 12.74 & 2.56 & 1.2 & & & 0.7 & 0.73 & 0.214 & 0.033 & 0.054 \\
\hline $724 \mathrm{C}-4 \mathrm{H}-06,35-37 \mathrm{~cm}$ & 29.55 & 341.0 & 13.84 & 2.69 & 1.37 & 2.04 & 20.77 & 0.81 & 0.79 & 0.226 & 0.033 & 0.054 \\
\hline $724 \mathrm{C}-4 \mathrm{H}-06,55-57 \mathrm{~cm}$ & & & & 2.72 & & & & 0.8 & 0.78 & 0.224 & 0.034 & 0.054 \\
\hline $724 \mathrm{C}-4 \mathrm{H}-06,75-77 \mathrm{~cm}$ & & 344.3 & & 2.73 & 1.32 & & 20. & 0.8 & 0.79 & 0.232 & 0.035 & 0.056 \\
\hline $724 \mathrm{C}-4 \mathrm{H}-06,95-97 \mathrm{~cm}$ & & 346.0 & 15. & 2.93 & 1.43 & & 19.60 & 0.5 & 0.8 & 0.239 & 0.036 & 0.065 \\
\hline $724 \mathrm{C}-4 \mathrm{H}-06,115-117 \mathrm{~cm}$ & 30.35 & 345 & 14. & 2.8 & 1.45 & & & 0.5 & 0.8 & 0.239 & 0.036 & 0.069 \\
\hline $724 \mathrm{C}-4 \mathrm{H}-06,135-137 \mathrm{~cm}$ & 30.55 & 352 & & 2.8 & 1.42 & 1.5 & & 0.8 & 0.80 & 0.238 & 0.034 & 0.077 \\
\hline $724 \mathrm{C}-4 \mathrm{H}-07,15-17 \mathrm{~cm}$ & 30.85 & 355.6 & 13.76 & 2.78 & 1.52 & 1.96 & 20.31 & 0.80 & 0.80 & 0.239 & 0.031 & 0.086 \\
\hline
\end{tabular}


Appendic C (continued).

\begin{tabular}{|c|c|c|c|c|c|c|c|c|c|c|c|c|}
\hline $\begin{array}{c}\text { Sample } \\
\text { identification }\end{array}$ & $\begin{array}{l}\text { Depth } \\
\text { (mbsf) }\end{array}$ & $\begin{array}{l}{ }^{\text {a Age }} \\
\text { (k.y.) }\end{array}$ & $\underset{\text { (wt } \% \text { ) }}{\mathrm{Si}}$ & $\underset{(w t \%)}{A l}$ & $\underset{(w t \%)}{\mathrm{Fe}}$ & $\underset{(w t \%)}{\mathrm{Mg}}$ & $\underset{(w t \%)}{\mathrm{Ca}}$ & $\underset{(w t \%)}{\mathrm{Na}}$ & $\underset{(w t \%)}{K}$ & $\underset{\text { (wt } \%)}{\mathrm{Ti}}$ & $\underset{(w t \%)}{\mathrm{Mn}}$ & $\underset{(w t \%)}{P}$ \\
\hline $724 \mathrm{C}-4 \mathrm{H}-07,35-37 \mathrm{~cm}$ & 31.05 & - & 14.39 & 2.86 & 1.43 & 2.00 & 19.29 & 0.84 & 0.82 & 0.239 & 0.036 & 0.081 \\
\hline $724 \mathrm{C}-4 \mathrm{H}-07,55-57 \mathrm{~cm}$ & 31.25 & - & 12.86 & 2.61 & 1.39 & 1.81 & 20.80 & 0.74 & 0.75 & 0.218 & 0.031 & 0.128 \\
\hline $724 \mathrm{C}-4 \mathrm{H}-07,75-77 \mathrm{~cm}$ & 31.46 & - & 12.93 & 2.69 & 1.39 & 1.94 & 20.73 & 0.76 & 0.76 & 0.224 & 0.029 & 0.079 \\
\hline $724 \mathrm{C}-5 \mathrm{H}-01,10-12 \mathrm{~cm}$ & 31.30 & - & 12.27 & 2.54 & 1.27 & 1.85 & 22.13 & 0.80 & 0.72 & 0.209 & 0.033 & 0.098 \\
\hline $724 \mathrm{C}-5 \mathrm{H}-01,25-27 \mathrm{~cm}$ & 31.45 & - & 12.30 & 2.44 & 1.16 & 1.71 & 21.74 & 0.89 & 0.69 & 0.207 & 0.030 & 0.106 \\
\hline $724 \mathrm{C}-5 \mathrm{H}-01,45-47 \mathrm{~cm}$ & 31.65 & - & 12.36 & 2.40 & 1.13 & 1.57 & 22.70 & 0.79 & 0.68 & 0.208 & 0.032 & 0.113 \\
\hline $724 \mathrm{C}-5 \mathrm{H}-01,65-67 \mathrm{~cm}$ & 31.85 & - & 12.43 & 2.37 & 1.10 & 1.51 & 22.50 & 0.76 & 0.66 & 0.212 & 0.031 & 0.180 \\
\hline $724 \mathrm{C}-5 \mathrm{H}-01,85-87 \mathrm{~cm}$ & 32.05 & - & 12.75 & 2.40 & 1.09 & 1.59 & 22.12 & 0.82 & 0.67 & 0.215 & 0.032 & 0.224 \\
\hline $724 \mathrm{C}-5 \mathrm{H}-01,105-107 \mathrm{~cm}$ & 32.25 & - & 12.87 & 2.38 & 1.10 & 1.47 & 22.25 & 0.82 & 0.66 & 0.210 & 0.027 & 0.305 \\
\hline $724 \mathrm{C}-5 \mathrm{H}-01,125-127 \mathrm{~cm}$ & 32.45 & - & 12.48 & 2.33 & 1.05 & 1.40 & 21.03 & 0.82 & 0.65 & 0.202 & 0.027 & 0.347 \\
\hline $724 \mathrm{C}-5 \mathrm{H}-01,145-147 \mathrm{~cm}$ & 32.65 & - & 12.92 & 2.35 & 1.00 & 1.50 & 21.85 & 0.96 & 0.65 & 0.197 & 0.028 & 0.930 \\
\hline $724 \mathrm{C}-5 \mathrm{H}-02,15-17 \mathrm{~cm}$ & 32.85 & - & 13.05 & 2.42 & 1.04 & 1.71 & 21.86 & 0.89 & 0.66 & 0.210 & 0.031 & 0.258 \\
\hline $724 \mathrm{C}-5 \mathrm{H}-02,35-37 \mathrm{~cm}$ & 33.05 & - & 13.60 & 2.50 & 1.08 & 1.86 & 21.31 & 0.86 & 0.70 & 0.216 & 0.032 & 0.144 \\
\hline $724 \mathrm{C}-5 \mathrm{H}-02,55-57 \mathrm{~cm}$ & 33.25 & - & 12.49 & 2.52 & 1.24 & 2.07 & 20.75 & 0.84 & 0.71 & 0.209 & 0.031 & 0.354 \\
\hline $724 \mathrm{C}-5 \mathrm{H}-02,75-77 \mathrm{~cm}$ & 33.45 & - & 13.84 & 2.56 & 1.21 & 1.98 & 18.85 & 0.92 & 0.73 & 0.226 & 0.032 & 0.186 \\
\hline $724 \mathrm{C}-5 \mathrm{H}-02,95-97 \mathrm{~cm}$ & 33.65 & - & 15.45 & 2.82 & 1.38 & 2.12 & 19.20 & 0.86 & 0.81 & 0.250 & 0.038 & 0.057 \\
\hline $724 \mathrm{C}-5 \mathrm{H}-02,115-117 \mathrm{~cm}$ & 33.85 & - & 11.41 & 2.41 & 1.28 & 2.04 & 22.32 & 0.68 & 0.68 & 0.207 & 0.035 & 0.131 \\
\hline $724 \mathrm{C}-5 \mathrm{H}-02,135-137 \mathrm{~cm}$ & 34.05 & - & 11.68 & 2.49 & 1.34 & 2.07 & 22.62 & 0.80 & 0.70 & 0.215 & 0.037 & 0.068 \\
\hline $724 \mathrm{C}-5 \mathrm{H}-03,05-07 \mathrm{~cm}$ & 34.25 & - & 12.45 & 2.76 & 1.44 & 2.17 & 19.99 & 0.78 & 0.77 & 0.227 & 0.031 & 0.174 \\
\hline $724 \mathrm{C}-5 \mathrm{H}-03,25-27 \mathrm{~cm}$ & 34.45 & - & 13.56 & 2.70 & 1.36 & 2.15 & 19.79 & 0.81 & 0.76 & 0.228 & 0.035 & 0.092 \\
\hline $724 \mathrm{C}-5 \mathrm{H}-03,45-47 \mathrm{~cm}$ & 34.65 & - & 13.60 & 2.73 & 1.38 & 2.28 & 20.24 & 0.98 & 0.77 & 0.236 & 0.037 & 0.071 \\
\hline $724 \mathrm{C}-5 \mathrm{H}-03,65-67 \mathrm{~cm}$ & 34.85 & - & 13.59 & 2.76 & 1.41 & 2.12 & 20.56 & 0.84 & 0.77 & 0.232 & 0.038 & 0.103 \\
\hline $724 \mathrm{C}-5 \mathrm{H}-03,85-87 \mathrm{~cm}$ & 35.05 & - & 12.60 & 2.70 & 1.53 & 2.17 & 21.15 & 0.69 & 0.76 & 0.226 & 0.037 & 0.071 \\
\hline $724 \mathrm{C}-5 \mathrm{H}-03,105-107 \mathrm{~cm}$ & 35.25 & - & 12.94 & 2.65 & 1.41 & 2.02 & 21.35 & 0.85 & 0.74 & 0.219 & 0.034 & 0.117 \\
\hline $724 \mathrm{C}-5 \mathrm{H}-03,125-127 \mathrm{~cm}$ & 35.45 & - & 12.52 & 2.59 & 1.39 & 1.94 & 21.34 & 0.80 & 0.74 & 0.220 & 0.037 & 0.111 \\
\hline $724 \mathrm{C}-5 \mathrm{H}-03,145-147 \mathrm{~cm}$ & 35.65 & - & 13.07 & 2.65 & 1.34 & 1.89 & 21.58 & 0.79 & 0.73 & 0.223 & 0.031 & 0.101 \\
\hline $724 \mathrm{C}-5 \mathrm{H}-04,15-17 \mathrm{~cm}$ & 35.85 & - & 13.04 & 2.55 & 1.20 & 1.63 & 21.99 & 0.90 & 0.70 & 0.216 & 0.031 & 0.168 \\
\hline $724 \mathrm{C}-5 \mathrm{H}-04,35-37 \mathrm{~cm}$ & 36.05 & - & 13.21 & 2.54 & 1.17 & 1.50 & 22.01 & 0.82 & 0.69 & 0.216 & 0.030 & 0.268 \\
\hline $724 \mathrm{C}-5 \mathrm{H}-04,55-57 \mathrm{~cm}$ & 36.25 & - & 12.62 & 2.47 & 1.10 & 1.50 & 22.10 & 0.88 & 0.65 & 0.203 & 0.029 & 0.312 \\
\hline $724 \mathrm{C}-5 \mathrm{H}-04,75-77 \mathrm{~cm}$ & 36.45 & - & 11.98 & 2.23 & 0.89 & 1.40 & 22.68 . & 0.92 & 0.59 & 0.184 & 0.025 & 0.807 \\
\hline $724 \mathrm{C}-5 \mathrm{H}-04,95-97 \mathrm{~cm}$ & 36.65 & - & 11.87 & 2.27 & 0.99 & 1.32 & 23.16 & 0.90 & 0.60 & 0.187 & 0.026 & 0.176 \\
\hline $724 \mathrm{C}-5 \mathrm{H}-04,115-117 \mathrm{~cm}$ & 36.85 & - & 11.07 & 2.13 & 0.91 & 1.18 & 24.12 & 0.82 & 0.56 & 0.176 & 0.025 & 0.241 \\
\hline $724 \mathrm{C}-5 \mathrm{H}-04,135-137 \mathrm{~cm}$ & 37.05 & - & 9.73 & 1.89 & 0.81 & 0.90 & 26.04 & 0.75 & 0.50 & 0.152 & 0.021 & 0.182 \\
\hline $724 \mathrm{C}-5 \mathrm{H}-05,05-07 \mathrm{~cm}$ & 37.25 & - & 11.80 & 2.27 & 0.99 & 1.26 & 23.27 & 0.93 & 0.61 & 0.185 & 0.028 & 0.250 \\
\hline $724 \mathrm{C}-5 \mathrm{H}-05,25-27 \mathrm{~cm}$ & 37.45 & - & 12.13 & 2.30 & 1.00 & 1.31 & 23.13 & 0.78 & 0.62 & 0.191 & 0.027 & 0.206 \\
\hline $724 \mathrm{C}-5 \mathrm{H}-05,45-47 \mathrm{~cm}$ & 37.65 & - & 12.40 & 2.43 & 1.11 & 1.45 & 22.55 & 0.96 & 0.66 & 0.199 & 0.029 & 0.194 \\
\hline $724 \mathrm{C}-5 \mathrm{H}-05,65-67 \mathrm{~cm}$ & 37.85 & - & 12.60 & 2.33 & 0.97 & 1.23 & 22.07 & 0.88 & 0.62 & 0.196 & 0.031 & 0.155 \\
\hline $724 \mathrm{C}-5 \mathrm{H}-05,85-87 \mathrm{~cm}$ & 38.05 & - & 13.39 & 2.50 & 1.07 & 1.46 & 2168 & 0.95 & 0.67 & 0.211 & 0.029 & 0.173 \\
\hline $724 \mathrm{C}-5 \mathrm{H}-05,105-107 \mathrm{~cm}$ & 38.25 & - & 13.26 & 2.51 & 1.10 & 1.45 & 21.38 & 0.89 & 0.67 & 0.213 & 0.031 & 0.177 \\
\hline $724 \mathrm{C}-5 \mathrm{H}-05,125-127 \mathrm{~cm}$ & 38.45 & - & 13.80 & 2.66 & 1.26 & 1.76 & 20.53 & 0.95 & 0.71 & 0.232 & 0.031 & 0.145 \\
\hline $724 \mathrm{C}-5 \mathrm{H}-05,145-147 \mathrm{~cm}$ & 38.65 & - & 13.58 & 2.60 & 1.25 & 1.60 & 21.20 & 0.86 & 0.69 & 0.225 & 0.026 & 0.391 \\
\hline $724 \mathrm{C}-5 \mathrm{H}-06,15-17 \mathrm{~cm}$ & 38.85 & - & 12.84 & 2.48 & 1.10 & 1.47 & 22.38 & 0.83 & 0.66 & 0.204 & 0.031 & 0.202 \\
\hline $724 \mathrm{C}-5 \mathrm{H}-06,35-37 \mathrm{~cm}$ & 39.05 & - & 12.74 & 2.41 & 1.10 & 1.44 & 22.19 & 0.87 & 0.64 & 0.206 & 0.031 & 0.233 \\
\hline $724 \mathrm{C}-5 \mathrm{H}-06,55-57 \mathrm{~cm}$ & 39.25 & - & 12.57 & 2.38 & 1.06 & 1.43 & 22.40 & 0.77 & 0.63 & 0.194 & 0.032 & 0.200 \\
\hline $724 \mathrm{C}-5 \mathrm{H}-06,75-77 \mathrm{~cm}$ & 39.45 & - & 12.42 & 2.48 & 1.19 & 1.58 & 21.77 & 0.90 & 0.66 & 0.206 & 0.031 & 0.165 \\
\hline $724 \mathrm{C}-5 \mathrm{H}-06,95-97 \mathrm{~cm}$ & 39.65 & - & 12.20 & 2.41 & 1.13 & 1.49 & 22.38 & 0.80 & 0.65 & 0.201 & 0.030 & 0.169 \\
\hline $724 \mathrm{C}-5 \mathrm{H}-06,115-117 \mathrm{~cm}$ & 39.85 & - & 12.04 & 2.45 & 1.17 & 1.65 & 22.22 & 0.70 & 0.66 & 0.202 & 0.033 & 0.155 \\
\hline $724 \mathrm{C}-5 \mathrm{H}-06,135-137 \mathrm{~cm}$ & 40.05 & - & 12.68 & 2.45 & 1.11 & 1.58 & 21.86 & 0.95 & 0.66 & 0.211 & 0.030 & 0.152 \\
\hline $724 \mathrm{C}-5 \mathrm{H}-07,05-07 \mathrm{~cm}$ & 40.25 & - & 11.60 & 2.34 & 1.17 & 1.70 & 22.86 & 0.79 & 0.63 & 0.199 & 0.029 & 0.291 \\
\hline $724 \mathrm{C}-5 \mathrm{H}-07,25-27 \mathrm{~cm}$ & 40.45 & - & 12.94 & 2.71 & 1.43 & 2.09 & 20.88 & 0.85 & 0.74 & 0.231 & 0.036 & 0.141 \\
\hline $724 \mathrm{C}-5 \mathrm{H}-07,45-47 \mathrm{~cm}$ & 40.65 & - & 13.21 & 2.77 & 1.46 & 2.05 & 20.52 & 0.91 & 0.77 & 0.230 & 0.036 & 0.143 \\
\hline $724 \mathrm{C}-5 \mathrm{H}-07,60-62 \mathrm{~cm}$ & 40.80 & - & 12.92 & 2.64 & 1.34 & 1.88 & 20.74 & 0.89 & 0.72 & 0.223 & 0.034 & 0.141 \\
\hline $724 \mathrm{C}-6 \mathrm{X}-01,05-07 \mathrm{~cm}$ & 40.85 & - & 10.62 & 2.34 & 1.22 & 1.39 & 23.34 & 0.81 & 0.61 & 0.187 & 0.027 & 0.218 \\
\hline $724 C-6 X-01,25-27 \mathrm{~cm}$ & 41.05 & - & 10.01 & 2.28 & 1.20 & 1.39 & 23.86 & 0.71 & 0.60 & 0.186 & 0.025 & 0.171 \\
\hline $724 \mathrm{C}-6 \mathrm{X}-01,45-47 \mathrm{~cm}$ & 41.25 & - & 9.45 & 2.02 & 1.02 & 1.27 & 25.18 & 0.73 & 0.55 & 0.172 & 0.026 & 0.167 \\
\hline $724 C-6 X-01,65-67 \mathrm{~cm}$ & 41.45 & - & 10.23 & 2.34 & 1.27 & 1.76 & 23.95 & 0.73 & 0.65 & 0.194 & 0.031 & 0.094 \\
\hline $724 \mathrm{C}-6 \mathrm{X}-01,85-87 \mathrm{~cm}$ & 41.65 & - & 11.55 & 2.59 & 1.35 & 1.93 & 22.69 & 0.83 & 0.71 & 0.214 & 0.033 & 0.078 \\
\hline $724 \mathrm{C}-6 \mathrm{X}-01,105-107 \mathrm{~cm}$ & 41.85 & - & 10.79 & 2.46 & 1.33 & 1.83 & 23.14 & 0.75 & 0.67 & 0.206 & 0.030 & 0.082 \\
\hline $724 \mathrm{C}-6 \mathrm{X}-01,125-127 \mathrm{~cm}$ & 42.05 & - & 11.78 & 2.48 & 1.31 & 1.70 & 22.04 & 0.76 & 0.69 & 0.215 & 0.030 & 0.115 \\
\hline $724 \mathrm{C}-6 \mathrm{X}-01,145-147 \mathrm{~cm}$ & 42.25 & - & 14.60 & 3.04 & 1.60 & 2.24 & 26.46 & 1.00 & 0.84 & 0.252 & 0.038 & 0.166 \\
\hline $724 \mathrm{C}-6 \mathrm{X}-02,15-17 \mathrm{~cm}$ & 42.45 & - & 11.49 & 2.30 & 1.12 & 1.42 & 23.25 & 0.73 & 0.63 & 0.198 & 0.027 & 0.135 \\
\hline $724 \mathrm{C}-6 \mathrm{X}-02,35-37 \mathrm{~cm}$ & 42.65 & - & 12.03 & 2.45 & 1.25 & 1.63 & 21.41 & 0.73 & 0.67 & 0.209 & 0.028 & 0.181 \\
\hline $724 \mathrm{C}-6 \mathrm{X}-02,55-57 \mathrm{~cm}$ & 42.85 & - & 12.17 & 2.38 & 1.20 & 1.66 & 22.18 & 0.74 & 0.67 & 0.215 & 0.029 & 0.113 \\
\hline $724 C-6 \times-02,75-77 \mathrm{~cm}$ & 43.05 & - & 13.61 & 2.68 & 1.38 & 2.03 & 20.58 & 0.91 & 0.75 & 0.244 & 0.034 & 0.113 \\
\hline $724 C-6 X-02,95-97 \mathrm{~cm}$ & 43.25 & - & 14.49 & 2.81 & 1.44 & 2.17 & 19.57 & 0.85 & 0.80 & 0.264 & 0.035 & 0.088 \\
\hline $724 \mathrm{C}-6 \mathrm{X}-02,115-117 \mathrm{~cm}$ & 43.45 & - & 14.12 & 2.83 & 1.50 & 2.21 & 19.59 & 0.88 & 0.80 & 0.256 & 0.033 & 0.106 \\
\hline $724 C-6 \times-02,135-137 \mathrm{~cm}$ & 43.65 & - & 14.41 & 2.90 & 1.50 & 2.31 & 19.05 & 0.82 & 0.81 & 0.255 & 0.034 & 0.092 \\
\hline $724 \mathrm{C}-6 \mathrm{X}-03,05-07 \mathrm{~cm}$ & 43.8 & - & 15.65 & 3.07 & 1.59 & 2.47 & 18.02 & 0.98 & 0.87 & 0.267 & 0.037 & 0.069 \\
\hline $724 \mathrm{C}-6 \mathrm{X}-03,25-27 \mathrm{~cm}$ & 44.05 & - & 14.57 & 2.94 & 1.55 & 2.33 & 18.82 & 0.92 & 0.83 & 0.254 & 0.038 & 0.083 \\
\hline $724 \mathrm{C}-6 \mathrm{X}-03,45-47 \mathrm{~cm}$ & 44.2 & - & 14.60 & 2.93 & 1.53 & 2.35 & 18.72 & 0.93 & 0.83 & 0.266 & 0.038 & 0.087 \\
\hline $724 \mathrm{C}-6 \mathrm{X}-03,65-67 \mathrm{~cm}$ & 44.45 & - & 13.94 & 2.96 & 1.62 & 2.61 & 18.62 & 0.86 & 0.84 & 0.246 & 0.038 & 0.078 \\
\hline $724 \mathrm{C}-6 \mathrm{X}-03,85-87 \mathrm{~cm}$ & 44.6 & - & 14.19 & 3.02 & 1.65 & 2.69 & 18.52 & 0.85 & 0.86 & 0.246 & 0.038 & 0.088 \\
\hline $724 \mathrm{C}-6 \mathrm{X}-03,105-107 \mathrm{~cm}$ & 44.85 & - & 13.7 & 2.91 & 1.57 & 2.47 & 19.14 & 0.83 & 0.82 & 0.237 & 0.036 & 0.098 \\
\hline $724 \mathrm{C}-6 \mathrm{X}-03,125-127 \mathrm{~cm}$ & 45.05 & - & 13. & 3.02 & 1.71 & 2.6 & 18.51 & 0.92 & 0.85 & 0.246 & 0.040 & 0.085 \\
\hline $724 \mathrm{C}-6 \mathrm{X}-03,145-147 \mathrm{~cm}$ & 45.25 & - & 15.10 & 3.1 & 1.67 & 2.5 & 18.27 & 0.86 & 0.89 & 0.257 & 0.041 & 0.079 \\
\hline $724 \mathrm{C}-6 \mathrm{X}-04,15-17 \mathrm{~cm}$ & 45.45 & - & 14.38 & 3.10 & 1.73 & 2. & 18.20 & 0.80 & 0.88 & 0.251 & 0.038 & 0.075 \\
\hline $724 C-6 \times-04,35-37 \mathrm{~cm}$ & 45.65 & - & 13. & 3.0 & 1.7 & 2. & 18.97 & 0.78 & 0.86 & 0.243 & 0.037 & 0.091 \\
\hline 72 & 45.85 & & 13.80 & 13 & 1 & 2.44 & 55 & & 18 & 17 & 0.036 & \\
\hline
\end{tabular}


Appendic C (continued).

\begin{tabular}{|c|c|c|c|c|c|c|c|c|c|c|c|c|}
\hline $\begin{array}{c}\text { Sample } \\
\text { identification }\end{array}$ & $\begin{array}{l}\text { Depth } \\
\text { (mbsf) }\end{array}$ & $\begin{array}{l}\text { a Age } \\
\text { (k.y.) }\end{array}$ & $\underset{(w t \%)}{\mathrm{Si}}$ & $\underset{(w t \%)}{A l}$ & $\underset{(w t \%)}{\mathrm{Fe}}$ & $\underset{(w t \%)}{\mathrm{Mg}}$ & $\underset{(w t \%)}{\mathrm{Ca}}$ & $\underset{(w t \%)}{\mathrm{Na}}$ & $\underset{\text { (wt } \%)}{K}$ & $\underset{\text { (wt } \% \text { ) }}{\mathrm{Ti}}$ & $\underset{(w t \%)}{M n}$ & $\underset{(w t \%)}{P}$ \\
\hline $724 \mathrm{C}-6 \mathrm{X}-04,75-77 \mathrm{~cm}$ & 46.05 & - & 13.04 & 2.93 & 1.74 & 2.30 & 19.07 & 0.77 & 0.83 & 0.237 & 0.037 & 0.104 \\
\hline $724 C-6 X-04,95-97 \mathrm{~cm}$ & 46.25 & - & 13.60 & 2.98 & 1.69 & 2.36 & 19.03 & 0.77 & 0.84 & 0.243 & 0.037 & 0.095 \\
\hline $724 C-6 X-04,115-117 \mathrm{~cm}$ & 46.45 & - & 13.77 & 3.06 & 1.75 & 2.40 & 19.36 & 0.85 & 0.87 & 0.248 & 0.035 & 0.092 \\
\hline $724 C-6 X-04,135-137 \mathrm{~cm}$ & 46.65 & - & 13.29 & 2.95 & 1.69 & 2.46 & 19.66 & 0.87 & 0.84 & 0.241 & 0.036 & 0.091 \\
\hline $724 \mathrm{C}-6 \mathrm{X}-05,05-07 \mathrm{~cm}$ & 46.85 & - & 13.90 & 3.09 & 1.76 & 2.59 & 18.63 & 1.04 & 0.88 & 0.244 & 0.036 & 0.083 \\
\hline $724 \mathrm{C}-6 \mathrm{X}-05,25-27 \mathrm{~cm}$ & 47.05 & - & 13.53 & 3.15 & 1.80 & 2.40 & 19.03 & 0.66 & 0.89 & 0.255 & 0.039 & 0.077 \\
\hline $724 C-6 X-05,45-47 \mathrm{~cm}$ & 47.25 & - & 14.03 & 3.12 & 1.77 & 2.46 & 18.81 & 0.84 & 0.89 & 0.257 & 0.039 & 0.073 \\
\hline $724 C-6 X-05,65-67 \mathrm{~cm}$ & 47.45 & - & 15.49 & 3.34 & 1.76 & 2.50 & 18.54 & 0.97 & 0.92 & 0.260 & 0.040 & 0.066 \\
\hline $724 C-6 X-05,85-87 \mathrm{~cm}$ & 47.65 & - & 14.62 & 3.24 & 1.82 & 2.51 & 18.83 & 0.80 & 0.91 & 0.263 & 0.038 & 0.074 \\
\hline $724 \mathrm{C}-6 \mathrm{X}-05,105-107 \mathrm{~cm}$ & 47.85 & - & 14.96 & 3.27 & 1.84 & 2.49 & 18.24 & 0.89 & 0.92 & 0.270 & 0.043 & 0.067 \\
\hline $724 \mathrm{C}-6 \mathrm{X}-05,125-127 \mathrm{~cm}$ & 48.05 & - & 15.27 & 3.30 & 1.83 & 2.38 & 17.97 & 0.95 & 0.92 & 0.270 & 0.045 & 0.070 \\
\hline $724 \mathrm{C}-6 \mathrm{X}-05,145-147 \mathrm{~cm}$ & 48.25 & - & 14.95 & 3.24 & 1.86 & 2.44 & 17.89 & 0.89 & 0.90 & 0.273 & 0.044 & 0.068 \\
\hline $724 \mathrm{C}-6 \mathrm{X}-06,15-17 \mathrm{~cm}$ & 48.45 & - & 14.39 & 3.19 & 1.77 & 2.27 & 18.28 & 0.79 & 0.88 & 0.261 & 0.039 & 0.076 \\
\hline $724 \mathrm{C}-6 \mathrm{X}-06,35-37 \mathrm{~cm}$ & 48.65 & - & 14.85 & 3.36 & 2.03 & 2.43 & 18.16 & 0.86 & 0.94 & 0.267 & 0.042 & 0.072 \\
\hline $724 \mathrm{C}-6 \mathrm{X}-06,55-57 \mathrm{~cm}$ & 48.85 & - & 15.87 & 3.63 & 2.04 & 2.54 & 15.40 & 1.01 & 1.00 & 0.292 & 0.036 & 0.101 \\
\hline $724 \mathrm{C}-6 \mathrm{X}-06,75-77 \mathrm{~cm}$ & 49.05 & - & 15.61 & 3.38 & 1.87 & 2.14 & 17.87 & 0.69 & 0.94 & 0.268 & 0.044 & 0.067 \\
\hline $724 \mathrm{C}-6 \mathrm{X}-06,95-97 \mathrm{~cm}$ & 49.25 & - & 11.66 & 2.54 & 1.33 & 1.90 & 21.72 & 0.79 & 0.70 & 0.211 & 0.029 & 0.114 \\
\hline $724 C-7 X-01,25-27 \mathrm{~cm}$ & 50.75 & - & 15.67 & 3.33 & 1.94 & 2.37 & 17.76 & 0.93 & 0.94 & 0.274 & 0.043 & 0.069 \\
\hline $724 C-7 X-01,65-67 \mathrm{~cm}$ & 51.15 & - & 11.22 & 2.48 & 1.30 & 2.08 & 22.04 & 0.67 & 0.70 & 0.205 & 0.029 & 0.157 \\
\hline $724 C-7 X-01,85-87 \mathrm{~cm}$ & 51.35 & - & 12.57 & 2.76 & 1.43 & 2.25 & 20.95 & 0.77 & 0.78 & 0.223 & 0.029 & 0.162 \\
\hline $724 \mathrm{C}-7 \mathrm{X}-01,105-107 \mathrm{~cm}$ & 51.55 & - & 11.97 & 2.79 & 1.54 & 2.55 & 19.74 & 0.69 & 0.81 & 0.221 & 0.035 & 0.081 \\
\hline $724 \mathrm{C}-7 \mathrm{X}-01,125-127 \mathrm{~cm}$ & 51.75 & - & 11.93 & 2.61 & 1.45 & 2.25 & 20.09 & 0.73 & 0.75 & 0.215 & 0.031 & 0.109 \\
\hline $724 \mathrm{C}-7 \mathrm{X}-02,15-17 \mathrm{~cm}$ & 52.15 & - & 13.11 & 2.91 & 1.61 & 2.60 & 19.96 & 0.75 & 0.84 & 0.239 & 0.043 & 0.062 \\
\hline $724 C-7 X-02,35-37 \mathrm{~cm}$ & 52.35 & - & 13.29 & 2.91 & 1.61 & 2.61 & 19.98 & 0.74 & 0.84 & 0.242 & 0.039 & 0.063 \\
\hline $724 \mathrm{C}-7 \mathrm{X}-02,55-57 \mathrm{~cm}$ & 52.55 & - & 13.00 & 2.84 & 1.52 & 2.36 & 20.12 & 0.89 & 0.81 & 0.235 & 0.038 & 0.084 \\
\hline $724 C-7 X-02,75-77 \mathrm{~cm}$ & 52.75 & - & 13.75 & 3.03 & 1.66 & 2.63 & 19.39 & 0.76 & 0.88 & 0.246 & 0.038 & 0.058 \\
\hline $724 \mathrm{C}-7 \mathrm{X}-02,115-117 \mathrm{~cm}$ & 53.15 & - & 13.55 & 2.94 & 1.58 & 2.44 & 19.79 & 0.85 & 0.84 & 0.241 & 0.034 & 0.071 \\
\hline $724 \mathrm{C}-7 \mathrm{X}-02,135-137 \mathrm{~cm}$ & 53.35 & - & 13.99 & 3.06 & 1.65 & 2.58 & 19.24 & 0.70 & 0.89 & 0.243 & 0.041 & 0.060 \\
\hline $724 \mathrm{C}-7 \mathrm{X}-03,05-07 \mathrm{~cm}$ & 53.55 & - & 14.08 & 3.03 & 1.65 & 2.58 & 18.99 & 0.82 & 0.89 & 0.252 & 0.036 & 0.061 \\
\hline $724 C-7 X-03,25-27 \mathrm{~cm}$ & 53.75 & - & 14.28 & 3.05 & 1.66 & 2.61 & 19.00 & 0.95 & 0.90 & 0.256 & 0.041 & 0.055 \\
\hline $724 \mathrm{C}-7 \mathrm{X}-03,65-67 \mathrm{~cm}$ & 54.15 & - & 13.95 & 3.02 & 1.57 & 2.27 & 19.57 & 0.58 & 0.85 & 0.245 & 0.039 & 0.077 \\
\hline $724 C-7 X-03,85-87 \mathrm{~cm}$ & 54.35 & - & 14.22 & 3.03 & 1.62 & 2.45 & 19.37 & 0.80 & 0.88 & 0.249 & 0.039 & 0.062 \\
\hline $724 \mathrm{C}-7 \mathrm{X}-03,105-107 \mathrm{~cm}$ & 54.55 & - & 13.62 & 2.94 & 1.55 & 2.61 & 19.26 & 1.08 & 0.85 & 0.243 & 0.035 & 0.063 \\
\hline $724 \mathrm{C}-7 \mathrm{X}-03,125-127 \mathrm{~cm}$ & 54.75 & - & 12.74 & 2.82 & 1.52 & 2.63 & 19.85 & 0.98 & 0.82 & 0.240 & 0.034 & 0.071 \\
\hline $724 \mathrm{C}-7 \mathrm{X}-04,15-17 \mathrm{~cm}$ & 55.15 & - & 12.49 & 2.64 & 1.44 & 2.15 & 20.84 & 0.75 & 0.75 & 0.224 & 0.030 & 0.188 \\
\hline $724 C-7 X-04,35-37 \mathrm{~cm}$ & 55.35 & - & 12.60 & 2.60 & 1.30 & 1.86 & 20.87 & 0.80 & 0.72 & 0.220 & 0.032 & 0.159 \\
\hline $724 \mathrm{C}-7 \mathrm{X}-04,55-57 \mathrm{~cm}$ & 55.55 & - & 11.92 & 2.49 & 1.25 & 1.74 & 21.75 & 0.87 & 0.69 & 0.208 & 0.027 & 0.115 \\
\hline $724 \mathrm{C}-7 \mathrm{X}-04,75-77 \mathrm{~cm}$ & 55.75 & - & 11.21 & 2.36 & 1.25 & 1.54 & 22.82 & 0.84 & 0.64 & 0.196 & 0.025 & 0.113 \\
\hline $724 \mathrm{C}-7 \mathrm{X}-04,115-117 \mathrm{~cm}$ & 56.15 & - & 10.99 & 2.27 & 1.12 & 1.55 & 23.13 & 0.71 & 0.63 & 0.188 & 0.029 & 0.117 \\
\hline $724 C-7 X-04,135-137 \mathrm{~cm}$ & 56.35 & - & 10.89 & 2.29 & 1.16 & 1.57 & 23.29 & 0.74 & 0.63 & 0.193 & 0.028 & 0.124 \\
\hline $724 \mathrm{C}-7 \mathrm{X}-05,05-07 \mathrm{~cm}$ & 56.55 & - & 11.27 & 2.56 & 1.39 & 1.94 & 22.05 & 0.76 & 0.72 & 0.202 & 0.030 & 0.130 \\
\hline $724 C-7 X-05,25-27 \mathrm{~cm}$ & 56.75 & - & 11.71 & 2.54 & 1.40 & 1.89 & 21.56 & 0.77 & 0.71 & 0.205 & 0.030 & 0.105 \\
\hline $724 \mathrm{C}-7 \mathrm{X}-05,65-67 \mathrm{~cm}$ & 57.15 & - & 10.95 & 2.26 & 1.13 & 1.54 & 22.35 & 0.68 & 0.63 & 0.191 & 0.029 & 0.111 \\
\hline $724 C-7 X-05,85-87 \mathrm{~cm}$ & 57.35 & - & 13.48 & 2.86 & 1.53 & 2.16 & 20.31 & 0.86 & 0.82 & 0.235 & 0.034 & 0.077 \\
\hline $724 \mathrm{C}-7 \mathrm{X}-05,105-107 \mathrm{~cm}$ & 57.55 & - & 12.31 & 2.62 & 1.35 & 1.93 & 20.98 & 0.78 & 0.73 & 0.215 & 0.031 & 0.103 \\
\hline $724 C-7 X-05,125-127 \mathrm{~cm}$ & 57.75 & - & 12.52 & 2.59 & 1.28 & 1.78 & 21.50 & 0.86 & 0.72 & 0.215 & 0.030 & 0.097 \\
\hline $724 C-7 X-06,15-17 \mathrm{~cm}$ & 58.15 & - & 11.78 & 2.23 & 1.06 & 1.24 & 23.66 & 0.80 & 0.61 & 0.194 & 0.030 & 0.089 \\
\hline $724 C-7 X-06,35-37 \mathrm{~cm}$ & 58.35 & - & 11.79 & 2.25 & 1.06 & 1.24 & 22.81 & 0.85 & 0.62 & 0.195 & 0.028 & 0.112 \\
\hline $724 C-7 X-06,55-57 \mathrm{~cm}$ & 58.55 & - & 10.95 & 2.35 & 1.20 & 1.36 & 23.02 & 0.81 & 0.63 & 0.194 & 0.029 & 0.115 \\
\hline $724 \mathrm{C}-7 \mathrm{X}-06,75-77 \mathrm{~cm}$ & 58.75 & - & 11.86 & 2.34 & 1.09 & 1.40 & 23.79 & 0.85 & 0.63 & 0.189 & 0.029 & 0.118 \\
\hline $724 \mathrm{C}-8 \mathrm{X}-01,05-07 \mathrm{~cm}$ & 60.25 & - & 9.45 & 2.10 & 1.06 & 1.16 & 24.85 & 0.68 & 0.56 & 0.172 & 0.028 & 0.132 \\
\hline $724 C-8 X-01,25-27 \mathrm{~cm}$ & 60.45 & - & 11.59 & 2.39 & 1.14 & 1.43 & 23.16 & 0.62 & 0.66 & 0.196 & 0.030 & 0.113 \\
\hline $724 \mathrm{C}-8 \mathrm{X}-01,65-67 \mathrm{~cm}$ & 60.85 & - & 10.42 & 2.30 & 1.18 & 1.41 & 23.50 & 0.75 & 0.62 & 0.188 & 0.025 & 0.124 \\
\hline $724 C-8 X-01,85-87 \mathrm{~cm}$ & 61.05 & - & 10.45 & 2.31 & 1.18 & 1.36 & 23.82 & 0.79 & 0.62 & 0.191 & 0.027 & 0.124 \\
\hline $724 \mathrm{C}-8 \mathrm{X}-01,105-107 \mathrm{~cm}$ & 61.25 & - & 11.14 & 2.37 & 1.16 & 1.41 & 23.24 & 0.74 & 0.64 & 0.194 & 0.028 & 0.102 \\
\hline $724 C-8 \mathrm{X}-01,125-127 \mathrm{~cm}$ & 61.45 & - & 11.08 & 2.39 & 1.23 & 1.62 & 22.86 & 0.94 & 0.65 & 0.196 & 0.029 & 0.148 \\
\hline $724 \mathrm{C}-8 \mathrm{X}-02,15-17 \mathrm{~cm}$ & 61.85 & - & 10.95 & 2.22 & 1.04 & 1.20 & 23.67 & 0.72 & 0.59 & 0.185 & 0.027 & 0.110 \\
\hline $724 \mathrm{C}-8 \mathrm{X}-02,35-37 \mathrm{~cm}$ & 62.05 & - & 11.70 & 2.54 & 1.31 & 1.60 & 22.18 & 0.78 & 0.69 & 0.205 & 0.031 & 0.108 \\
\hline $724 C-8 X-02,55-57 \mathrm{~cm}$ & 62.25 & - & 11.66 & 2.42 & 1.20 & 1.66 & 22.30 & 0.83 & 0.65 & 0.198 & 0.028 & 0.106 \\
\hline $724 \mathrm{C}-8 \mathrm{X}-02,75-77 \mathrm{~cm}$ & 62.45 & - & 10.81 & 2.32 & 1.21 & 1.51 & 22.58 & 0.74 & 0.63 & 0.192 & 0.030 & 0.134 \\
\hline $724 \mathrm{C}-8 \mathrm{X}-02,115-117 \mathrm{~cm}$ & 62.85 & - & 11.73 & 2.69 & 1.53 & 2.09 & 20.87 & 0.78 & 0.75 & 0.217 & 0.032 & 0.130 \\
\hline $724 \mathrm{C}-8 \mathrm{X}-02,135-137 \mathrm{~cm}$ & 63.05 & - & 13.61 & 3.08 & 1.85 & 2.56 & 19.19 & 0.87 & 0.87 & 0.245 & 0.040 & 0.086 \\
\hline $724 \mathrm{C}-8 \mathrm{X}-03,05-07 \mathrm{~cm}$ & 63.25 & - & 14.59 & 3.26 & 1.89 & 2.62 & 18.44 & 0.84 & 0.92 & 0.260 & 0.042 & 0.059 \\
\hline $724 C-8 X-03,25-27 \mathrm{~cm}$ & 63.45 & - & 14.57 & 3.24 & 1.90 & 2.57 & 18.18 & 0.77 & 0.92 & 0.264 & 0.045 & 0.055 \\
\hline $724 C-8 X-03,65-67 \mathrm{~cm}$ & 63.85 & - & 14.73 & 3.27 & 1.86 & 2.45 & 18.13 & 0.85 & 0.92 & 0.268 & 0.040 & 0.064 \\
\hline $724 \mathrm{C}-8 \mathrm{X}-03,85-87 \mathrm{~cm}$ & 64.05 & - & 14.90 & 3.19 & 1.81 & 2.41 & 18.45 & 0.84 & 0.87 & 0.269 & 0.043 & 0.062 \\
\hline $724 \mathrm{C}-8 \mathrm{X}-03,105-107 \mathrm{~cm}$ & 64.25 & - & 14.66 & 3.20 & 1.77 & 2.29 & 18.22 & 0.85 & 0.88 & 0.257 & 0.042 & 0.079 \\
\hline $724 \mathrm{C}-8 \mathrm{X}-03,125-127 \mathrm{~cm}$ & 64.45 & - & 14.75 & 3.17 & 1.80 & 2.35 & 18.38 & 0.90 & 0.86 & 0.270 & 0.040 & 0.082 \\
\hline $724 C-8 X-04,15-17 \mathrm{~cm}$ & 64.8 & - & 13.47 & 3.15 & 1.87 & 2.33 & 19.22 & 0.84 & 0.87 & 0.247 & 0.035 & 0.089 \\
\hline $724 C-8 X-04,35-37 \mathrm{~cm}$ & 65.05 & - & 14.14 & 3.24 & 1.84 & 2.27 & 18.78 & 0.91 & 0.87 & 0.257 & 0.040 & 0.090 \\
\hline $724 C-8 X-04,75-77 \mathrm{~cm}$ & 65.45 & - & 13.62 & 3.20 & 1.85 & 2.11 & 18.95 & 0.82 & 0.86 & 0.252 & 0.038 & 0.111 \\
\hline $724 \mathrm{C}-8 \mathrm{X}-04,95-97 \mathrm{~cm}$ & 65.65 & - & 11.90 & 2.88 & 1.68 & 1.83 & 21.18 & 0.82 & 0.77 & 0.221 & 0.031 & 0.122 \\
\hline $724 \mathrm{C}-8 \mathrm{X}-04,115-117 \mathrm{~cm}$ & 65.78 & - & 11.77 & 2.84 & 1.56 & 1.70 & 21.66 & 0.77 & 0.74 & 0.215 & 0.028 & 0.136 \\
\hline $724 C-8 X-04,135-137 \mathrm{~cm}$ & 66.05 & - & 10.72 & 2.61 & 1.52 & 1.68 & 20.46 & 0.83 & 0.69 & 0.205 & 0.028 & 0.159 \\
\hline $724 \mathrm{C}-8 \mathrm{X}-05,05-07 \mathrm{~cm}$ & 66.2 & - & 13.37 & 3.21 & 1.8 & 1.91 & 17.28 & 0.91 & 0.84 & 0.243 & 0.032 & 0.227 \\
\hline $724 \mathrm{C}-8 \mathrm{X}-05,25-27 \mathrm{~cm}$ & 66.45 & - & 12.23 & 2.99 & 1.76 & 1.87 & 19.84 & 0.86 & 0.77 & 0.229 & 0.032 & 0.162 \\
\hline $724 C-8 X-05,65-67 \mathrm{~cm}$ & 66.85 & - & 12.27 & 2.81 & 1.6 & 2.14 & 20.52 & 0.57 & 0.78 & 0.228 & 0.033 & 0.079 \\
\hline $724 \mathrm{C}-8 \mathrm{X}-05,85-87 \mathrm{~cm}$ & 67.05 & - & 9.09 & 2.13 & 1.23 & 1.74 & 25.20 & 0.75 & 0.58 & 0.175 & 0.027 & 0.098 \\
\hline
\end{tabular}


Appendic C (continued).

\begin{tabular}{|c|c|c|c|c|c|c|c|c|c|c|c|c|}
\hline $\begin{array}{c}\text { Sample } \\
\text { identification }\end{array}$ & $\begin{array}{l}\text { Depth } \\
\text { (mbsf) }\end{array}$ & $\begin{array}{l}{ }^{a} \text { Age } \\
\text { (k.y.) }\end{array}$ & $\underset{(w t \%)}{\mathrm{Si}}$ & $\begin{array}{c}\mathrm{Al} \\
(w t \%)\end{array}$ & $\underset{(w t \%)}{\mathrm{Fe}}$ & $\underset{(w t \%)}{\mathrm{Mg}}$ & $\underset{(w t \%)}{\mathrm{Ca}}$ & $\underset{(w t \%)}{\mathrm{Na}}$ & $\underset{(w t \%)}{K}$ & $\underset{(w t \%)}{\mathrm{Ti}}$ & $\underset{(w t \%)}{\operatorname{Mn}}$ & $\begin{array}{c}P \\
(w t \%)\end{array}$ \\
\hline $724 C-8 X-05,105-107 \mathrm{~cm}$ & 67.25 & - & 12.68 & 2.93 & 1.76 & 2.38 & 19.79 & 0.78 & 0.81 & 0.234 & 0.038 & 0.068 \\
\hline $724 C-8 X-05,125-127 \mathrm{~cm}$ & 67.45 & - & 12.99 & 2.99 & 1.75 & 2.34 & 19.92 & 0.73 & 0.82 & 0.246 & 0.036 & 0.072 \\
\hline $724 C-8 X-06,15-17 \mathrm{~cm}$ & 67.85 & - & 15.75 & 3.35 & 1.85 & 2.36 & 16.99 & 1.01 & 0.89 & 0.275 & 0.041 & 0.106 \\
\hline $724 C-8 X-06,35-37 \mathrm{~cm}$ & 68.05 & - & 12.46 & 2.99 & 1.74 & 2.12 & 19.80 & 0.96 & 0.82 & 0.232 & 0.031 & 0.100 \\
\hline $724 C-8 X-06,49-51 \mathrm{~cm}$ & 68.19 & - & 10.75 & 2.52 & 1.48 & 1.78 & 22.05 & 0.63 & 0.69 & 0.201 & 0.028 & 0.092 \\
\hline
\end{tabular}

- No data available.

a Chronostratigraphy from Zahn and Pedersen (this volume).

APPENDIX D

Elemental Statistics: Minimum, Average, and Maximum Values.

Hole $722 \mathrm{~B}$ major elements.

\begin{tabular}{lccccccc}
\hline & $\begin{array}{c}\mathrm{Si} \\
(w t \%)\end{array}$ & $\begin{array}{c}\mathrm{Al} \\
(w t \%)\end{array}$ & $\begin{array}{c}\mathrm{Fe} \\
(w t \%)\end{array}$ & $\begin{array}{c}\mathrm{Ca} \\
(w t \%)\end{array}$ & $\begin{array}{c}\mathrm{Ti} \\
(w t \%)\end{array}$ & $\begin{array}{c}\mathrm{Mn} \\
(w t \%)\end{array}$ & $\begin{array}{c}\mathrm{P} \\
(w t \%)\end{array}$ \\
\hline Min. & 4.48 & 1.11 & 0.70 & 21.40 & 0.07 & 0.02 & 0.03 \\
Avg. & 8.33 & 2.11 & 1.32 & 27.48 & 0.15 & 0.03 & 0.05 \\
Max. & 12.61 & 3.28 & 3.13 & 32.94 & 0.23 & 0.04 & 0.07 \\
\hline
\end{tabular}

Hole 722B trace elements.

\begin{tabular}{|c|c|c|c|c|c|c|c|c|c|c|c|c|c|c|}
\hline & $\begin{array}{c}\mathrm{Ni} \\
\text { (ppm) }\end{array}$ & $\underset{\text { (ppm) }}{\mathrm{Cr}}$ & $\begin{array}{c}\mathrm{V} \\
\text { (ppm) }\end{array}$ & $\underset{(\mathrm{ppm})}{\mathrm{Cu}}$ & $\underset{(\mathrm{ppm})}{\mathrm{Zn}}$ & $\underset{(\mathrm{ppm})}{\mathrm{Sr}}$ & $\begin{array}{c}\mathrm{Rb} \\
(\mathrm{ppm})\end{array}$ & $\underset{(\mathrm{ppm})}{\mathrm{Zr}}$ & $\underset{(\mathrm{ppm})}{\mathrm{Ba}}$ & $\underset{(\mathrm{ppm})}{\mathrm{Ce}}$ & $\begin{array}{c}\mathrm{Nd} \\
(\mathrm{ppm})\end{array}$ & $\begin{array}{c}\mathbf{Y} \\
(\mathrm{ppm})\end{array}$ & $\underset{(\mathrm{ppm})}{\mathrm{U}}$ & $\begin{array}{c}\text { Th } \\
\text { (ppm) }\end{array}$ \\
\hline Min. & 31 & 30 & 31 & 15 & 25 & 740 & 12 & 33 & 118 & 6 & 7 & 10 & 2 & 1 \\
\hline Avg. & 54 & 79 & 53 & 23 & 41 & 1064 & 26 & 62 & 380 & 23 & 16 & 14 & 3 & 2 \\
\hline Max. & 83 & 143 & 81 & 41 & 62 & 1489 & 41 & 94 & 1046 & 41 & 23 & 19 & 5 & 4 \\
\hline
\end{tabular}

Hole $724 \mathrm{C}$ major elements.

\begin{tabular}{lcccccccccc}
\hline & $\begin{array}{c}\mathrm{Si} \\
(w t \%)\end{array}$ & $\begin{array}{c}\mathrm{Al} \\
\left(w_{t} \%\right)\end{array}$ & $\begin{array}{c}\mathrm{Fe} \\
(w t \%)\end{array}$ & $\begin{array}{c}\mathrm{Mg} \\
(w t \%)\end{array}$ & $\begin{array}{c}\mathrm{Ca} \\
(w t \%)\end{array}$ & $\begin{array}{c}\mathrm{Na} \\
(w t \%)\end{array}$ & $\begin{array}{c}\mathrm{K} \\
(w t \%)\end{array}$ & $\begin{array}{c}\mathrm{Ti} \\
(w t \%)\end{array}$ & $\begin{array}{c}\mathrm{Mn} \\
(w t \%)\end{array}$ & $\begin{array}{c}\mathrm{P} \\
(w t \%)\end{array}$ \\
\hline Min. & 6.85 & 1.33 & 0.79 & 0.90 & 12.15 & 0.22 & 0.41 & 0.13 & 0.02 & 0.05 \\
Avg. & 13.20 & 2.75 & 1.44 & 1.98 & 20.65 & 0.83 & 0.76 & 0.23 & 0.03 & 0.12 \\
Max. & 19.84 & 4.22 & 2.34 & 3.25 & 28.27 & 1.27 & 1.17 & 0.33 & 0.05 & 0.93 \\
\hline
\end{tabular}

